\author{
UNIVERSIDADE DE BRASÍLIA \\ INSTITUTO DE PSICOLOGIA \\ PROGRAMA DE PÓS-GRADUAÇÃO DE PSICOLOGIA
}

ANDRÉ MAGALHÃES TEIXEIRA

\title{
AS ORIGENS DA PULSÃO E A INVENÇÃO DO HUMANO
}

Brasília 


\section{ANDRÉ MAGALHÃES TEIXEIRA}

\section{AS ORIGENS DA PULSÃO E A INVENÇÃO DO HUMANO}

Tese apresentada como requisito para obtenção do título de Doutor em Psicologia Clínica e Cultura pela Universidade de Brasília - UnB

Brasília 


\section{AS ORIGENS DA PULSÃO E A INVENÇÃO DO HUMANO}

Tese apresentada como requisito para a obtenção do título de Doutor em Psicologia Clínica e Cultura pela Universidade de Brasília - UnB

Brasília, 14 de agosto de 2015

\section{Banca examinadora}

Presidente:

Lllltatefard

Professora Dra. Daniela Chatelard

Universidade de Brasília

Membro: Koseaue Freitas Micolass

Professora Dra. Roseane Nicolau

Universidade Federal d $\varphi$ Pará

Membro:

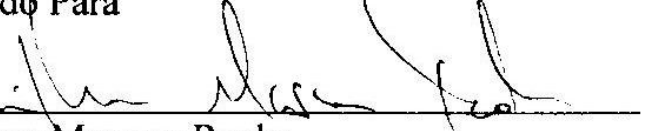

Professor Dr. Gunherme Massara Rocha

Universidade Federal de Minas Gerais

Membro:

Professora Dra. Terezinha de Camargo Viana

Universidade de Brasília

Membro:

Professora Dra. Márcia Cr/stina Maes\$o

Universidade de Brasília $/$

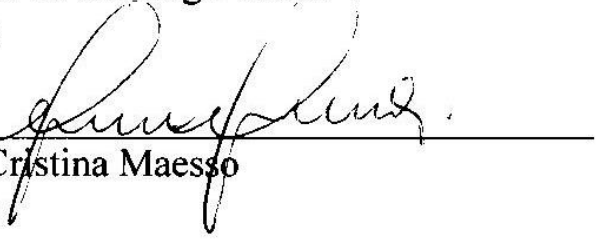

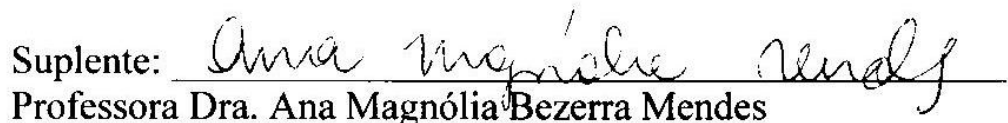

Universidade de Brasília 
Dedico este trabalho a todos aqueles que confiaram seu sofrimento à minha escuta. 
A estrutura da psicanálise, como lembra Lacan, está nodulada à experiência: só se pode entender a estrutura pela experiência.

Daniela Chatelard

A psicanálise, como os esportes e as artes performáticas, precisa, para ser passada adiante, da transmissão corpo a corpo, pessoa a pessoa. A presença física é necessária, porque parte integrante dos fenômenos que são seu objeto ocorre nos corpos dos participantes como sensações, emoções, sentimentos diretamente derivados do contato entre participantes. Muitas coisas precisam ser experimentadas para serem compreendidas; a

Psicanálise é uma delas.

Claudio Rossi 


\section{Agradecimentos}

Ao escrever os Agradecimentos da minha Dissertação de Mestrado, defendida nesta mesma Universidade, comecei por falar da aridez e solidão da escrita para logo em seguida reconhecer que o trajeto da pesquisa é permeado por trocas intensas das mais diversas naturezas. Embora nem sempre relacionadas com a produção acadêmica, tais trocas são vitais para a escrita ter começo, meio e fim, com o menor "surto" possível. Mantenho o ponto: a escrita continua para mim solitária e árida. Até hoje não posso dizer que gosto dela, mas como me meto nisso com alguma frequência, também não posso falar que desgosto. Talvez seja isso o tal "masoquismo primário"...

Dedico, então, estas poucas linhas para lembrar aqueles que, quer saibam, quer não, foram importantes direta e/ou indiretamente para essa produção. Estas parcerias, amorosas nos seus diferentes graus, são o suporte (na ampla acepção do termo) do laço social e da produção. Sem o laço social, não é possível “amar e trabalhar”! Portanto, sem mais rodeios, passo aos agradecimentos!

Primeiramente, agradeço aos Profs. Dra. Roseane, Dr. Guilherme, Dra. Márcia, Dra. Terezinha e Dra. Ana Magnólia por aceitarem o convite para compor a Banca Examinadora. A conclusão da tese é, para mim, um momento de alegria e ansiedade (penso que esse afeto

seja inescapável no contexto de uma defesa). É com grande satisfação que recebi a notícia que o convite fora aceito. Afirmo que é um prazer e um privilégio compartilhar com vocês meus pensamentos, expressos nesta pequena produção, e aproveitar a oportunidade para aprender e debater com vocês sobre um tema tão caro para mim.

Agradeço especialmente aos meus pais por todo amor, carinho, apoio, confiança e incentivo incondicionais. Aos meus irmãos e cunhadas "pela piada no bar e o futebol pra aplaudir" (a despeito do que nosso time anda fazendo...), além da trilha sonora na madrugada e das pizzas do domingo. Não posso deixar passar a oportunidade de lembrar dos momentos em que discutíamos pontos da tese e os comentários de vocês eram: "Não entendi nada, deve estar bom!" e "vai ser uma defesa tipo “prenda-me se for capaz', né?” Agradeço aos meus sogros por todo amor, apoio, carinho e pescarias (muito bom ouvir "acaba logo com isso! Não podemos deixar os peixes esperando!”). Agradeço, muito e sempre, à minha amada esposa 
por toda dedicação, amor, carinho e paciência (esta muito requisitada e nem sempre de modo justo); agradeço por todos os nossos debates divertidos ou tensos sobre psicanálise, direito, evolucionismo e política. Além das coisas do amor, sua influência está desenhada neste trabalho. Enfim, família: nunca conseguiria expressar a contento a importância de vocês!

Agradeço à amiga Luciana pelas valorosas indicações de leitura e calorosos debates no campo da psicanálise. Bem como à querida prima Mari pelas conversas e indicações no campo das Ciências da Natureza. Nossos estudos e conversas foram muito valiosos para este trabalho e, certamente, para além dele. Agradeço muito às amigas Anna Carol, Dri, e Nalice pelos diálogos vivos, inquietantes e produtivos levados, mesmo com toda distância física, sempre com muito carinho. Agradeço especialmente aos grandes amigos Marcão, Mari e Aline por todos os momentos descontraídos e felizes. Meus amigos, de perto e de longe, foi inestimável a ajuda de vocês para segurar as barras mais pesadas que se impuseram neste caminhar.

Agradeço aos colegas, parceiros e colaboradores da Álgebra, pelo incentivo e diálogo em terrenos por vezes árido. Desejo que agora, mais do que nunca, uma vez reunidos sob um novo significante, nossas prosas frutifiquem em bons trabalhos! Agradeço também aos colegas do Laboratório, mestrandos e doutorandos, pelos debates, contribuições, críticas e, claro, nunca esquecerei, pelo carinho e calorosa acolhida quando de meu retorno às atividades de supervisão/orientação.

Agradeço ao colega Mauro pelo suporte nas demandas burocráticas da Universidade, suas dicas foram de grande valia. Assim como ao professor Dr. Prof. Maurício S. Neubern, pelo empenho e sensibilidade ao relatar seu parecer junto ao departamento no momento de maior sensibilidade na minha vida. Sua intervenção possibilitou a conclusão deste trabalho.

Agradeço muito à Nilza, Edna e Maria Helena, de Brasília, e à Kelly, de Belo Horizonte, por todo empenho no destravamento das passagens para os Membros Externos da Banca Examinadora. Sem a ajuda de vocês a defesa não teria acontecido.

Por fim, agradeço enormemente à Professora Dra. Daniela Scheinkman Chatelard por sua orientação precisa, exigente, sempre paciente e acolhedora. Estamos juntos nessa caminhada na psicanálise já há um bom tempo. Passamos vários momentos bons e, 
especialmente nestes últimos anos, barras pesadissímas. Foi, e é, um prazer e um privilégio têla como orientadora e amiga. Com tudo e apesar de tudo, sigamos! 
Oco de pau que diz: Eu sou madeira, beira

Boa, dá vau, triztriz

Risca certeira

Meio a meio o rio ri

Silencioso, sério

Nosso pai não diz, diz:

Risca terceira

Água da palavra

Água calada, pura

Água da palavra

Água de rosa dura

Proa da palavra

Duro silêncio, nosso pai

Margem da palavra

Entre as escuras duas

Margens da palavra

Clareia luz madura

Rosa da palavra

Puro silêncio, nosso pai

Meio a meio o rio ri Por entre as árvores da vida $O$ rio riu, $r i$

Por sob a risca da canoa O rio riu, $r i$ O que ninguém jamais olvida Ouvi, ouvi, ouvi A voz das águas

Asa da palavra Asa parada agora

Casa da palavra Onde o silêncio mora

Brasa da palavra A hora clara, nosso pai

Hora da palavra Quando não se diz nada

Fora da palavra

Quando mais dentro aflora

Tora da palavra

Rio, pau enorme, nosso pai

A terceira Margem do Rio, Caetano Veloso. 


\section{Resumo}

O presente trabalho resgata a história da evolução humana até o ponto que os homens se diferenciam dos primatas. Procura responder ao mistério de estarmos biologicamente prontos e permanecermos culturalmente inertes por um longo período, até o momento conhecido como Grande Salto para Frente (despertar da Cultura), apresentando o conceito de pulsão, próprio da psicanálise, como uma perversão do instinto pela linguagem. Esta perversão é intima à entrada na Cultura.

O conceito de pulsão será desenvolvido na metapsicologia e o destaque será na constituição do aparelho psíquico como aparelho de linguagem. As características da ação da linguagem sobre o ser vivo acarretam num excesso de excitação do aparelho psíquico, estabelecendo uma tensão entre sujeito, sua perda estrutural e o Outro. O inconsciente é abordado como a resultante do tratamento desse excesso (gozo) pelo aparelho psíquico.

As concepções teóricas sobre o inconsciente estruturado como uma linguagem e do tratamento do gozo proporcionam uma subversão do sujeito. Esta operação acarreta uma conta de mal-estar, fonte de sofrimento, inescapável no convívio social. Portanto, a pulsão pode ser entendida como conceito limite entre o simbólico e o real.

Finalmente, serão articulados o desejo e o laço social. Esta relação emerge como uma saída, embora custosa, possível ante o mal-estar inerente ao ser falante. Para tanto, é necessário modular o gozo, na sua dimensão excessiva, nas formas do laço social em arranjos menos fracassado.

Palavras-chave: Cultura. Inconsciente. Linguagem. Gozo. Laço social. 


\begin{abstract}
This paper recalls the history of human evolution to the point that men are different from primates. Seeks to answer to the mystery that we are biologically ready and remain culturally inert for a long period, so far known as the Great Leap Forward (awakening of Culture), introducing the concept of drive, psychoanalysis itself as a perversion of the instinct for language. This perversion is intimate to the entry in Culture.

The concept of drive will be developed in metapsychology and the highlight will be the constitution of the psychic apparatus as a language apparatus. The action of language features on the living carry an excess of excitement of the psychic apparatus, establishing a tension between subject, its structural loss and the Other. The unconscious is approached as the result of the treatment of this excess (jouissance) by the psychic apparatus.

The theoretical conceptions of the unconscious structured like a language and the joy of treatment provide a subversion of the subject. This operation causes a malaise account, source of suffering, inescapable social life. Therefore, the drive can be understood as a concept boundary between the symbolic and the real.

Finally, they will be articulated the desire and the social bond. This relationship emerges as an output, although costly, can at the discomfort inherent to the speaker. Therefore, it is necessary to modulate the enjoyment in its excessive size, in the forms of social ties in less failed arrangements.
\end{abstract}

Key words: Culture. Unconscious. Language. Jouissance. Social lace. 


\section{Sumário}

Introdução: O que virá a seguir

1. A origem da pulsão ou os mitos da origem 39

1.1 Como enterramos os instintos? 42

1.2 A origem do homem: do instinto à pulsão 48

1.3 Um dedo fez a diferença 51

1.4 Ciclo vital 61

2. Nos Trilhos da Pulsão 64

2.1 Células, núcleos e gânglios $\quad 65$

2.2 Entre o psíquico e o somático 69

2.3 Um recalque para haver um circuito 72

3. Feito uma linguagem 76

$3.1 \mathrm{O}$ fim do indivíduo e a constituição do sujeito 76

$\begin{array}{ll}3.2 \text { Casa dos espelhos } & 79\end{array}$

3.3 Se eu estou aqui, como estou lá?

3.4 Where is my mOther? $\quad 85$

3.5 É uma barra! Faz sentido. Tem outro sentido? Não-sentido... 87

3.6 Espelho, Espelho meu, existe alguém mais bela do que eu? $\quad 90$

3.7 Três tempos para um desejo $\quad 94$

3.8 Sexo e morte 96

4. No fim e no começo, o gozo 100

4.1 Do gozo vulgar ao jouissance 101

4.2 Entre o Simbólico e o Real 113

5. O desejo, seu mal-estar: uma saída possível 116

6. Um sopro iluminista 123 


\section{Apresentação: a origem}

Nesta pesquisa, que busca as origens do que chamei de invenção do Humano através do conceito fundamental de pulsão, recorri por vezes a regressões a tempos ancestrais. Portanto, nada mais coerente do que iniciar esta apresentação contando um pouco de minhas origens. Por que fazê-lo? Bom, agora, finda a pesquisa, pude olhar para trás e ver nas minhas próprias pegadas que circulo desde muito ao redor dos temas aqui tratados. Claro, eram elementos dispersos ao longo de minha história pessoal (cuidados em seu tempo com o tempero cabido a cada época) e que agora, juntados, acrescentam um sentido muito particular ao trabalho ora desenvolvido. E é este sentido que gostaria de compartilhar. Num suspiro posso encontrar-me na afirmação que, realmente, não se cria do nada. As próximas linhas não são dedicadas ao trabalho propriamente dito, contam mais do que conceitos teóricos desenvolvidos a partir do esforço da pesquisa. Outrossim, contam uma pequena história sobre o olhar, as origens dos elementos reunidos nesta tese. Elementos que dão pistas do sujeito contido na escrita e de suas metáforas (que aprendemos a chamar de desejo). Se encontramos algo do objeto como causa de desejo na repetição e na insistência das metáforas, o presente trabalho é, a seu modo, mais uma parte da borda que o autor da pesquisa busca fazer na empresa da vida.

Meu interesse pelo mundo natural despertou cedo, ainda mesmo na infância. Colecionava tudo que as bancas de jornal ofereciam sobre "vida selvagem", "predadores", "florestas" e "mares". Fui capturado pela percepção do equilíbrio ecológico e de como as espécies vivas interagiam, entre si e com o meio, numa fantástica dinâmica cuja engrenagem parecia perfeita e sem ruído. Ficava fantasiando hipóteses sobre os dinossauros e chegava até a ficar inquieto com a possibilidade de extinção de espécies contemporâneas pela ação destruidora do homem. Entendia a natureza como uma máquina perfeita, atormentada por uma espécie que parecia recusar-se ao equilíbrio. Devo admitir que pensava: "não faz muito sentido... não é mais fácil fazer o correto?” Anos mais tarde, Guimarães Rosa veio ao meu socorro: “o difícil não é fazer o certo, o difícil é saber o que se quer". Comecei a desconfiar que o desejo, um dos nomes do diabo, nos levava a escolhas por vezes contra-evolutivas. Mal sabia eu que a comichão do desejo, do fantasma dentro da máquina, já me pegara; mas isso é para mais logo. 
Meu ambiente doméstico era rico e muito estimulante. Morava com meus pais e irmãos em uma casa com quintal e jardim. A curiosidade, desenvolvida e estimulada, rapidamente me levou a colecionar (para terror da minha mãe) insetos e pequenos anfíbios. Por óbvio, quando a teoria da evolução de Darwin me foi apresentada, meu universo infantojuvenil se amplificou. A percepção de uma lógica cuja estrutura parecia perfeita me impactou profundamente. Fiquei, pela segunda vez, capturado.

Estudei em um colégio pequeno, que possuía, além das salas de aula, um pequeno laboratório, um dojô, uma quadra de vôlei, uma de futebol de salão e um campo de futebol. Como entrei um ano mais cedo na escola, vivi nessa contingência uma desvantagem física perante a turma de meninos e meninas mais velhos. Usualmente, dividia o tempo do recreio entre a bola e o laboratório. Devo admitir que, até o colégio corrigir a diferença de idade, reprovando-me um ano a título de nivelamento, minha "desvantagem física" fazia o pendor cair mais para o laboratório do que para as quadras na divisão do tempo destinado ao recreio.

Ao transitar pelo laboratório contava com uma vantagem adicional que me permitia um bom laço social: meus pais, médicos, possuíam em casa, dentre outros apetrechos médicos, um microscópio, cuja potência e resolução eram muito melhores do que o da escola, e um negatoscópio. Minha mãe, com muita frequência e paciência, mostrava imagens de tecidos e células, e chamava minha atenção para pontos muito para além do "bê-á-bá" da escola. Portanto, tinha muito "papo" para contar para os colegas e algumas perguntas perspicazes na manga para os professores. Nascia um híbrido de curiosidade e brincadeira e, ainda de quebra, superava um inconveniente do ficar "na de próxima" na hora dos jogos.

Feita a referida realocação para uma turma com idade mais adequada, comecei a ter uma resposta mais positiva às coisas pertencentes ao universo das atividades físicas e uma interação social mais suave. Alcancei algum reconhecimento nas performances esportivas e por elas ganhei gosto. Entrei em campo e no dojô, e até hoje não saí.

No segundo grau, passei a estudar em um colégio maior, pois havia o "temido" vestibular no horizonte... Com essa idade, as pequenas coleções já haviam ficado para trás, embora o fascínio pelo mundo natural não. Contudo, outros interesses começaram a concorrer com os estudos e os esportes. Devo admitir que os estudos formais, muito conteudistas em minha opinião, ficaram no limiar da negligência. Minha cabeça virava para tudo, menos para 
os estudos. Neste período intensificaram-se as excursões pela literatura, desenho, música e cinema (paixões que aprendi com meu pai). Eis que, dentro da grade curricular convencional, havia uma matéria chamada História Social das Artes. Meu radar voltou-se para as humanidades. A disciplina estimulava enormemente a literatura, ciências sociais e filosofia. Aquela referida lógica bem azeitada do mundo natural parecia liquefazer-se em enigmas, com furos, pois as humanidades colocaram um fantasma dentro da máquina. O objetivo da matéria pouco ou nada tinha ver com conteúdo. O que interessava era "questionar", "questionar tudo". As aulas consistiam em acalorados debates sobre os livros e filmes. O único fio condutor eram as sugestões dos temas dadas na aula anterior. Finalmente, num desses acasos da vida, alguns meses antes do vestibular, caiu em minhas mãos, por conta dessa disciplina, um exemplar da Interpretação dos Sonhos de Sigmund Freud. Fui, pela terceira vez, capturado. E o livro acabara de me dar a direção do que gostaria de ter por profissão. O curso de psicologia pareceu-me então o caminho mais rápido para este novo objetivo. Olhando para trás, penso: “que diabos um menino de 15 anos estava fazendo com a Interpretação dos sonhos?”. Não me recordo sobre o que entendi da obra, mas posso falar que fiquei impressionado. As águas se dividiram.

Em razão de algumas contingências, ingressei na Universidade Federal de Minas Gerais (UFMG), e para lá fui “de mala e cuia". Mudei para outra cidade, sem referências familiares e ainda menor de idade. Vivia praticamente dentro do Campus. Como era de se esperar, o curso de psicologia diferia em muito do que eu supunha que era. Na verdade, não chegou a ser uma decepção, pois uma vez vencido o ciclo básico pude direcionar o curso para a psicanálise. Essa sim foi uma surpresa! Quanto mais conhecia, mais renovava meu interesse por ela, na mesma proporção que as certezas derivadas do narcisismo juvenil iam se desfazendo. Não sabia bem onde estava me metendo, mas sabia que queria escutar as pessoas. Montei, no que foi possível, minha grade para a psicologia clínica, com ênfase na psicanálise e na psicopatologia. Claro, não foi um caminho pacífico, nem posso dizer se hoje o é...

Quando da conclusão do curso, na UFMG, não era exigido um TCC. Contudo, por iniciativa do Prof. Dr. Guilherme Massara, organizava-se o Primeiro Ciclo de Jornadas Clínicas do CAEP. Apresentei à época uma monografia intitulada Trilhamentos da Pulsão. Este trabalho representou para mim a conclusão do curso de graduação. 
Graduado, abri consultório, e pude contar com a inestimável escuta do Prof. Dr. Guilherme como supervisor. Concomitantemente, fui contratado para atuar como psicólogo clínico junto ao Centro Mineiro de Toxicomania (CMT), onde fizera um dos estágios da graduação. O CMT é um CAPSad, referência do Estado de Minas Gerais, dispositivo da Fundação Hospitalar de Minas Gerais (FHEMIG), para atenção a usuários de álcool e outras drogas. À época, possuía a característica de ser um serviço público cuja direção do tratamento era toda de orientação psicanalítica. Além da pesada rotina de atendimentos, tínhamos reunião clínica semanal para discussão dos casos e jornada de trabalhos anual. A severidade dos casos, a obrigação de apresentá-los e discuti-los com a equipe, o sistemático diálogo com outros saberes como a clínica médica e a psiquiatria, constituíram inestimável valor na minha formação e escuta. Muito do psicanalista que sou hoje, foi talhado lá. Permaneci no CMT três anos, até retornar a Brasília.

Durante esses anos, após formatura, participei das Formações Clínicas do Campo Lacaniano-BH, onde aprofundei e estabeleci fortemente minha transferência com o ensino de Jacques Lacan. Durante todo período em que estive em $\mathrm{BH}$, mantive-me atendendo, escutando pessoas, no consultório. E, ao olhar minha trajetória até o presente momento, percebo inequivocamente que todos os trabalhos que fiz orbitam em torno do consultório. Posso dizer com tranquilidade que minha escuta foi forjada na atividade clínica.

Chegando a Brasília, procurei a Prof. Dra. Daniela Chatelard, inicialmente pela referência ao Campo Lacaniano, e começamos nossas conversações. Posteriormente, torneime seu orientando do Curso de Mestrado nesta Universidade com o trabalho intitulado: Ensaio psicanalítico sobre as toxicomanias, defendido em 2006. Nossa prosa se estende até os dias de hoje (e, ao que tudo indica, deve continuar!).

Paralelamente, fruto das conversações com a Prof. Dra. Daniela, organizamos com alguns colegas analistas um pequeno grupo dedicado à transmissão da psicanálise. Começamos com Seminários semanais, em alguns períodos quinzenais, e mantemos esta atividade até os dias de hoje. Como toda organização de psicanalistas, mudamos de forma, nomeação, membros, mas, com muita satisfação, contamos até hoje com os membros fundadores. Alguns outros valores somaram-se ao núcleo inicial durante esse percurso. Exatamente nesse contexto, tive a oportunidade de começar os diálogos com a Prof. Dra. Márcia Maesso, cujas valiosas contribuições enriqueceram nossos debates lá e cá (neste 
trabalho). Inclusive, a metáfora do Nome-do-Pai da cultura colocando limite na Mãe-natureza é devida a ela, quando da qualificação da presente pesquisa.

Retomemos. Ao chegar nesta cidade, abri meu consultório e comecei a atuar junto à Coordenação de Saúde Mental do Ministério da Saúde do Brasil (MS), na área técnica de álcool e outras drogas (ad), paralelamente aos fatos acima lembrados. Aqui tive a primeira aproximação íntima e real com a gestão de políticas públicas. É um tanto da vida como ela é. Descobri que não havia espaço para teorias abstratas ou romantismos ideológicos. Os desafios eram gigantescos, e os meandros políticos e institucionais não permitiam grande tempo para amadurecimento. As decepções foram brutais. Foi o período no qual tive a oportunidade de vivenciar, da "janela lateral", mais profundamente as organizações, suas virtudes e vícios, além de participar da construção/execução de políticas públicas cuja afetação atingia em cheio a ponta: os usuários e trabalhadores dos serviços de saúde mental. Pude ver com proximidade bons e maus projetos e debates; vi a força do poder que "ergue e destrói coisas belas", vi o pendor entre o técnico e o político revelar nos agentes das ações o que há de melhor das intenções e de pior das ações. Localizo aqui, precisamente, a consolidação do meu interesse pela relação das instituições e organizações do campo social e sua interferência (de)formadora na subjetividade das pessoas na sua particularidade. Acredito que a implicação política (não falo de política-partidária) é um imperativo ético não só do cidadão, mas do sujeito como quer a psicanálise. Lembro Goldenberg (2006) quando afirma que a "psicanálise se ocupa precisamente dessa relação complexa entre individual e coletivo que constitui o problema central de toda e qualquer ação política”. Penso que as pessoas são o que são, dadas razões por vezes só reveladas numa análise. Contudo, a relação íntima do sujeito com o campo social, através de suas instituições, modifica o jogo de forças desta balança. O pacto edípico ensinado pela psicanálise mostra que, para estabilizar as subjetividades, justamente pelo valor traumático da perda na natureza, somos todos contratualistas. Em razão disso, observar-se-á ao cabo deste trabalho uma inclinação para o campo do direito, pois a psicanálise nos ensina a todos que este bicho que fala e carrega armas, organiza-se tanto psíquica quanto subjetivamente por meio de seus contratos, suas leis.

Ao sair do MS, após dois anos, retornei integralmente à atividade clínica. Somei ao consultório algumas horas dedicadas novamente à saúde mental, agora no atendimento clínico em hospital-dia e internação dentro de uma instituição psiquiátrica privada. Retornei então ao nicho que me sentia (e me sinto) mais à vontade: o consultório, a clínica. 
Este período também cumpriu seu curso quando desejei regressar ao Programa de Pós-graduação da Universidade de Brasília (UnB). Minhas atividades foram então divididas entre a Universidade e o consultório. Tudo parecia caminhar bem, até que uma contingência devastadora surgiu na esfera da minha vida particular, como uma "roda-viva", daquelas que "leva a gente pra lá". Realizei, por todo o trauma imposto, a total falta de sentido e o deserto da experiência. É o corte "lento e profundo" que faz a gente pensar que "viver não é tão bom quanto na semana passada". Voltei ao ponto de origem: não existe justiça ou razão para a presa quando o predador cerra os dentes. Não existe justiça ou razão para o predador que sucumbe à fome quando a presa escapa. A natureza é. Conheci o que aprendi a chamar de atravessamento real. O Real é. Por efeito desta pancada, tive que me afastar e até mesmo pensei em parar... Francamente, não posso dizer que passou, posso falar que sigo. Sigo nesta tese, sigo no consultório e sigo na vida. Sigo cantando: I'm half a man I used to be. E seguindo adiante, com e apesar do real, talvez por força dele, apresento-lhes este trabalho como mais um pedaço da borda. 


\section{Introdução: o que virá a seguir}

A pesquisa é intitulada "Inconsciente: As Origens da Pulsão e a Invenção do Humano". Algumas perguntas nos nortearam ao longo dessa jornada. Vamos à elas: o que poderia justificar o fato de ancestralmente, embora já sermos biologicamente modernos, termos ficados tanto tempo inertes culturalmente e de repente avançarmos vertiginosamente? Seria o inconsciente e o campo pulsional os responsáveis por enterrar os instintos e lançarnos para a Humanidade? Quais os elementos precursores desta uma nova forma de ser (sujeito), já que não éramos no despertar cultural um novo ser (espécie)? Como o abandono da Natureza e a entrada na linguagem constituem o sujeito? Como se dá a lida com o excesso excitação que a entrada na Linguagem provoca? Como umas sociedades oferecem desenhos melhores do que outras para suportar o peso das renúncias pulsionais? O estudo do Inconsciente e das Origens da Pulsão nos dá a oportunidade de pesquisar os pontos fundamentais da teoria metapsicológica e avançar um pouco nos mistérios do humano.

Os instintos estão fortemente ligados à ciclacidade, tendo sua manifestação acionada por estímulos intermitentes. Até aqui, todas as espécies estão regidas pelas mesmas regras, sofrendo pressões de mesma natureza. Sobrevivência e reprodução balizam todos os viventes. A evolução da nossa espécie criou um evento bastante peculiar, e até então original, dentre todas as espécies existentes (DAWKINS, 2009, p. 55-57), o chamado Grande Salto Para Frente (DIAMOND, 2012). Segundo achados arqueológicos, nossa espécie já havia atingido o desenvolvimento anatômico e cerebral moderno, mas permaneceu com hábitos primitivos e culturalmente inerte por muito tempo. Estes hábitos pouco se distinguiam dos de outras linhagens da espécie Homo, contemporâneos a nós, ou dos grandes símios. Ou seja, embora produzíssemos sons específicos (palavras) com intenção e eficiência de comunicação, e manuseássemos alguma tecnologia, não éramos mais espertos que os "outros macacos", nem fazíamos nada que eles não fizessem. Logo, não foi só o uso intencional da linguagem e de instrumentos que fez a diferença.

Uma das teorias em voga propõe que o Salto pode ter se dado em razão de uma nova habilidade linguística: o uso de palavras com função apenas gramatical (DIAMOND, 2010, p. 185), orações condicionais e o uso de palavras referenciais (sem a necessidade da presença ou 
existência do referente), possibilitando o surgimento do símbolo (DAWKINS, 2009, p. 57). Embora seja incontestável a base genética, a mudança que abriu espaço para a humanidade foi impelida pela cultura nascente ao descortinar um universo simbólico (DAWKINS, 2009, p. 53). A linguagem, com sua nova propriedade além-representação, modificou a carne do ser vivo, trazendo possibilidades superiores à atribuição de sentido e intenção. Portanto, defendemos que o impacto da linguagem no ser vivo modificou-o. A decadência dos instintos, dada a desnaturalização que a linguagem provoca, demandou não um novo cérebro, mas muna nova função psíquica. A linguagem passa a ser um ente autônomo e anterior ao falante que é constituído por ela. Eis nossa revolução!

Uma nova habilidade linguística demanda um novo aparelho de processamento. Certamente, o abandono do referente possibilita que os arranjos entre as unidades de representação linguística articulem-se entre si, criando uma infinidade de arranjos. Mas, o que está em jogo não é propriamente o referente, e sim a capacidade de o aparelho psíquico ser desenhado para trabalhar com representações. Portanto, ao conceber um aparelho que incompatibiliza percepção e memória (FREUD, 1950 [1895]), algo é logicamente perdido de maneira irrecuperável, e a subjetividade passa a ser organizada em um novo topos.

O novo aparelho psíquico abriu a possibilidade do duplo-sentido, embaraçando-o com o não sentido. O referente está excluído da unidade linguística, como quer Freud (1977) nas Afasias... e Saussure (1996) no Curso de Linguística Geral, podemos, então, falar uma coisa e alcançar outra pela própria articulação das representações de palavra e coisa ou do significante e significado. Nisso algo sempre há de escapar, pois a representação nunca mais alcançará o representado. Está aberto um campo no qual a representação do mundo pode sofrer rearranjos por estruturas somente linguísticas.

Portanto, a partir do aparelho psíquico desenhado pela pesquisa psicanalítica, propomos que não foi o abandono do referente que criou uma nova ordem, cujos efeitos seriam imprevistos. Entramos no reino do psíquico, no qual uma função específica criaria um aparelho de linguagem. Diamond (2009, p. 49) é categórico em afirmar que nossa ascensão à humanidade não foi diretamente proporcional a nossa mudança genética, pois como falamos, embora biologicamente prontos, permanecemos culturalmente inertes por um bom tempo. Propomos que a linguagem operou a mudança no ser vivo. A imagem da banda de Mobius pode representar esta relação contínua de intri-extricidade da carne com a linguagem. 
Mas como enterramos os instintos? Diamond (2010) destaca três grandes mudanças que separaram nossos ancestrais dos grandes símios e os aproximaram do que entendemos por homens modernos. A primeira mudança foi a adoção da postura ereta. A liberdade dos membros anteriores possibilitou uma profunda modificação nos hábitos, destacadamente a confecção de ferramentas, que radicalizaria o potencial do homem para modificar o meio ambiente. A segunda mudança seria a divisão de nossa linhagem em duas espécies distintas. Duas espécies vivendo na mesma área devem realizar papeis ecológicos distintos e, normalmente, não reproduzem entre si. A terceira foi o uso regular de ferramentas e a transmissão do conhecimento de seu uso e confecção.

Estudos arqueológicos sobre as fezes fósseis dos homens primitivos revelam muito de seus hábitos alimentares, possibilitando a inferência de alguns de seus hábitos sociais. Os homens primitivos eram essencialmente caçadores-coletores, sendo a alimentação basicamente constituída por vegetais, pobres em nutrientes, com pouca participação de alimentos ricos em proteína. Ou seja, muito tempo destinado à alimentação e, vez por outra, aos vegetais somava-se algum pequeno animal ou ovos. A organização social dava-se em pequenos grupos familiares nômades. Contudo, o homem primitivo já possuía cérebro maior, andava de pé e confeccionava ferramentas rudimentares. Ora, o cérebro grande, um aparelho fonador e a postura ereta eram a base da capacidade de articulação de uma linguagem falada complexa, mas era preciso algo mais.

Com a modificação anatômica necessária para abrigar um cérebro maior, a prole diminuiu e o filhote humano teve que nascer antes do pleno desenvolvimento de seu sistema nervoso. Com estas características, ocorreu uma mudança no ciclo vital e no comportamento. Necessariamente, a infância ficou prolongada, criando a necessidade de organização social para caça, coleta, proteção e procriação (MORRIS, 2004). Textualmente, Diamond (2010, p. 67) afirma que a fala teve uma importância crucial nas relações entre homem, mulher e sua prole. A característica de transmissão e desenvolvimento cumulativo destacou o desenvolvimento cultural do desenvolvimento genético. O Grande Salto Para Frente lançou o homem para a humanidade.

A nova organização social, sustentada na anatomia moderna, remodelou o sexo e criou a sexualidade. Os hábitos sociais e o ciclo de vida modificaram as formas de cuidar da prole, de obter alimentos e de utilizar ferramentas (DIAMOND, 2010, p. 78). A ocultação do 
período fértil das fêmeas humanas, assim como a menopausa, são mostras que a função biológica da copulação não é a reprodução. O abandono do cio, do instinto, lança a pulsão para suas características perversas e polimorfas (FREUD, 1905).

A organização da sociedade humana e o estreitamento dos laços são fortemente dependentes do sexo, que ganha características mais ou menos monogâmicas, com sua busca privada e constante. A seleção dos parceiros sexuais, célula nuclear da organização social humana, orientou-se para outros aspectos além do vigor e beleza físicos, indicativos sensíveis de saúde e fertilidade (MILLER, 2004). A seleção sexual buscou os cérebros. Os produtos da mente, como linguagem, sagacidade, generosidade, confecção de produtos, capacidade de intervir no meio, e toda uma infinidade de possibilidades tornaram-se, por assim dizer, sexualizados. Ora, algum nível de regramento, repressão, teria de se impor para arrastar o sexo para a sexualidade e manter o homem cada vez mais nos meios de linguagem. Os estudos de Miller (2000) no original A mente seletiva - como a escolha sexual influenciou a natureza humana, propõe que os produtos da mente humana são os poderosos atratores e determinantes da escolha de parceiros.

Devido ao desenvolvimento evolutivo da nossa espécie, alcançamos um cérebro e um aparelho fonador, cujo desenho é genético, capaz de influenciar/modificar o meio. Mais do que a fala, ou a habilidade de comunicação, a linguagem cria um novo meio, produz objetos onde nada havia e torna o homem fortemente dependente destes objetos. Munidos dessas novas características, os homens colocam uma verdadeira revolução em curso. As funções olfativas, extremamente importantes para os mamíferos, sofrem um importante decréscimo nas suas potências, uma atrofia mesmo.

A atrofia da função olfativa acentua a perda do determinismo biológico. Com isso, o olfato dependente do ciclo periódico perde importância para a visão, função de estimulação constante, para o campo sexual (JORGE, 2005). Esta supressão leva o homem à sexualidade, desvinculando-a do cio e da procriação. $O$ olhar passa a ter uma função como objeto da pulsão. Esta atrofia do olfato e a primazia do escópico inauguram o campo pulsional e o separa do sexual. Características que unem a sexualidade e o infantilismo (JORGE, 2005) passam a constituir no olhar a passagem do instinto à pulsão. 
Como destaca Oliveira (1999, p.19), Freud aponta para a ruptura da relação palavraobjeto. Consequentemente, no processo de significação da palavra, o referente fica de fato excluído, pois não faz parte dos termos da operação, e a ênfase recai na relação do significante com o significado. Modificações na anatomia muscular do aparelho fonador, o que não deixa registro fóssil, podem ter levado ao controle e à variação de sons. Com o controle fino do som, a capacidade criativa foi desenvolvida lentamente, podemos pensar que foi "a palavra falada que nos fez livres" (DIAMOND, 2010, p.67).

A comunicação e a mudança alimentar interferiram nos hábitos e, de forma mais aguda, no ciclo de vida. Abandonado o nomadismo advindo com o caminhar terrestre, surgia o territorialismo. Como Morris (2004, p. 26) observou, aqui está o limite entre a biologia e a cultura. Nesta interseção está o homem e o nascedouro do inconsciente.

O progresso e sucesso da espécie não dependeriam mais da genética. A cultura e seu meio de propagação, a linguagem, são os novos determinantes. A responsabilidade com a prole, com os parceiros sexuais e de caça, estendeu-se para intervenções no meio: abrigos, conforto, proteção, fogo, utensílios, e nunca mais paramos. Nasciam as famílias, com laços fortes e organizados por clãs. A necessidade imposta pela pressão da natureza uniu o grupo, criou responsabilidades entre os membros e com o território. Mas, o grito primitivo de ascender no bando, tomar para si as fêmeas e expulsar os machos concorrentes deveria ser sufocado por uma ação eficiente. O uso de armas impõe que o instinto assassino seja barrado, pois uma desavença poderia ser fatal para o indivíduo e, consequentemente, para o grupo. Os inibidores externos possuem eficiência limitada. Uma operação mais complexa e efetiva deveria acontecer para arrancar o homem da natureza e inseri-lo na ordem da cultura. Eis a base para uma atividade psíquica: o recalque e a Lei.

A atrofia do olfato está na base do recalque orgânico. Paralelamente, a ocultação do período fértil das fêmeas deixava-as constantemente disponíveis para o sexo, introduzindo a vontade e o desejo como determinantes no lugar do cio. $\mathrm{O}$ abandono da ciclacidade (olfatocio-instinto) para a constância (visão-desejo-pulsão) do estímulo sexual demandaria, necessariamente, um inibidor eficiente e universal da sexualidade (recalque).

Eis aqui os rastros desta confusão. As características sexuais são produto da evolução de antepassados arbóreos e comedores de frutas. Sofreram modificações a partir do 
incremento dos hábitos carnívoros, dadas às mudanças impostas pela vida de caçador de campo aberto. A interação destes dois fatores levou ao desenvolvimento de uma estrutura social complexa e organizada para garantir o sucesso da sobrevivência da espécie. Morris destaca que a primeira transformação foi lenta e teve sucesso relativo. Já a segunda foi rápida, desarmônica, e ditada mais pelas proibições impostas e pela inteligência do que pela mudança genética e instintiva/comportamental. $\mathrm{O}$ autor chega mesmo a afirmar que "o comportamento sexual moderno foi menos influenciado pelo progresso da civilização do que esta foi influenciada pelo comportamento sexual" (MORRIS, 2004, p.55-6).

Como nossos corpos foram desenhados para emitir estímulo sexual o tempo todo, por consequência nossa mente ficou fortemente seletiva nesta direção (MILLER, 2000). O desenvolvimento de próteses ganhou o peso de fenótipos estendidos. Sendo partes destacáveis de nós, do nosso corpo (DAWKINS, 1999), levaria com naturalidade à erotização destes objetos culturais (aqui incluímos também os hábitos e habilidades) como atratores e estímulos eróticos. É o passo dado no sentido de uma seleção sexual (DARWIN, 2004). Desenvolvemos então uma intervenção cultural nos corpos para mostrar e velar tais estímulos.

Os primatas desenvolveram uma habilidade social interessante. É um artifício de situação chamado de remotivação. Consiste em mandar sinais sexuais, sem a efetiva disponibilidade para a cópula, para diminuir ou neutralizar comportamentos agressivos ou dominantes de outro membro do bando. Nestes surgem modificações da agressividade a partir da excitação sexual, mesmo que discreta.

Embora perigosa, a estratégia é boa! Emitimos sinais sexuais para remotivar comportamentos. Claro que isso gera ambiguidade e demanda trabalho psíquico. Sem muito esforço, observamos como esta estratégia foi determinante para o prolongamento da infância, a referida neotenia. Erotizar o bebê, incrementar cuidados, erotizar os cuidadores, foram mecanismos determinantes na construção do psiquismo e das sociedades. Então, mais do que desruptiva, a utilização de comportamentos sexuais em situações não sexuais é uma poderosa força de harmonização e organização do grupo, mas acarreta em custo para o indivíduo.

Para alcançarmos o referido custo, nos dediquemos à pulsão em Freud. Começaremos pela exploração das pesquisas neurológicas do médico Freud, para depois demonstrarmos o circuito pulsional do Freud psicanalista. Esta visita justifica-se por ser a 
neurologia o berço intelectual de Freud, estando ali presentes os embriões dos principais conceitos psicanalíticos. Por exemplo, o modelo das afasias, mesmo sendo consagrado como uma teoria freudiana pré-psicanalítica, possibilitou desenvolver e distinguir da neuropsicologia médica uma metapsicologia psicanalítica.

Nestes textos pré-analíticos já estão presentes elementos suficientes para falarmos de um modelo psíquico funcionando como um aparelho de linguagem (OLIVEIRA, 1999). Está em discussão o efeito que a linguagem imprime na carne do vivente, justamente pelo fato deste vivo ser falante, dotado de um aparelho de linguagem desenhado e modificado por esta mesma linguagem.

Freud pesquisou de testículos de enguias a feixes cerebrais. Pôde perceber em estruturas primitivas organizadas indefinições quanto ao sexo. Nesta época, já produzira trabalhos sobre a bissexualidade de espécies primitivas, localizando na base anatômica seus argumentos. O ponto mais alto da pesquisa neurológica de Freud veio nas descrições e inferências extraídas da neuroanatomia funcional. Neste ponto, Freud começa a distanciar-se de seu professor Theodor Meyner. Para este, o corpo seria projetado no córtex, aquele propunha que o corpo se representava no córtex. Objetivamente, para Freud "a relação entre corpo e córtex não é topológica, porém funcional” (GAMWELL \& SOLMS, 2008, p. 105). Vemos aqui uma transição para o modelo metapsicológico, apartado das teorias neurológicas localizacionisatas prevalentes à época.

A exploração das estruturas físicas rendeu a possibilidade de generalizar o princípio. Ora, se estruturas primitivas podem existir em organismos modernos, o mesmo pode ser aplicado a funções. O primitivo e o infantil ganham privilégio na construção do modelo freudiano da mente. Posteriormente, a lógica do modelo de aparelho ou máquina seria utilizada para alcançar as afasias.

Freud (1977) toma a palavra como a unidade funcional da linguagem, e a descreve como uma complexa montagem de representações. Segundo Freud, origem auditiva da linguagem conferia a ela a característica de concretude, justamente por ser perceptual. Ora, isso possibilita dizer que as neuroses são distúrbios funcionais do sistema nervoso. Não o sistema neuroanatômico, mas o sistema de linguagem, cuja realidade psíquica é concreta. As estruturas neurológicas já não são o objeto de Freud. Seus desenhos e diagramas, embora 
busquem nomeações de funções neurológicas, são esquemas de representação cada vez mais abstratos de um aparelho psíquico constituído, modificado e operado pela linguagem. Esta assume características concretas e marca a carne do vivente justamente por ele ser falante.

Freud (1905) afirma que a pulsão é o conceito limite entre o psíquico e o somático. Assim, a pulsão teria sua fonte no corpo, mais precisamente nos órgãos do corpo e não no corpo organizado do organismo; e seria um estímulo para o psíquico, não um estímulo psíquico. Deste modo não é possível ou aceitável tomarmos os representantes da pulsão (triebrepräsentanz), ou ainda, os representantes psíquicos (psychische repräsentanz) pela própria pulsão (trieb). A pulsão está fora do aparelho psíquico, seus representantes estão dentro.

Como a pulsão é força que vem de fora do aparelho psíquico, estimula e compele à ação, vamos ao Projeto... (FREUD, 1950 [1895]) para resolver o problema da distinção do que é estímulo interno e externo. O sistema de neurônios $\psi$ é estimulado a partir de duas fontes. Uma exógena, que chega através do sistema dos neurônios $\varphi$, e uma endógena que afeta diretamente ao núcleo do sistema $\psi$. Estes estímulos produzem Qs, quantidades de energia, que excitam os neurônios. É da natureza do neurônio oferecer resistência à excitação, demandando quantidade de energia para romper o limiar de repouso e passar o estímulo para frente. Ao separar as fontes de excitação em endógenas e exógenas, Freud chega a conclusão que as fontes afetam diferentemente o sistema $\psi$. As excitações provenientes do mundo externo não atingem diretamente o sistema $\psi$, perdem força ao transitar pelo sistema $\varphi$, que contém os órgãos dos sentidos. Os estímulos endógenos não contam com um sistema de filtro entre os órgãos e o sistema $\psi$, deixando este desprotegido contra a excitação causada pelas Qs oriundas do interior do corpo. Justamente por isso, é possível ver nessa Q de afetação direta a matriz pulsional no aparelho psíquico. Estes estímulos provenientes do corpo chegam ao psíquico para, a partir daí, serem trabalhados. Entenda-se bem, trabalho psíquico é diminuir a excitação do aparelho psíquico.

O circuito pulsional corre sempre do genérico para o específico. Inicia-se a partir de uma fonte pulsional, gera estímulo pulsional, até a estase/acúmulo atingir níveis necessários de pressão. Neste ponto temos uma dupla destinação possível antes de gerar descarga e satisfação: arco reflexo, reações somáticas ou ideia/representação mais afetos (HANNS, 1999). 
A noção de recalque primário é estruturante do sujeito, sendo a repressão um mecanismo de defesa secundário. O conceito de recalque primário, original, eleva-o ao nível de elemento constitutivo do inconsciente (JORGE, 2008, p. 23). A ocorrência do recalque e da repressão já denuncia a operação em dois níveis de sistema psíquico. Na passagem de um elemento qualquer de um sistema para o outro, esse elemento sofre transformações ao modo da refração da luz.

No período em que dedicava seu ensino ao retorno a Freud, Lacan (1998, p.96) adverte seus interlocutores que a função do eu não é a do eu da consciência, sendo-lhe, em alguma medida, oposta. Este descentramento da consciência é fundamental para todo o desenvolvimento da psicanálise, do inconsciente como lugar, e de nossa argumentação.

Utilizando-se da psicologia comparada, Lacan articula o fenômeno de o filhote humano reconhecer-se na imagem refletida no espelho como o logro da unificação do $e u$ adquirida antecipadamente. Os processos de formação do $e u$, demonstrados pela experiência psicanalítica, levam a uma reflexão diversa do eu-indivíduo, apontando propriamente para um eu fragmentado, desconhecido e dessemelhante a si próprio (LACAN, 1998[1949]).

No falante o processo decorre da alienação na própria imagem, para integrar minimamente o corpo despedaçado pelas excitações, falamos de pulsão, não de instinto. Lembremos com Freud que o ego é formado a partir da diferenciação dos estímulos endógenos e exógenos. A formação do ego é uma necessidade que surge para atender ao princípio de realidade, diferenciando-o do princípio do prazer. Surge impondo-se como barreira, filtro para os referidos estímulos, originado das marcas que estes estímulos deixam no aparelho psíquico que ora começa a constituir-se (FREUD, 1950 [1895]).

A formação do $e u$ está ocorrendo em dois campos, um real e outro virtual. O (moi) constitui-se sobre a imagem do próprio corpo, imagem esta inexistente enquanto ser, posto que é reflexa, inexistindo sem o espelho. O efeito psíquico desta imagem é vital. O júbilo da imagem está justamente na constituição alienante do Um, pois na tentativa de capturá-la, é-se capturado pela imagem. Esta é a matriz simbólica do eu que possibilitará toda a subjetividade. O eu é formado por identificação; identificação cuja base é antecipada por sua imagem completa. Quem ascende é um $e u$ impostor, pois a ilusão necessária da completude encobre a fragmentação inerente ao ser da fala. 
Assim, o processo conhecido como Estádio do Espelho possui estatuto maior do que um "momento do desenvolvimento humano", como diz Lacan (1986, p. 91). A superação do despedaçamento do corpo, da fragmentação das pulsões, não seria possível sem o narcisismo. A imagem do corpo no espelho opera como gatilho da libido que circula do corpo à imagem, da imagem ao eu e ao mundo, produzindo seus efeitos. O registro assim estabelecido é conhecido como imaginário. A cobertura que a libido pode então fazer sobre os objetos externos e sobre o próprio corpo dá a estes o estatuto de objetos fálicos, que, na sua vertente imaginária, são próteses para a falta. Lembremos que em tempos primitivos, a construção e incorporação das próteses foi um importante precursor para a saída da natureza e para a abertura da humanidade.

Contudo, não é sem dificuldades que ocorre essa acomodação do imaginário no homem (LACAN, 1986, p. 164). O horror da experiência de castração é ligado àquilo que se vê, conferindo o desvio da imagem a possibilidade de eludir a falta (CHATELARD, 1995, p. 83). O despedaçamento é vivido de modo intenso, demandando ao outro uma ação específica. Esta ação não vem só, traz no ato do outro o acesso ao Outro. Perde-se aí um objeto jamais recuperado (LACAN, 1988). Lacan chega mesmo a afirmar que "nada de fecundo ocorre para o homem a não ser por intermédio de uma perda do objeto" (LACAN, 1985, p. 174).

Com Lacan (1985, p. 37) vimos que o eu não é posto desde as origens. É uma função psíquica adquirida pela ação da linguagem no corpo, pois não se trata de uma ontologia, mas dos efeitos da linguagem. Assim, esta articulação parece oferecer sustentação para a tese de que o inconsciente é efeito da linguagem, estruturado como uma linguagem, e que este efeito proporcionou o Salto, ou seja, o rompimento com a Mãe-natureza e o florescimento da civilização.

Nestes termos, temos no Estádio do Espelho a operação de dois registros, o imaginário e o simbólico, contornando o despedaçamento que mais tarde será nomeado por Lacan como real. Este, sim, já está nas origens, mesmo sob o signo do instinto de morte, perda indelével assinalada já na referência ao Curso... de Saussure (a linguagem é anterior ao objeto, deixando o real inacessível). É ao real que o aparelho psíquico desenvolve-se em resposta para conter o horror do despedaçamento. A construção de uma unidade corporal ancorada na imagem é testemunho do trabalho psíquico envolvido nesta empreitada. $\mathrm{O}$ declínio dos instintos e a assunção das pulsões, com seus representantes pulsionais compondo 
a gramática inconsciente, lançou a realidade ao real, enterrando-a na marca de algo sempre perdido e inacessível.

A com/fusão decorre do fato de o desejo ser reconhecido pela ação mediadora da imagem própria e do corpo do outro, sendo por este corpo que se reconhece o desejo. É neste desenvolvimento que o desejo do sujeito funda-se no campo do Outro, sobre as bases do corpo do outro. O desamparo original possibilita que o desejo se aloje no outro, este detentor de objetos que podem ser investidos de forma fálica.

Lacan relê o inconsciente freudiano fazendo-o um Outro. É o sujeito descentrado em relação ao indivíduo. Do outro ao Outro, Lacan colocará o inconsciente estruturado como uma linguagem, sendo seu sujeito efeito do significante. Este ponto é essencial para a articulação do sujeito, pois assim como o $e u$, o sujeito não é dado de saída. É ainda mais evanescente, posto que o sujeito é constituído a partir do momento da fala, não antes, no desenrolar do plano simbólico.

É necessário introduzir um corte — função simbólica por excelência- para o sujeito presentificar-se e dele extrair consequências. Temos então a notação de sujeito do inconsciente por $(\$)$ para denotar-lhe a marca do recalque. É justamente pelo fato do eu resistir, de haver dessemelhança entre o (je) e o (moi), que os efeitos da comunicação no nível do inconsciente são apreensíveis. Aí mesmo, no equívoco, no duplo-sentido, ocorre a tensão do eixo imaginário, lançando-o para mais além da significação. Este é o corte que o muro da linguagem faz operar por meio do simbólico, possibilidade do sentido deslizar pelos significantes em busca da significação, sem, contudo, estabelecer relação de identidade entre significante e significado. Não é por menos que Lacan retoma as leis da via Regis, descritas por Freud (1900) como condensação e deslocamento, renomeando-as nas figuras da metáfora e da metonímia.

Lacan (1985, p. 221) confere ao nível em que o símbolo surge a parte essencial da experiência humana, a ocorrência do sujeito enquanto sujeito da fala, do inconsciente. Essa barra, desvelada pela experiência psicanalítica, revela uma profunda divisão do $e u$, sede do desconhecimento e da descontinuidade inerente ao eu. Nesta álgebra há um termo (traço de memória) que se preserva e há um termo jamais encontrado, cuja ausência impõe um eterno retorno ao traço da falta. É a perda do ser operada pela ação do significante. Esta é a parcela 
do vivo que se perde ao ter acesso à linguagem. Para tanto, temos o efeito de borda sobre duas faltas, uma simbólica, que ora tratamos pelo significante, e outra real, dada de saída pela perda do ser, justamente por ser sexuado.

A barra que divide o sujeito é a do recalque, da castração, da impossibilidade do significante representar plenamente o significado, posto que o referente é abandonado para tornar a significação possível. A barra do recalque é a mesma marca que confere ao sujeito a impossibilidade de representar-se plenamente pelo significante sem o efeito de afânise, de desaparecimento.

O desenvolvimento da teoria do narcisismo proposta por Freud impôs uma leitura absolutamente original da constituição do sujeito e suas relações com os objetos, justamente por tomar o eu como objeto de investimento da libido. Lacan destaca que o eu é uma forma de constituição dos objetos, tendo a particularidade de sê-lo a partir do semelhante e de modo especular. Há, de fato, no eixo (a - a') uma superposição das imagens. No plano do espelho há a simetria dos dês ego e de seus semelhantes. A desigualdade interpõe-se e instala-se pelo muro da linguagem. A esfera imaginária do (moi), deste $e u$ verificável, e do semelhante confere a ambos o estatuto de objeto.

Lacan atribui ao $e u$ a função significativa no discurso, pois sendo imagem está preso à cadeia de símbolos. A montagem do eu é possível pela ação do significante na carne. $\mathrm{O}$ significante pode então representar o sujeito, esse desencarnado, para outro significante. Temos o inconsciente estruturado como uma linguagem e o sujeito efeito do significante.

Quando Lacan (1999, p. 153) compara o inconsciente à tipografia é para acentuar que pode uma letra faltar. É precisamente no modo como se articula esta falta que a lei simbólica pode ou não operar. O significante está no campo do Outro e deve, em relação a outro significante, representar um sujeito, constituindo este Outro um terceiro termo essencial quando alguém fala.

Temos então três tempos. Um primitivo, onde o sujeito identifica-se imaginariamente com o objeto do desejo da mãe. Neste momento a criança é impotente frente a este Outro que ora está presente, ora ausente. Assim, o falo como objeto desejado pela mãe assume um lugar privilegiado na dialética subjetiva, pois é em torno dele que o sujeito vai se organizar. Mesmo sobre a égide do imaginário, o símbolo e a lei já se fazem presentes, uma vez que o falo é um 
objeto metonímico situado na cadeia significante, chave lógica que nos permite ascender ao segundo tempo.

O segundo tempo é marcado pelo encontro do sujeito com a lei, mesmo que ainda sob sua expressão imaginária. A percepção de que a mãe deseja um outro objeto situa este mesmo objeto no campo do Outro. É necessário que haja uma proibição no desejo da mãe para que o filho salve-se de ser este objeto e possa ser um sujeito. Há uma nova ordem em funcionamento: a mãe não é completa e ainda está submetida a uma lei. A relação com o pai é a entrada dos Nomes-do-pai, que tem na metáfora paterna sua máxima expressão como significante. É a ruptura com o lugar ideal que a criança pode, como falo, ocupar no desejo da mãe que possibilita o terceiro tempo, um tempo de identificação com o pai.

O terceiro tempo é marcado pela identificação ao Ideal do $e u$, identificação com aquele que tem o falo. Esta operação é estabelecida pelo significante. A cadeia significante está presente desde as origens como Outro e faz suas exigências à subjetividade, impondo uma barra ao Outro em sua constituição. Temos o declínio do complexo de Édipo quando a identificação possibilitada por aquele que tem o falo opera no sujeito. Este, se masculino, pode reclamar para si um falo; se feminino, vai situar-se ao lado daquele que é suposto tê-lo.

O significante fálico surge precocemente na medida em que é necessário abordar o desejo da mãe e, quando lá se toca, este lugar já está ocupado. Então para o ser humano ter acesso ao desejo é necessário, de saída, suportar a perda imposta pela ausência de objeto. Por isso que o significante tem relação com a falta de objeto.

Há uma lei imposta e esta relança o objeto para mais-além de um ponto tangível. O objeto do desejo é irrealizável posto que é causa de desejo. O Nome-do-pai garante que haja uma lei, ordenando os significantes na medida em que faz do falo o ponto de basta. Se o gozo deve contornar o falo operando, necessariamente, uma perda, para nesta fazer-se o circuito pulsional, é fundamental para tanto suportar a frustração da fraqueza que o falo representa. $\mathrm{O}$ falo traz a pecha de ser marcado pela impotência de ser realmente o objeto, no máximo um substituto canhestro.

A reprodução sexuada impõe às espécies que evoluíram para este modo de reprodução a morte do indivíduo, testemunhada pelo que a biologia celular descreve como apoptose. O sexo atinge o vivo pela via biológica, já o sexual é introduzido no sujeito através 
das marcas da falta pela via do significante. Não somente uma, mas duas faltas se sobrepõem quando se referem ao sujeito. Como vimos, o sujeito depende do significante que está originalmente no campo do Outro. À falta de significante acresce-se a falta originária, real, imposta pela condição de sexuado. É a perda real que a sexualidade impõe à vida. Neste sentido que o objeto da pulsão, objeto (a), suporta a emersão do sentido do sexo, arauto da presença da morte, pela função mesma do significante.

Chegamos então à proposição de que o aparelho psíquico é um aparelho de linguagem, desenvolvido para aparelhar o gozo, este resto insistente que nunca se inscreve no aparelho psíquico. Sua existência é denunciada justamente no que claudica na fala, pois é na ausência de representação que o gozo fala, no momento que ascende a uma tradução, fala de outra coisa. Eis a mola da metáfora; este algo que vem do real como o (a).

A diferença dos sexos é encarnada pela anatomia dos organismos vivos. O organismo é dividido em dois sexos, macho e fêmea, mas isso pouco acrescenta à compreensão da escolha dos parceiros. Deste modo, temos na significação da diferença dos sexos a melhor explicação para o desejo no humano, ou seja, como se situar frente à castração. Essa significação, particular para cada sujeito, traz no Outro os nomes de cada cultura. Ser homem ou mulher é, antes de uma determinação do cromossomo, uma resposta ao Outro. Temos no apelo aos instintos uma franca insuficiência explicativa pertinente à própria natureza do objeto causa de desejo, este objeto (a).

A cultura encarrega-se de oferecer objetos, unindo o desejo sexual à linguagem sob a forma metonímica. Quando se chega a um objeto, aquele propalado como derradeiro, este, natimorto, já está superado por outro, enfim, o prometido. Percebe-se um deslocamento sem ponto de basta, cuja substituição de objetos não possibilita significação possível. Deste modo a cultura pluraliza a oferta, sempre deslocando de um objeto ao outro, proporcionando contorno à falta camuflando na produção, no uso e na transmissão dos objetos a insanável divisão.

Os elementos conceituais que possibilitam a sustentação do conceito de gozo estão presentes desde o início da teorização da psicanálise. Podem ser identificados já precocemente nos modelos de aparelho psíquico da Carta 52 e do Projeto... - onde se desenharam o modelo da perda estrutural do objeto, ou seja, perda de gozo. Destacamos que o objeto complementar, 
alcançável pela via dos instintos é perdido, mas perdido por estrutura, não por experiência, para o falante, leva Rabinovich (2004) a afirmar que o vivente é "presa da linguagem”. Em contraste, temos a afirmação de Diamond (2010, p.67) que diz "a palavra falada que nos fez livres". Ora, mais do que uma contradição, vemos um ponto de convergência: a palavra falada libertou o homem da Natureza e o aprisionou na linguagem.

Quando a linguagem barra o sujeito pulsional (S), fazendo-o sujeito barrado (\$), escapa-lhe um resto $(a)$. Perda fundamental do freudismo, inaugurada a partir do trauma, nascedouro do que mais tarde evoluiria para a teoria das pulsões e suporte do gozo. Esta perda será a matriz e o desencadeante de toda a repetição e da insistência da repetição. O que levará Lacan a afirmar que toda pulsão é pulsão de morte. É o resto nunca simbolizável que pressionará continuamente o aparelho psíquico. Por ser a psicanálise a única ciência que trata do conceito de gozo, este só é alcançado teórica e clinicamente somente por meio dela. Acessado pela via da palavra, justamente por estar fora dela, conforme a demonstração cabal da relação do sujeito com o significante e seu resto, que escapole para fora da cadeia significante assumindo o lugar de objeto causa. Podemos afirmar que como conceito o gozo só existe para a psicanálise e como experiência, só para o humano.

Portanto, o significante só terá como efeito representar o sujeito para outro significante, como nos ensina Lacan, se antes houver a ação do Outro (linguagem) subtraindo o gozo e inaugurando um sujeito dividido que pode, enfim, equivocar-se. Dito de outra forma, ter o inconsciente como sintoma da perda de gozo.

A característica fundamental de o inconsciente ser feito de equivocidade (significantes que deslocam de uma cadeia a outra) é ter a garantia da inexistência de um significante que o defina. Portanto, temos o sujeito do inconsciente dividido pelo significante, sem conseguir no significante sua significação. O significante apenas o representa. Por consequência, tiramos que a interpretação do inconsciente não é a explicação (significado), mas sim o desvelamento da posição do significante na cadeia associativa. Assim, temos no inconsciente a revelação de que o ser falante não só habita a linguagem como é habitado por ela. O inconsciente é um Outro que guarda com o sujeito uma peculiar relação de alteridade, pois não está nem fora nem dentro do sujeito. Não há barreira entre o que é do sujeito e do universo simbólico no qual está inserido. 
Como falamos anteriormente, para Freud a pulsão é um conceito limite entre o psíquico e o somático. Portanto, não está propriamente em nenhum desses campos. A pulsão é representada no inconsciente pelos representantes pulsionais (Vorstellungrepresentanz), que, com Lacan, podemos chamar de significantes. De onde concluímos que são os representantes da pulsão que estruturam o inconsciente como uma linguagem. Ora, se adotarmos que o real é a energia pulsional, como nos propõe Quinet, (2003, p. 47) "energia que se presentifica como satisfação pulsional ou gozo do sintoma", podemos dizer que pulsão é o conceito limite entre o simbólico (Outro) e o real (irrepresentável).

Portanto, temos que os representantes pulsionais constituem o inconsciente, fazendo, então, recalque e inconsciente conceitos correlatos e visceralmente imbricados. Precisamente por isso, recorremos no início deste trabalho à antropologia (o que aqui poderíamos chamar de nossa mitologia) para resgatar as origens do animal homem e nela assentar as marcas do recalque para o estabelecimento do inconsciente, da humanidade. O recalque sela o fim dos instintos e marca uma recusa lógica da pulsão habitar o inconsciente, legando ao inconsciente a fixação dos representantes pulsionais. A linguagem do inconsciente é a linguagem da pulsão. Temos assim que a psicanálise opera por meio da linguagem (simbólico) sobre o gozo (real) justamente por ser a pulsão o conceito que permite articular os registros do simbólico e do real.

Assim, conta-se a história dos sujeitos: passeando pelos significantes que o marcam ao longo de sua existência. O desejo é precisamente o vetor, a seta $(\rightarrow)$, que vai se deslocar de um significante $\left(S_{1}\right)$, representado nas origens pelo desconforto da necessidade num traço perceptivo, para outro significante $\left(S_{2}\right)$, representado pela traço do objeto que satisfaz. É o encontro da fome com o seio na mítica primeira mamada do bebê.

Deste modo, constitui-se a articulação de desejo e demanda. Segundo o modelo freudiano, a demanda é a reivindicação da restituição de um estado anterior de suposta completude. Suposta pelo sujeito inaugurado pela falta, pelo trauma de sua incompletude. A demanda é justamente a demanda de o sujeito não ser, pois ser sujeito implica em perda, em falta, em mal-estar, em desconforto de estar vivo. O desejo seria então a busca, pois ao articular sujeito e significante, algo fica "fora de significação, fora de sentido" (FILHO, 2008, p. 37). A trajetória que visa reencontrar o objeto perdido, não pela experiência, mas pela estrutura lógica da constituição do sujeito, é tida como desejo. Percebemos, então que o 
desejo tem a ver com movimento, portanto, aproxima-se ao que Freud entende por pulsão erótica. Quando falamos, então, de desejo, temos que o objeto referido na equação, por estrutura lógica, é objeto causa, inexistindo então o objeto do desejo.

Como o bicho homem produziu próteses (ou seja, trabalhou para tanto e, neste engenho, há um saber) e com elas se relacionou de modo irreversível, modificando a si e à natureza, esta já não pode dar respostas às "necessidades" humanas, pois são de outra ordem, são outra coisa. A fala cria um universo simbólico que solapa a lógica da necessidade. O ser falante não encontra seus objetos na natureza. Estabelecendo neste novo campo o trabalho como meio necessário de acesso ao que mata a fome, ao que rebaixa a tensão pulsional. Portanto, o enunciado da fala do sujeito, ao contrário da ação do animal, não mira o objeto e sim ao Outro.

Lembremos que o inconsciente é feito de representantes pulsionais recalcados, ou seja, pulsão erotizada, permitindo acesso ao gozo-fálico, "gozo na e pela linguagem" (DUNKER, 2002, p. 41). Percebemos que a pulsão como uma demanda inconsciente que implica o corpo, uma vez que está entre o psíquico e o somático, gera demanda de trabalho ao aparelho psíquico. Então temos o desejo como alteridade ao sujeito e condição de possibilidade de o mesmo se destacar desse Outro. A pulsão, representada por $(\$ \diamond D)$, implica no apagar do sujeito da medida da tensão existente entre junção/disjunção com a demanda do Outro. Daí conclui-se que o pulsional é acéfalo (sem sujeito) e que o desejo pode ser uma saída do massacre do Outro. A articulação da castração com este gozo do Outro é que possibilita a assunção do desejo, justo nos termos da fantasia. Sendo assim, o desejo é a defesa contra o transbordamento que levaria ao gozo. O desejo é a proibição e a garantia do limite no gozo.

Até aqui, observamos a assunção do desejo como uma das válvulas reguladoras da interferência do gozo no ser vivo. O desejo dá ao gozo um limite/tratamento possível. Mas o desejo porta justamente em seu seio o mal-estar das renúncias pulsionais. A solução é ela mesma aflitiva, pois coloca o pacto edípico, uma concessão forçosa à castração, à força do Outro, como condição de possibilidade de o arranjo ser sustentável. Sustentável, porém, sempre ameaçado, pressionado. 
Claramente percebemos que estão em jogo aqui elementos da constituição subjetiva, bem como elementos do laço social. Ou seja, estruturas de constituição e suporte do sujeito na civilização. Goldenberg (2006, p.12) resume assim: “toda psicologia individual é ao mesmo tempo psicologia social, pelo simples fato da presença inevitável do outro, que entra em cena como modelo, objeto ou adversário". O desenvolvimento humano se dá por meio de uma profunda dependência do organismo com o Outro, com o campo social. Portanto, embora fonte inesgotável de sofrimento, o sujeito o é, e se salva do excesso mortífero do gozo, através do Outro.

Deste modo, para pensarmos os arranjos sociais, temos na ideia de Contrato Social (Hobbes, Locke, Rousseau) uma importante referência para o direito. Assim como as noções de organização Social, de Estado e Segurança Jurídica, temos o Contrato Edípico (PELLEGRINO, 1983) como pedra fundamental da constituição do sujeito na sua relação com o campo social. Ideias pautadas na noção de proporção e relação de homem para homem. À sedimentação de mecanismos psíquicos que já são fundados e fundantes na renúncia pulsional, assentam-se os valores do pacto social, cuja tônica recai sobre a proporção das relações e não na anulação das diferenças. Ou seja, o discurso enquanto laço social é político.

No artigo de 1913, Totem e tabu, Freud resgata um ponto importante da teoria de Darwin sobre os agrupamentos humanos para estabelecer, a partir da psicanálise, uma leitura original das bases da civilização como tratamento do gozo. Foi assim no mito estruturante da horda primeva e das sociedades totêmicas: Mata-se o Pai primevo, terrível e gozador, aquele que tudo podia, para viver sem tudo poder, mas com acesso a alguma forma de gozo. Um gozo parcial acessível a todos, mesmo, e justamente, regulado pela Lei (gozo fálico). A incorporação do pai, comendo-lhe a carne, assimilando sua força, é a rendição de uma homenagem ao pai morto, edificado pelo seu nome: Nome do totem, da tribo, da família, da Lei.

Esta comunidade estabeleceu seu pacto social renunciando à vingança e glorificando o pai morto, agora despersonalizado e incorporado, na adesão à Lei. Esta operação foi possível em decorrência do pacto edípico, cujo mandamento é sustentado pela frustração traumática e pelo banho de sangue que fez do Pai primevo um nome, uma Lei. Com isso, Freud chega mesmo a afirmar que o "sistema totêmico foi, por assim dizer, um pacto com o pai" (FREUD, 1913, p. 148). Portanto, as instituições humanas estão na base e na própria 
condição de possibilidade de tratar o gozo e evitar a reivindicação do lugar de gozo pleno do pai da horda. O pacto social, ou seja, a lei, regula as relações entre os irmão, legando a força paterna às instituições sem, contudo, cometer o equívoco de "supor que os impulsos hostis inerentes ao complexo-pai foram completamente silenciados durante esse período de autoridade paterna revivida” (FREUD, 1913, p. 153).

A civilização é feita a partir da renúncia pulsional, portanto, o mal-estar decorrente dessa renúncia é o mal-estar dos laços sociais. Lacan organiza o mal-estar na figura dos discursos, pois discursos são modalidades do laço social estruturados pela linguagem. Assim, podemos assumir que o laço social é uma forma de aparelhar o gozo e estabelecer relações entre as pessoas.

O laço social é uma das saídas para equilibrar a cara fatura das renúncias pulsionais. Revindicar um retorno mítico ao estado de plena satisfação é o fatal retorno ao organismo, com o seu correlato desenlace do Outro (ruptura e/ou recusa da castração). No sentido pessoal, é a desmontagem do sujeito através da ruptura com o gozo-fálico, cujo efeito é mortífero. No campo social, é o esgarçamento do tecido social com a precarização das instituições e a decorrente desimplicação do sujeito com o coletivo em atos comparáveis à perversão ou à loucura. É a corrupção do homem e da sociedade denunciada por Reale (1998).

Pensamos, então, que uma sociedade que fracassa menos - pois todo arranjo é uma forma de fracasso, o que não quer dizer que seja ruim - na sua missão civilizatória deve buscar instituições (por serem despersonalizadas, diminuindo a agressividade imaginária) que exerçam bons e eficientes inibidores e que possibilitem caminhos razoáveis de satisfação substitutiva, ou seja, meios do sujeito estar implicado com seu desejo num arranjo conservador do campo social. Pois, com o enfraquecimento da implicação subjetiva no discurso, aumentam os efeitos da identidade coletiva, ou seja, ocorre um enfraquecimento do Outro e um retorno ao narcisismo das pequenas diferenças (FREUD, 1921).

Esta lógica empurra ao condomínio no sentido do social e ao sintoma, no particular. Dunker (2015) afirma que a lógica do condomínio tem por premissa a exclusão do que está "fora do muro", dos limites que separam os outros, criando o efeito de alienação da tensão desse lugar cercado com seu exterior, articulando, então, três momentos da fantasia e um do sintoma no processo denominado condominização. O destaque dado a isso que podemos 
ilustrar como mau arranjo, ou fracasso do campo social, implica na insuficiência do sintoma em apresentar angústia e no recurso à fantasia e exclusão do outro como solução de fantasia para o sofrimento da ameaça dos povos bárbaros (DUNKER, 2015, p. 55).

O caminho do desenvolvimento cultural é produto e produtor desta contínua afetação, que estabelece nos laços sociais nodos de tratamento do excesso de gozo. Os arranjos são sempre fracassados, pois não há cura do inconsciente, mas existem arranjos melhores que outros. As culturas conseguiram ordenar o impulso predatório estabelecendo Leis cujas representações são institucionais. É justamente nestas instituições que estão depositadas as possibilidades de calibrar a eterna tensão entre o certo prejuízo da renúncia de gozo e a satisfação pulsional possível. Para o analista, o ato. Para o cidadão, a política. 


\title{
1. A ORIGEM DA PULSÃO OU OS MITOS DA ORIGEM
}

\author{
(...) o maior reducionismo é o que \\ propõe o discurso que pretende dar conta das \\ questões relevantes a partir, unicamente, do seu \\ próprio ponto de vista.
}

Doris Rinaldi

Pulsão é um dos conceitos fundamentais da psicanálise. Nos anos de 1890, o termo trieb começa a aparecer nos textos freudianos. Procuraremos a seguir destacar os precursores da pulsão, para nos capítulo seguinte desenvolver do circuito pulsional em Freud.

Iniciamos a argumentação por caminhos um tanto especulativos em busca das origens da pulsão. Para fazê-lo, iniciarei esta aventura explorando a "trilha dos nossos ancestrais", já tomando de empréstimo os termos de Dawkins (2009).

Como é sabido, a tradução clássica da Imago optou, inicialmente ${ }^{1}$, pelo termo instinto ao invés de pulsão. Partiremos deste ponto. Não pela exegese do termo, mas pela exploração do momento em que nos libertamos dos instintos.

O próprio uso consagrado da língua nos dá elementos suficientes para afirmarmos que a cobertura semântica do vocábulo instinto é inadequada para tradução do conceito de trieb. De acordo com o Dicionário Houaiss da Língua Portuguesa (2004) temos por definição de instinto, dentre outros :

1. Impulso interior que faz um animal executar inconscientemente atos adequados à necessidade de sobrevivência própria de sua espécie ou de sua prole (i. de nutrição, de copulação, de migração, de nidificação)(i. sexual);

\footnotetext{
${ }^{1}$ A nova tradução reviu esta opção.
} 
2. Padrão inato, não aprendido, de comportamento, comum aos membros de uma espécie animal (abelhas fazem suas colmeias sempre iguais por i.);

3. PSIC. Esquema de comportamento herdado, próprio de uma espécie, animal, que pouco varia de um indivíduo para o outro no tempo e que parece cumprir uma finalidade;

4. $\quad$ Freq. Impulso interior, independente da razão e de considerações de ordem moral, que faz o indivíduo agir, esp. Se a ação é anti-social (um homem de baixos i.)(não ceder aos $i$.).

Observemos que os usos do vernáculo referem-se ao inato, automático, padrão e com pouca ou nenhuma variação entre os indivíduos da mesma espécie. Somente no uso quatro notamos a infiltração de valores sociais/morais.

Os instintos estão fortemente amarrados à ciclacidade, tendo sua manifestação acionada por estímulos intermitentes. O instinto é reativo a um estímulo, sendo desencadeado por ele. Na ausência do estímulo, o instinto não exerce pressão sobre o organismo. Até aqui, todas as espécies estão regidas pelas mesmas regras, sofrendo pressões de mesma natureza. A evolução das espécies seleciona segundo as regras da natureza. Sobrevivência e reprodução balizam todos os viventes. Em virtude do desenrolar da seleção, um "macaquinho metido a besta" mudou a regra do jogo. A evolução da nossa espécie criou um evento bastante peculiar e até então original dentre todas as espécies existentes (DAWKINS, 2009, p. 55-57), o chamado Grande Salto Para a Frente (DIAMOND, 2012). O que viria a ser isso?

Passamos milhões de anos, na forma antropoide, como macacos habilidosos, mas por volta de 40 mil anos atrás uma ruptura radical apareceu. A partir daí, surgiram as artes, as lamparinas, os instrumentos específicos, a agricultura, o pastorio, o comércio, a escrita, o iphone e não paramos mais! A intervenção no meio ambiente foi, e é, tão forte que podemos afirmar que a seleção não é mais somente natural, evoluímos em um novo meio: a Cultura.

Segundo achados arqueológicos, nossa espécie já tinha atingido o desenvolvimento anatômico e cerebral moderno, mas permaneceu com hábitos primitivos e culturalmente inerte por muito tempo. Estes hábitos pouco se distinguiam dos de outras linhagens da espécie Homo contemporâneas a nós, ou dos grandes símios. Ou seja, embora produzíssemos sons específicos (palavras) com intenção e eficiência de comunicação e manuseássemos alguma tecnologia, não éramos mais espertos que os "outros macacos", nem fazíamos nada que eles 
não fizessem. Então não é só o uso intencional da linguagem e de instrumentos que fizeram a diferença.

Só para ilustrar, podemos citar as observações de grupos de macacos modernos que emitem sons distintos para avisar ao grupo da presença de um predador que vem de cima (águia) ou de baixo (leopardo), para alertar os membros desavisados do clã da ameaça e orientar a rota adequada de fuga. Ou ainda, sobre o uso deliberado de sons referentes a aproximação de um predador, na ausência real deste, com a finalidade de dispersar todos os indivíduos quando um clã se encontra em franca desvantagem em uma batalha com um clã rival.

Bom, então não foi a anatomia nem os genes que determinaram o Salto. Alguma coisa aconteceu, pois não saímos da idade da pedra por falta de pedra - parafraseando o Xaque Yamini (2001). Conforme Dawkins (2009), algumas autoridades julgam que o Salto coincide com a origem da linguagem, tamanha foi a revolução ocorrida. As mudanças anatômicas necessárias para uma fala já estavam, contudo, conquistadas há pelo menos 40 mil anos, conferindo descrédito a esta hipótese. São fartos os registros arqueológicos e as relíquias presentes em museus dispersos por todo o mundo a atestar que utensílios e ferramentas eram comuns naquela época, embora muito rudimentares e com pouca especialidade (o mesmo objeto era usado para muitos fins). Argumentos contundentes de autoridades como Pinker (2004), desenvolvidos em trabalhos como Instinto da Linguagem, sugerem com vigor que a linguagem é mais antiga do que o Salto.

A hipótese, bastante razoável, sustentada pelos autores neodarwinistas é que o Salto pode ter se dado em razão de uma nova habilidade linguística: o uso de palavras com função apenas gramaticais (DIAMOND, 2010, p. 185), orações condicionais e o uso de palavras referenciais (sem a necessidade da presença ou existência do referente), possibilitando o surgimento do símbolo (DAWKINS, 2009, p. 57). Pensamos que a direção está correta. Tem a ver com a linguagem, mais adiante falaremos de como a estrutura de linguagem é constitutiva de uma nova ordem: a do sujeito. Mas por ora, ficaremos um passo atrás. Enfim, embora seja presente e incontestável a base genética, a mudança que abriu espaço para a humanidade foi impelida pela cultura nascente ao descortinar de um universo simbólico (DAWKINS, 2009, p. 53). A linguagem, com sua nova propriedade além-representação 
modificou a carne do ser vivo - mas não como estabelecem estes autores - com possibilidades superiores à atribuição de sentido e intenção.

Uma nova habilidade linguística demanda um novo aparelho de processamento. Certamente, o abandono do referente possibilita que os arranjos entre as unidades de representação linguística articulem-se entre si, criando uma infinidade de arranjos. Mas, o que está em jogo não é propriamente o referente, e sim a capacidade de o aparelho psíquico ser desenhado para trabalhar com representações. Portanto, ao conceber um aparelho que incompatibiliza percepção e memória (FREUD, 1950 [1895]), algo é logicamente perdido de maneira irrecuperável, e a subjetividade passa a ser organizada em um novo topos.

Perfeito, embora essa articulação seja consistente, propomos que não foi o abandono do referente que criou uma nova ordem. Para entrarmos no reino do psíquico, no qual uma função específica criaria um aparelho de linguagem, precisamos da articulação de um novo conceito. Antecipamos: pulsão.

Diamond (2009, p. 49) é categórico em afirmar que nossa ascensão à humanidade não foi diretamente proporcional a nossa mudança genética. Podemos recorrer à imagem da banda de Moebius para representar esta relação contínua de intri-extricidade da carne com a linguagem. Observamos que nos trabalhos de Dawkins e Diamond, por exemplo, não há referência às pesquisas de Freud. Em Miller e Pinker, sim. Destacamos, contudo que os referidos autores optam pelo uso do termo instinto (instict), ao invés de pulsão (drive). Esta escolha acaba por revindicar um aspecto adaptacionista da leitura original de Freud. Quando optamos por pulsão, e afirmamos, com Freud, que pulsão não equivale ao instinto, muito antes pelo contrário, denuncia a perversão do instinto pela linguagem. Sem entrar no mérito, oportunamente indicamos que muito da distorção da prática psicanalítica guarda relação com esta forçosa equivalência entre instintos e pulsão.

\subsection{Como enterramos os instintos?}

Os efeitos da linguagem, elemento extrínseco ao ser, modificou o corpo do vivente, naufragando os instintos. A linguagem é fora do organismo, mas este só é humano através 
dela. Mais à frente, quando discutirmos a topologia e a constituição do sujeito, retornaremos a este ponto.

No intuito de abordar esta hipótese, os estudos baseados em evidência são obrigados a conviver com um problema: a linguagem não deixa fóssil e é evidente que a escrita foi um incremento tardio se pensarmos no Salto. Para muitos campos existe um desconforto na adoção e exploração de suposições, mas aqui podemos nos arriscar sem muitos constrangimentos.

Propomos que o incremento da linguagem nesta nova função psíquica destacou o homem de sua natureza. Mas como enterramos os instintos? Diamond (2010) destaca três grandes mudanças que separaram nossos ancestrais dos grandes símios e os aproximaram do que entendemos por homens modernos. A primeira mudança foi a adoção da postura ereta. A liberdade dos membros anteriores possibilitou uma profunda modificação nos hábitos, destacadamente a possibilidade de confecções de ferramentas, que radicalizaria as possibilidades de o homem modificar o meio ambiente. A segunda mudança seria a divisão de nossa linhagem em duas espécies distintas. Duas espécies vivendo na mesma área devem realizar papeis ecológicos distintos e normalmente não se reproduzem entre si. A terceira foi o uso regular de ferramentas e a transmissão de seu uso e confecção.

Coutinho Jorge (2008, p. 163) relaciona a bipedia e as contribuições da psicanálise sobre o inconsciente (sexualidade e linguagem). Podemos, sem correr o risco de excessos, atribuir ao inconsciente, justamente por articular sexualidade e linguagem, a característica mais peculiar da nossa espécie. Perceberemos ao longo deste capítulo nossos precursores, mas o êxito atual da nossa espécie é devido as nossas qualidades únicas e sem precedentes. Um acidente libertou-nos dos instintos nos dando as pulsões. Este acidente levou ao desenvolvimento de um aparelho psíquico que dividiu o campo da consciência, gerando a possibilidade de auto-reflexão, e estruturou-se como uma máquina de linguagem.

Estudos arqueológicos sobre as fezes fósseis dos homens primitivos revelam muito de seus hábitos alimentares. Daí, podermos inferir alguns de seus hábitos sociais. Os homens primitivos eram essencialmente caçadores-coletores. A alimentação era basicamente constituída por vegetais, pobres em nutrientes, com pouca participação de alimentos ricos em proteína. Ou seja, muito tempo destinado à alimentação e, vez por outra, aos vegetais, 
somava-se algum pequeno animal ou ovos. A organização social dava-se em pequenos grupos familiares nômades. Contudo, o homem primitivo já possuía cérebro maior, andava de pé e confeccionava ferramentas rudimentares. Ora, o cérebro grande, um aparelho fonador e a postura ereta eram a base da capacidade de articulação de uma linguagem falada complexa, mas era preciso algo mais. Com a modificação anatômica necessária para abrigar um cérebro maior, a prole diminuiu e o filhote humano teve que nascer antes do pleno desenvolvimento de seu sistema nervoso. Com estas características, ocorreu uma mudança no ciclo vital e no comportamento. Necessariamente, a infância ficou prolongada, criando a necessidade de organização social para caça, coleta, proteção e procriação (MORRIS, 2004). Textualmente, Diamond afirma que a fala teve uma importância crucial nas relações entre homem, mulher e sua prole (DIAMOND, 2010, p. 67). A característica de transmissão e desenvolvimento cumulativo destacou o desenvolvimento cultural do desenvolvimento genético. O Grande Salto Para a Frente lançou o homem para a humanidade.

Como já mencionado, a linguagem não deixa fóssil. Uma hipótese bastante consistente para entendermos porque ambas espécies de homens permaneceram com características semelhantes por muito tempo e, depois do Salto só uma vingou, é a perversão que o uso de palavras proporcionou nos instintos. Isso exponenciou a capacidade de criação de realidades, lançando o animal humano para um campo radicalmente novo no qual a operação de significante/significado ganha outra função além do símbolo para uma comunicação rudimentar. Esta tese é estimulante e dá vigor à nossa pesquisa do campo pulsional. Podemos imaginar a surpresa que Lacan teria ao conhecer as pesquisas com macacos na África, em seu sítio natural, que revelam o uso de sons distintos para referir-se a leopardos ou águias, usados sem a ameaça, aproximação ou presença destes predadores, com a finalidade de ludibriar um bando oponente e hostil de macacos da mesma espécie.

O abandono do referente já era uma conquista de outras espécies. O uso de sons com funções gramaticais tem o poder de transformar a coleção de palavras em histórias. A linguagem surge com principal característica da nossa espécie, pois cria a possibilidade que a evolução se dê por meios destacados da natureza, o homem evoluiria por seus próprios meios, muito mais rápido do que pela lenta ação da natureza (BOURGUIGNON, 1990, p. 9). Com a interferência no meio, principalmente nos meios de produção de alimentos, o homem primitivo ganhou longevidade, que permitiu a transmissão das habilidades adquiridas para as novas gerações. Não é difícil imaginar a revolução que a escrita guardaria para nós. 
A nova organização social, sustentada na anatomia moderna, remodelou o sexo e criou a sexualidade. Os hábitos sociais e o ciclo de vida desenharam a forma de cuidar da prole, obter alimentos e utilizar ferramentas (DIAMOND, 2010, p. 78). A ocultação do período fértil das fêmeas humanas assim como a menopausa são mostras que a função biológica da copulação não é a reprodução (DIAMOND, 2013). O abandono do cio, do instinto, lança a pulsão para suas características perversas e polimorfas (FREUD, 1905).

$\mathrm{Na}$ organização da sociedade humana, o estreitamento dos laços é fortemente dependente do sexo, que ganha características mais ou menos monogâmicas, sendo buscado de modo privado e constante. A seleção dos parceiros sexuais, célula nuclear da organização social humana, orientou-se para outros aspectos além do vigor e beleza físicos, indicativos sensíveis de saúde e fertilidade (MILLER, 2004). A seleção sexual buscou os cérebros. Os produtos da mente, como linguagem, sagacidade, generosidade, confecção de produtos, capacidade de intervir no meio e toda uma infinidade de possibilidades tornaram-se, por assim dizer, sexualizados. Ora, algum nível de regramento, repressão, teria de se impor para arrastar o sexo para a sexualidade e manter o homem cada vez mais nos meios de linguagem. Os estudos de Miller, no original A mente seletiva - como a escolha sexual influenciou a natureza humana, propõem que os produtos da mente humana são os poderosos atratores e determinantes da escolha de parceiros. O sexo não é mais condicionado aos feromônios, mas excitado pelo que a mente produz. Permita-nos aqui criar uma alegoria, um chiste: trocamos o macho- $\alpha$ das hordas simiescas pelo macho-Alfa Romeo das baladas. Não é um convite para pensarmos nas vicissitudes da pulsão, mais especificamente na sublimação? Bem como as propriedades de a libido recobrir objetos,ou ainda às relações constitutivas do Outro para o sujeito? Bom, deixemos isso para mais adiante.

Não é forçoso afirmar, pegando emprestado o conceito de Dawkins (1999), que a linguagem é o fenótipo estendido do humano. Devido ao desenvolvimento evolutivo da nossa espécie, alcançamos um cérebro e um aparelho fonador, cujo desenho é genético, capaz de influenciar/modificar o meio. Mais do que a fala, ou a habilidade de comunicação, a linguagem cria um novo meio, produz objetos onde nada havia e torna o homem fortemente dependente destes objetos. Munidos dessas novas características, os homens colocam uma verdadeira revolução em curso. As funções olfativas, extremamente importantes para os mamíferos, sofrem um importante decréscimo nas suas potências, uma atrofia mesmo. 
Os feromônios são sinais químicos de ação intraespecífica que promovem o reconhecimento sexual nos indivíduos da mesma espécie. Quando excretados desencadeiam respostas fisiológicas e comportamentais nos indivíduos presentes no raio de ação. A postura ereta afasta o olfato dos genitais, principais glândulas excretoras de feromônios. A atrofia da função olfativa acentua a perda do determinismo biológico. Com isso, o olfato dependente do ciclo periódico perde importância para a visão, função de estimulação constante, para o campo sexual (JORGE, 2005). Esta supressão leva o homem à sexualidade, desvinculando-a do cio e da procriação. É a hipótese freudiana sobre o recalque orgânico incidente sobre o olfato. O olhar passa a ter uma função com objeto da pulsão, como discutiremos adiante. Esta atrofia do olfato e a primazia do escópico inauguram o campo pulsional e o separa do sexual. Características que unem a sexualidade e o infantilismo (JORGE, 2005) passam a constituir no olhar a passagem do instinto à pulsão. Com a perda do olfato como primado sexual, características físicas fortemente referidas ao infantilismo exercem o fascínio no campo sexual. É só olharmos a neotenia, cuja forma mais bem acabada, biologicamente falando, é o corpo da mulher (MORRIS, 2005). Esta mudança tem implicações também no que se refere ao ciclo de vida, pois modifica o nível de exigência para os parceiros sexuais. Só para lembrar, Darwin (2004), em 1871, argumentava de maneira vigorosa que a escolha dos parceiros sexuais atendia à seleção sexual, não à seleção natural.

As funções biológicas atendem a um ritmo e a eliminação da fonte de estímulo proporciona satisfação. A pressão do estímulo cessa quando o objetivo da satisfação é atingido. Com a pulsão é diferente. O estímulo, e a decorrente pressão, são constantes e impossíveis de satisfazer plenamente. O organismo que busca adaptação nada tem a ver com o aparelho que busca regulação nos termos de suas representações. A ação gerada para regulá-lo pode, inclusive, gerar comportamentos inadaptativos.

O alvo da pulsão é a satisfação. Os caminhos percorridos para buscar satisfação serão muitos, mas como o alvo só pode ser atingido com a cessação da fonte do estímulo pulsional e a pulsão é uma estimulação constante, o alvo é para não ser atingido. A tarefa impossível em sua plenitude, mas a satisfação parcial é bastante acessível. As vicissitudes da pulsão são meios de satisfação parcial da mesma. Ora, a impossibilidade da satisfação da pulsão realiza toda a plasticidade das satisfações parciais. $\mathrm{O}$ inconsciente freudiano demonstra que tanto as relações sexuais como os sintomas são vias distintas de realizar a satisfação parcial. Estamos 
então com Freud quando ele afirma que o sintoma é o ato sexual do neurótico (FREUD, 1905).

No circuito pulsional, a pulsão circula objetos na tentativa de satisfazer-se. Realiza uma satisfação parcial, mas revela que não será por eles ou neles que a satisfação ocorrerá. Como veremos adiante, a pulsão é demanda de trabalho ao aparelho psíquico, não estando propriamente nele. Os objetos são apenas representações que estão no aparelho psíquico com a possibilidade de alguma satisfação. Contudo, ao aproximar-se do objeto, aproxima-se também na real noção de insatisfação presente na ausência do objeto. Isso mais tarde será identificado por Lacan como uma dimensão do real. A fantasia, representantes da pulsão mais afetos, é o véu necessário para a satisfação parcial ser possível, sem que o desencontro proporcionado pela ausência de objeto libere muita angústia.

No artigo A Interpretação das Afasias, Freud desenvolve a tese contrária ao modelo localizacionista das afasias. Pensa-as como perturbações do aparelho de linguagem (OLIVEIRA, 1999, p.07). É importante observarmos que, neste texto considerado prépsicanalítico, Freud rompe com o campo neurológico e desenha o embrião de um modelo sustentado na representação. Toma a palavra como a unidade funcional da linguagem, e a descreve como uma complexa montagem de representações.

Vejamos o esquema psicológico da representação da palavra (modificado de $A$ Interpretação das Afasias, FREUD, 1977, p. 46, fig. 03,):

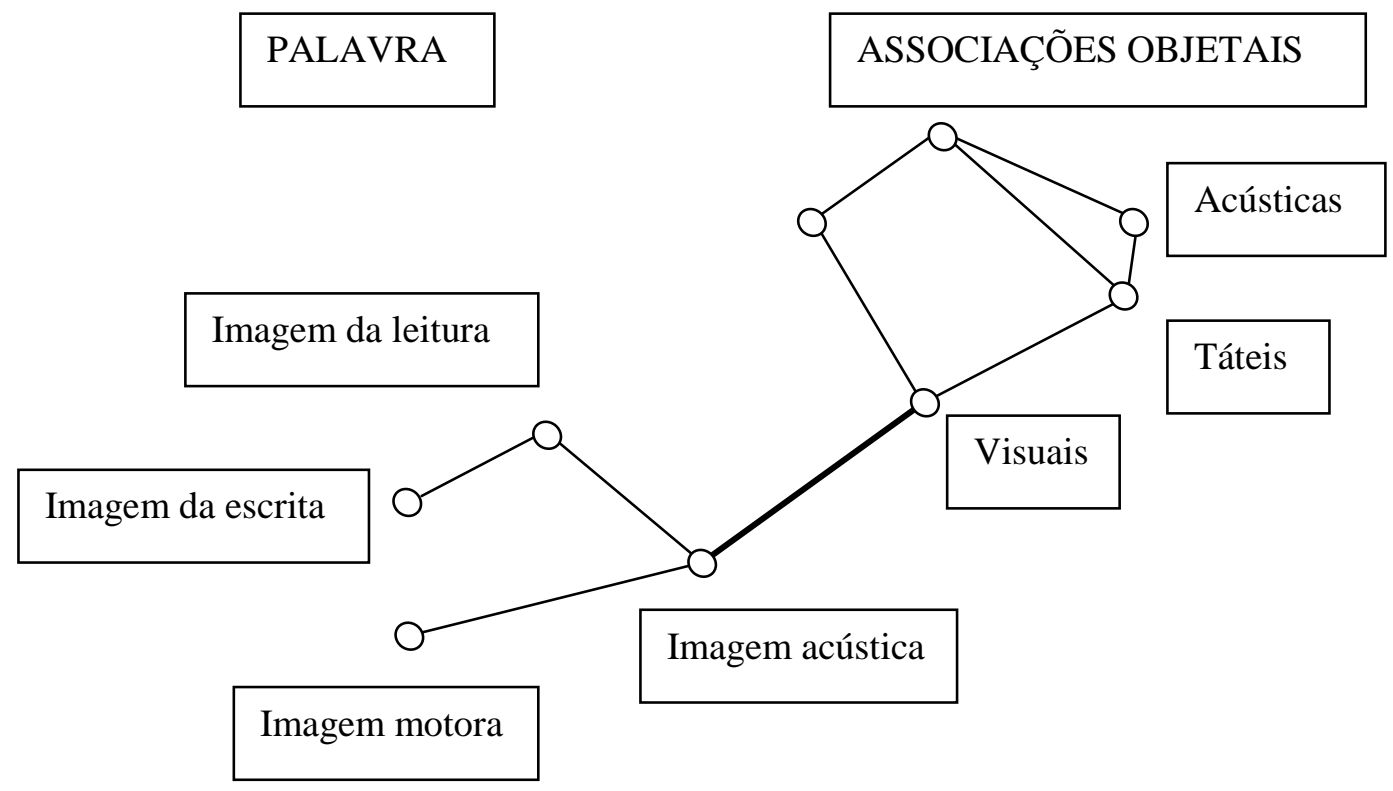


Segundo este modelo, a significação da palavra ocorre devido à ligação entre a imagem acústica da representação da palavra e a imagem visual da representação de objeto. Temos então um esquema psicológico da representação da palavra cuja imagem acústica representa a palavra e a imagem visual do objeto ocupa o lugar das associações de objetos. Como destaca Oliveira (1999, p.19), Freud aponta para a ruptura da relação palavra-objeto. Consequentemente, no processo de significação da palavra, o referente fica de fato excluído, pois não faz parte dos termos da operação, e a ênfase recai na relação do significante com o significado. Modificações na anatomia muscular do aparelho fonador, o que não deixa registro fóssil, podem ter levado ao controle e à variação de sons. Com o controle fino do som, a capacidade criativa foi desenvolvida lentamente, podemos pensar que foi "a palavra falada que nos fez livres” (DIAMOND, 2010, p.67). Buscaremos ao longo da pesquisa demonstrar que esta operação de linguagem, própria de um aparelho psíquico, contrário às teses neurológicas, foi desenhado a partir de uma operação que possibilitou um novo uso da linguagem.

Esta operação é o dobramento do inconsciente, do real sobre a carne, que possibilitou a saída do universo natural e a entrada da linguagem. Defendemos que o inconsciente, característica do falante, é que possibilita expandir nossa compreensão do Grande Salto para Frente. Sem o inconsciente, seríamos ainda macacos habilidosos.

Vejamos quais consequências tiramos disso e como a evolução do homem pode nos ajudar a compreender as origens da pulsão.

\subsection{A origem do homem: do instinto à pulsão}

Sempre que pensamos no desenvolvimento do Homem, na evolução, somos remetidos à imagem do macaquinho primitivo de braços compridos e corpo pequeno que, linearmente, sofre mutações até a forma acabada, tida como a mais evoluída, do homem em pé, de coluna ereta, com o corpo equilibrado e musculoso. 


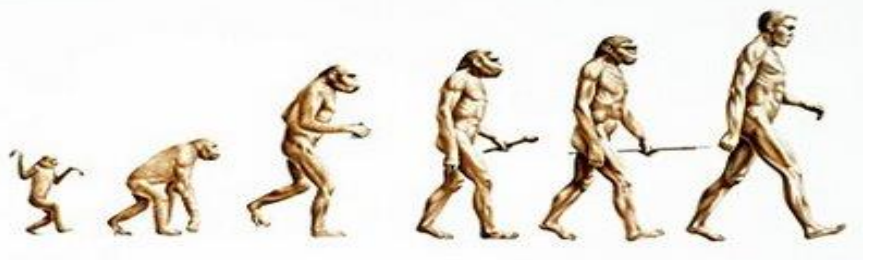

Nada mais falso! O desenvolvimento da espécie humana deu-se como um mosaico, não como uma linha. As mutações anatômicas, o desenvolvimento cerebral e a habilidade de confecção e uso de objetos também não foram sincrônicas e sequenciadas (BOURGUIGNON, 1990, p. 157). Além de tudo, não é mais possível crer na ideia que a evolução nos brindou com uma descendência privilegiada ou um fim projetado. Ora, pensar que a vida se organizou para chegar no homem é produto do supremo narcisismo humano! "A evolução alcançou muitos milhões de fins provisórios [...], e não há nenhuma razão além da vaidade [...] para designar qualquer um mais privilegiado ou mais culminante do que outro" (DAWKINS, 2009, p. 21).

As mutações anatômicas foram determinantes para o desenho do homem moderno, tanto para as suas características físicas, quanto psicológicas. O modelo de mosaico é mais competente para alcançarmos a ideia de precursores, que nos é cara para o desenvolvimento conceitual das origens da pulsão. O que são precursores? São formas rudimentares, tanto anatômicas quanto comportamentais, presentes em outros seres que no homem moderno atingiram organização e complexidade capazes de garantir o atual êxito biológico como espécie (DIAMOND, 2010, p. 11). Ora, abdicando da pretensiosa vaidade de sermos os homens tão diferentes e especiais, podemos buscar em dados etológicos e paleoantropológicos os tais precursores para alavancarmos a compreensão do complexo campo pulsional.

Na História Natural do Homem-1: O homem imprevisto, Bourguignon (1990) faz um minucioso trabalho demonstrando a profunda unidade das matérias existentes. Começa pela exploração dos elementos químicos básicos, presentes no universo em formação, chegando a nucleossíntese dos elementos, para dar início à aventura da vida pelo nascimento dos átomos e moléculas. Com um fôlego incomum, o autor passa pelas formas rudimentares de vida 
unicelular ao surgimento do homem. Vejamos em suas palavras como resume os estágios revelados por sua pesquisa (BOURGUIGNON, 1990, p. 45-46):

Alguém que fosse solicitado a indicar as mais importantes etapas desse longo percurso que leva das primeiras manifestações da vida até o homem, poderia, a meu ver, deter-se nas seguintes:

1) No início, há 3,5 bilhões de anos, aparecem as primeiras pequeninas células, os protogenotas, cuja informação genética rudimentar não está isolada por uma membrana, que se dividem diretamente (ausência de fuso mitótico) e não possuem mitocôndrias.

2) Há 2,5 bilhões de anos aparece o sistema enzimático da fotossíntese.

3) Há 1,5 bilhão de anos surgem grandes células aeróbicas, que têm grande mobilidade intracelular, um núcleo envolto por uma membrana contendo um genoma diplóide adquirindo mitocôndrias e, no caso dos vegetais, cloroplastos, e que passaram a se reproduzir por mitose.

4) Na mesma época, a simetria das populações celulares é rompida por sua divisão em células masculinas e femininas. A importância do papel da sexualidade na evolução jamais será suficientemente enfatizada.

5) Há cerca de 650 milhões de anos, por simbiose de um grande número de células, constituem-se organismos pluricelulares, em cujo interior as células se diferenciam funcional e estruturalmente. $\mathrm{O}$ mundo vivo se divide em um reino animal e um reino vegetal.

6) Ao mesmo tempo, surge um novo modo de emparelhamento com o meio: o sistema nervoso.

7) Em uma centena de milhões de anos, todos os grandes planos de organização são definitivamente estabelecidos, em particular o dos vertebrados, há 430 milhões de anos.

8) A terra é conquistada pelos vegetais, depois pelos invertebrados e finalmente pelos vertebrados.

9) A conquista do ar é realizada pelos insetos há 350 milhões de anos e pelas aves há 130 .

Levando em conta a idade do universo, só muito recentemente o homem iniciou sua aventura no planeta. Sua evolução seguiu a princípio os mesmos passos dos outros seres. Biologicamente nosso corpo físico evoluiu do mesmo modo e no mesmo ritmo das demais espécies. Contudo, o homem imprevisto de Bourguignon bem poderia ser chamado homem improvável. Nossos corpos continuam seguindo, em termos evolutivos, o ritmo da natureza, mas nossas vidas se modificaram numa velocidade jamais observada nos outros viventes. Continuaremos com nossos ancestrais para vermos como mudamos do meio natural para o meio cultural, abandonando os instintos e abraçando as pulsões. 


\subsection{Um dedo fez a diferença}

O aperfeiçoamento da espécie em seus ambientes leva ao desenvolvimento da necessidade de isolamento para diminuir a possibilidade de contágio com os vizinhos e a natural mutação das características adaptativas. $\mathrm{O}$ isolamento fica bem mais eficiente com o incremento de modificações e especializações no comportamento sexual de modo a impedir o cruzamento entre espécies diferentes, mesmo que aparentadas (MORRIS, 2004, p. 16). Assim, a evolução cuida de manter as espécies isoladas geneticamente sem a necessidade do isolamento físico/geográfico. Reparem que a natureza desenvolveu-se colocando restrições ao sexo. Mais adiante veremos como a função psíquica advinda com o uso da linguagem iria restringir o sexo, mas por meio de outra operação psíquica. A saber, o recalque.

A origem do homem e dos primatas remonta, com forte probabilidade, ao ramo dos pequenos mamíferos insetívoros contemporâneos dos lagartos terríveis. Seus corpos eram pequenos, com pernas e patas eficientemente desenhadas para mantê-los agarrados a vegetação e para impulsioná-los na locomoção por meio de saltos. Tudo leva a crer que o comportamento era arisco. Permaneciam abrigados nas florestas fechadas, trepados a árvores. A aventura fora das matas mais densas só começaria após o declínio dos grandes repteis (MORRIS, 2004, p. 20).

Com a exploração de novos ambientes fora das florestas, começaram as mudanças nos hábitos alimentares. Além dos insetos, as folhas, frutos e sementes começaram a fazer parte da dieta. Bem ao modo da evolução, este pequeno mamífero começou a mutar para um primitivo primata. As modificações fisiológicas e anatômicas possibilitaram uma visão melhor, cérebro maior e mãos diferenciadas. Os corpos foram crescendo, ficando mais pesados, caudas desenvolvendo e a locomoção evoluiu no sentido da bracejação. As especializações foram ocorrendo e um grupo ganhou maior massa corporal, podendo arriscarse no chão. Mais um ramo surgia! Dos macacos surgiam os símios.

A grande força da aventura evolutiva é a pressão da sobrevivência. Evoluir não implica um sentido romântico de que se evolui ficando melhor ou mais complexo do que a forma anterior. Evoluir é reproduzir-se e manter-se vivo, mesmo que isso implique em perda de características adquiridas com muito custo. $\mathrm{O}$ ambiente sofreu modificações 
importantíssimas. O clima mudou, encolhendo as florestas exuberantes. Desenhou-se assim o isolamento geográfico dos símios e o desgarramento de um parente que se locomovia de outra forma. Tinha pés estranhos, com o polegar anatomicamente diferente, pernas muito compridas e braços curtos. A torção do polegar dos pés possibilitou que este macaco adotasse a bipedia.

Esta pressão determinou uma empresa difícil, mas o resultado, além de imprevisto, revelou-se surpreendente! Arriscar-se no solo seria lançar-se em competição com outros animais, lenta e eficientemente desenvolvidos para sobreviver neste nicho. O impacto desse novo arranjo iria modificar não só os atores desta jornada, mas toda a ecologia do planeta.

A empreitada de exploração dos campos e de matas abertas colocou o ancestral do homem frente à possibilidade/necessidade de ampliar o cardápio. Trouxe também vários inconvenientes. Lembremos que a alimentação dos tempos das florestas já não era exclusiva de vegetais, frutos e sementes. Por ser descendente de insetívoros, constava em sua dieta a proteína animal. Quando nas árvores, insetos, ovos, filhotes e pequenos répteis compunham o cardápio. O cérebro, as mãos, a visão e o aparelho digestivo desenvolveram-se para dar conta disso.

No solo, essas iguarias estavam presentes, mas sem muito esforço podemos perceber que as possibilidades de ampliar a dieta se multiplicaram. Novo habitat, nova alimentação, novos hábitos... eis a máquina da evolução exercendo o que faz de melhor: pressão sobre as espécies. Lenta e naturalmente a seleção destacaria aqueles que de forma mais eficiente ampliassem as chances de sobreviver e de se reproduzir.

Podemos dizer que a curiosidade, traço infantil que o futuro revelaria como muito caro, somada a possibilidade de ampliar as opções alimentares, formaram a mola que separou os ramos dos símios e dos hominídeos. Os primeiros, já especializados na floresta, lá ficaram confinados. Os outros arriscaram mais. Começamos a adotar hábitos carnívoros. Não dava, por óbvio, para competir com os assassinos especialistas experimentados num ambiente hostil em igualdade de condições (quem duvida, pode tentar tomar um naco de carne de um leão, munido somente das próprias mãos). Começamos nos fartando com pequenos filhotes desprotegidos e/ou doentes. Diamond viu no homem primitivo uma proximidade maior com um chimpanzé habilidoso do que com um caçador perigoso (DIAMOND, 2010, p. 50), que 
povoa o imaginário narcísico da humanidade. Ficamos perigosos, muito perigosos, diga-se, aos poucos.

Os prolegômenos da humanidade colocaram os hominídeos num beco. Não desenvolvemos biologicamente as armas eficientes para a matança necessária de uma dieta carnívora. Como já havia assassinos especialistas ocupando este habitat, seria muito dispendioso esperar que nos equiparássemos a eles segundo as leis da mutação e seleção. Nem daria tempo. Não tínhamos uma visão voltada para a caça, não tínhamos garras e presas, nem a musculatura suficiente para tal empreitada. Entrar no nicho dos carnívoros e com eles competir por alimento levaria o hominídeo ou a extinção, ou de volta à floresta (para novamente competir com os símios). Outra opção seria entrar em equilíbrio entre os carnívoros e os símios nas franjas das florestas para desempenhar papel ecológico distinto, mas isso restringiria o cardápio que se abrira em novos potenciais.

A mudança do ciclo vital acarretou vantagens interessantes. Falaremos disso mais adiante. Por ora, continuemos com o avanço para os campos abertos e com a adoção dos hábitos carnívoros.

Para acessar presas que representariam alimentos com maior reserva de energia, tivemos que nos adaptar ao estilo de caça cooperativa, ao modo dos lobos e leões. Para superar as claras desvantagens de não ser equipado como carnívoros, a comunicação e o incremento de manobras mais complexas de caça desequilibraram a balança. A caça impôs a necessidade de comunicação mais exata e eficiente. Faltava pouco para a confecção de próteses que os hominídeos adotariam como característica da espécie. Sem garras, fomos às armas!

Percebam que quando falávamos da evolução na forma de mosaico não estávamos brincando. Uma dieta pobre em proteína leva à necessidade de alimentação constante, seja pastando ou coletando. Uma alimentação rica em proteína, ao modo carnívoro, leva a festins alimentares com grande ingesta de alimentos, longos momentos de ócio e a natural dispersão do grupo. A adoção da caça gerou alguns efeitos impressionantes não verificados em outros primatas. As fêmeas ficaram mais dedicadas aos cuidados com a prole. Continuavam coletando, mas como sistematicamente os produtos da caça abasteciam o bando, intervalos de ócio sem dispersão do grupo surgiram como estratégia efetiva de sobrevivência. 
O filhote humanoide é altamente dependente e pouco adaptado. Carece de longos cuidados específicos, sem os quais não sobreviveria. Com menor necessidade de alimentar-se devido ao acréscimo do valor calórico da dieta, e sem poder afastar-se das crias, começaram as primeiras conversas e atividades manuais de confecção de objetos. A mudança nos hábitos sociais levou numa só tacada à invenção do tempo e do trabalho. A presença deste novo predador levou ao deslocamento e a extinção das presas mais acessíveis. Assim, as expedições de caça ficaram mais longas e tiveram que privilegiar naturalmente presas maiores. Houve então uma divisão nos hábitos de deslocamento. Os grupos de machos caçadores deslocavamse e retornavam a uma base fixa com o espólio para compartilhar com os anciões, as fêmeas e crias.

Portanto, diferentemente dos predadores cooperativos existentes, os humanoides não abatiam as presas, se fartavam e o grupo dispersava-se. A atividade cooperativa seguia mesmo depois da matança. Evidente que a penetração no território de outros predadores, naturalmente melhor equipados, só foi exitosa com a suplência e a intervenção no meio. A natureza social dos primatas levou, pela via da alimentação carnívora, o humanoide a virar homem. Para competir pela sobrevivência, ou seja, evoluir e não se extinguir, o cérebro se fez mais forte que músculos e dentes. A coordenação de ataque, captura e abate, ficou mais complexa. $\mathrm{O}$ grupo comunicava-se e suplantava a natureza com próteses. O homem estendeu seu fenótipo para além dos genes. Este bicho só é humano se falar e carregar armas. Hoje é simplesmente impensável homem separado de suas ferramentas e códigos organizados como uma linguagem.

Diamond (2010, p. 46-47,) nos alerta que nossa chegada à humanidade não guarda relação direta e proporcional à mudança genética que nos separou dos grandes símios. $\mathrm{O}$ aumento do volume cerebral do Homo sapiens não gerou mudanças drásticas no estilo de vida e nem no uso e confecção de objetos. Mesmo com a base anatômica cerebral moderna as mudanças culturais foram muito lentas. Estamos diante de um enigma antropológico muito estimulante. Nosso material genético é apenas $0,1 \%$ diferente do de um chimpanzé. As diferenças são colossais. Mesmo equipados anatomicamente com cérebros modernos, permanecemos culturalmente inertes por um longo período. O que se passou? Parece que uma resposta possível tenha sido a base anatômica para uso de uma complexa linguagem falada, que aos poucos foi se desenvolvendo para uma entidade extracorpórea, logicamente anterior ao indivíduo, e, ao fazê-lo, proporcionou mudanças inimagináveis no macaco falante. 
Modificações na anatomia muscular do aparelho fonador, o que não deixa registro fóssil, podem ter levado à possibilidade de controle e variação de sons. Com o controle fino do som, a capacidade criativa foi desenvolvida lentamente, mas podemos pensar que foi "a palavra falada que nos fez livres" (DIAMOND, 2010, p.67).

Retomemos. Naquele ponto, a evolução abandona a natureza justamente por ter sido equipado por ela. A comunicação e a mudança de hábitos alimentares interferiram nos hábitos e muito mais agudamente no ciclo de vida. Abandonado o nomadismo, advindo com o caminhar terrestre, surgia o territorialismo. Como Morris observou, aqui está o limite entre a biologia e a cultura (MORRIS, 2004, p. 26). Nesta intersessão está o homem e o nascedouro do inconsciente, como desenvolveremos mais adiante.

O progresso e sucesso da espécie não dependeriam mais da genética. A cultura e seu meio de propagação, a linguagem, são os novos determinantes. A responsabilidade com a prole, com os parceiros sexuais e de caça, estendeu-se para intervenções no meio: abrigos, conforto, proteção, fogo, utensílios, e nunca mais paramos. Nasciam as famílias, com laços fortes e organizados por clãs. A necessidade imposta pela pressão da natureza uniu o grupo, criou responsabilidades entre os membros e com o território. Mas, o grito primitivo de ascender no bando, tomar para si as fêmeas e expulsar os machos concorrentes deveria ser sufocado por uma ação eficiente. $\mathrm{O}$ uso de armas impõe que o instinto assassino seja barrado, pois uma desavença poderia ser fatal para o indivíduo e, consequentemente, para o grupo. Os inibidores externos possuem eficiência limitada. Uma operação mais complexa e efetiva deveria acontecer para arrancar o homem da natureza e inseri-lo na ordem da cultura. Eis a base para uma atividade psíquica: o recalque e a Lei.

Morris (2004, p. 32) chama atenção para um importante aspecto anátomo-fisiológico, que nos é bastante esclarecedor sobre a precisão do recalque orgânico, proposto por Freud, e especialmente valorizado por Coutinho Jorge (2008, p. 44). Nos primatas a visão é muito mais eficiente e desenvolvida do que o olfato. Várias razões evolutivas justificam este fato. Vejamos algumas.

A origem primitiva do homem está num mamífero habitante das altas copas. Para um deslocamento seguro era mais importante ver bem do que cheirar ou ouvir bem. $\mathrm{O}$ investimento, em termos evolutivos, privilegiou os olhos, reduzindo as narinas e orelhas. A 
função destes órgãos sofre decréscimo. Além da locomoção, a visão ficou muito mais acurada para detalhes e cores, tendo desenvolvido estruturas mais eficientes para captura de detalhes estáticos. Comer comida estática demanda boa percepção de forma, cor e textura. Só para contrastar e acentuar as consequências da adoção de hábitos carnívoros, destacamos que nos predadores a visão é empobrecida na percepção de cor e detalhes, mais sensível à captura de movimento. O olfato e a audição são muito desenvolvidos e sensíveis, atuam inclusive compondo com a visão a percepção tridimensional de forma e distância. A alimentação dos carnívoros é monótona e pobre em sabor. Os primatas desenvolveram maior percepção de paladar e adotaram uma alimentação mais diversificada em consistência e sabor. Atentemos ao fato de o nosso paladar ser fortemente composto e influenciado pelas células do olfato. Esta atração natural por variação no paladar somada à parcial ineficiência na digestão de carne contribuiu para o desenvolvimento do cozimento dos alimentos.

Os hábitos alimentares influenciam muito a sociabilidade das espécies. O privilégio de alimentos estáticos e abundantes leva o grupo ao pouco deslocamento e ao convívio mais íntimo, já que não precisam procurar comida e têm a necessidade de comer o tempo todo. Esta proximidade leva o grupo a observar e controlar o comportamento social dos indivíduos do bando. A ausência de atividade cooperativa fortalece a competição e dominação. A rede de aliança entre os membros do bando é constantemente vigiada. Olhar o que os outros fazem pode ser vital no bando coletor não cooperativo, a atenção ficou mais difusa e dispersiva. Os primatas adoram um Big Brother!

Um caçador atua concentrado e com os sentidos fixados na presa até o abate. Depois de saciados, mesmo que mantendo alguma proximidade, o grupo de caçadores cooperativos não manifesta muito interesse pelos outros membros do bando. $\mathrm{O}$ sistema hierárquico é rígido e a necessidade cooperativa atenua a agressividade entre os membros. Mesmo porque todos os membros andam fortemente armados. As disputas são ocasionais, rápidas e não costumam ser fatais entre os membros do mesmo bando. Os primatas, por terem alimentos abundantes e estáticos, frequentemente os perdem ao distraírem-se com alguma macaquice de outro animal do bando. Brigam muito entre si e modificam alianças com muita frequência.

Conforme discutimos acima, o homem se desenvolveu com base num sistema de precursores de origem primata, coletora não cooperativa, e com a adoção dos hábitos de outro sistema, caçador cooperativo. Tinha tudo para dar errado! O equipamento para caça e 
sobrevivência no solo não era o melhor. Audição curta, com orelhas fixas, olfato frágil, sem garras ou presas, um físico que não atendia às necessidades de fundistas ou aos arranques necessários para as emboscadas. Atenção desfocada e interesse maior pelos outros membros do grupo do que pelas potenciais presas.

Uma mutação levou a uma mudança estrutural na anatomia quando descemos ao solo. As mãos desenvolveram-se num sentido e os pés no outro. Um dedo fez toda a diferença, pois a torção do polegar levou a posição ereta. Soma-se ao equipamento um aparelho fonador com muitas possibilidades e um cérebro grande. Mais alguns ajustes e mudaríamos tudo!

Neste mosaico, a estrutura social e os hábitos de caça influenciaram o ciclo de vida e valorizaram características infantis. A neotenia, processo pelo qual características infantis são preservadas na idade adulta, passou a ser enormemente valorizado. $O$ ritmo de desenvolvimento deixou de ser uniforme, ou seja, ficamos seletivamente infantis. $\mathrm{O}$ desenvolvimento sexual ficou mais rápido do que o cerebral. Preservamos a curiosidade dos pequenos mamíferos por toda a idade adulta, observemos que até os dias de hoje o adulto humano brinca em seus jogos simbólicos. A infância ficou mais longa, tornando-se, inclusive, uma das chaves do processo de aprendizagem. Com isso, garantimos um lugar para a transmissão da experiência, pois os mais novos ganharam mais tempo sob os cuidados dos mais velhos.

A infância prolongada fez muitas exigências para as fêmeas e criou situações bastante originais. Além da fixação da moradia, houve secundariamente uma divisão artificial do trabalho, não uma especialização no sentido evolutivo do termo, mas uma incipiente organização social do trabalho.

Os estudos sobre os caçadores-coletores indicam que, mesmo tendo adquirido hábitos carnívoros, grande parte da alimentação ainda permaneceu proveniente do trabalho de coleta das mulheres (DIAMOND, 2010, p. 50). A caça eficiente viria com o tempo. A anatomia moderna não corresponde ao comportamento moderno. As pistas deixadas pelos utensílios sugerem o lento desenvolver do comportamento criativo. Podemos então supor que a pressão da alimentação foi mais efetiva do que a própria alimentação. A aquisição de novos hábitos gerou os rudimentos da organização cultural. A mudança do ciclo de vida, com o 
prolongamento da infância e a longevidade, uniu pequenos e anciões. Ora, com uma alimentação mais calórica, que por obvio diminui a demanda de alimentação constante, criouse o tempo necessário para a transmissão da experiência. Quando a fala se organizou num código, ocorreria o improvável. A mudança mais impactante, que inclusive mudaria a ecologia do planeta, viria com o Grande Salto Para Frente.

Vejamos ainda mais outro ponto. Como poderiam os machos sair tranquilamente em excursão de caça deixando as fêmeas acessíveis às aventuras de outros machos, inclusive os púberes do próprio bando, e com oportunidades de realizar seus próprios interesses sexuais, mesmo que fortuitos? A sexualidade realmente é um problema, pois a troca sexual pode desorganizar o clã! Uma função psíquica deveria incidir sobre o olfato, para apagar o cio, libertando-nos dos instintos, e sobre a sexualidade, lançando-nos à pulsão, ao inconsciente e à cultura. A cultura modifica a carne. A atrofia do olfato está na base do recalque orgânico. Paralelamente, a ocultação do período fértil das fêmeas deixava-as constantemente disponíveis para o sexo, introduzindo a vontade e o desejo como determinantes no lugar do cio. O abandono da ciclacidade (olfato-cio-instinto) para a constância (visão-desejo-pulsão) do estímulo sexual demandaria, necessariamente, um inibidor eficiente e universal da sexualidade (recalque).

Temos uma confusão para resolver. As características sexuais são produto da evolução de antepassados arbóreos e comedores de frutas. Sofreram modificações a partir do incremento dos hábitos carnívoros, dadas às mudanças impostas pela vida de caçador de campo aberto. A interação destes dois fatores levou ao desenvolvimento de uma estrutura social complexa e organizada para garantir o sucesso da sobrevivência da espécie. Morris (2004) destaca que a primeira transformação foi lenta e teve sucesso relativo. Já a segunda foi rápida, desarmônica, e ditada mais pelas proibições impostas e pela inteligência do que pela mudança genética e instintiva/comportamental. O autor chega mesmo a afirmar que "[...] o comportamento sexual moderno foi menos influenciado pelo progresso da civilização do que esta foi influenciada pelo comportamento sexual” (MORRIS, 2004, p.55-56).

Lembram-se da neotenia? Pois bem, sexualidade e infantilismo são chaves muito caras nesta etapa. Seja nas tolices dos namorados ou na fala infantilóide dos adultos com os bebês, mais do que o sentido do que se diz, o efeito sobre o outro se dá pelo tom e ritmo da voz. É a lalação infantil e erótica que coloca o biológico na cultura, tirando algo do instinto e 
inaugurando a pulsão. As vicissitudes do trilhamento pulsional serão objeto do próximo capítulo.

Com o prolongamento da receptividade da fêmea para além do período fértil, saímos do sexual para o sensual. Assim, podemos propor que a entrada na cultura foi pressionada, de um lado, pela evolução e pela adoção de hábitos carnívoros e, por outro lado, pela mulher.

Como legado primata, dentre outros, preservamos a primazia da visão. Por óbvio enviar sinais visuais seria uma boa forma de distinção. Junto com a adoção da postura ereta, foram-se os pelos. O homem estreava como um macaco pelado. Observamos que os homens são mais infantis em seu comportamento, ou seja, preservam mais comportamentos infantis. Já as mulheres apresentam mais características infantis na sua anatomia (MORRIS, 2005, p. 13), sendo então o corpo da mulher mais moderno, avançado, em termos evolutivos. O corpo da mulher acentua os traços evolutivos da anatomia, mostrando, deixando-se ver, os impactos da neotenia. Características tais como menos pelos, olhos maiores, formas mais arredondadas, bocas, seios, cabelos e tudo que lhe é fenótipo pressionaram para a ação da cultura sobre o corpo. Vale a observação que a cultura, nas técnicas de embelezamento, busca justamente ressaltar tais traços (ver, ser visto, deixar-se ver).

A posição ereta afasta o olfato dos órgãos sexuais, mas os colocam expostos de modo a proporcionar perene estimulação visual. A inexistência do cio e a decorrente constante disponibilidade sexual, acrescidas da posição ereta, estabelecem uma circulação que mostra e oculta o sexual. Vejamos o problema. O homem tinha que caçar para sobreviver. Supriu a inferioridade física com comunicação e próteses (armas). A infância foi prolongada, demandando mais das mulheres, pois estas cuidavam da prole. Os homens tinham que sair, mas sair virou um problema, pois as mulheres estão disponíveis sexualmente para investir e serem investidas. Deixá-las seria imprudente.

Sexo virou um problema que facilmente desagregaria o bando e colocaria em risco a sobrevivência da espécie. Ora, o problema pode virar ele mesmo a solução! Soma-se visão especialista em detalhes, poucos pelos (os detalhes ficam mais visíveis), forte interesse nos outros membros do grupo, muitos músculos faciais com grande possibilidade de expressão, ampla capacidade de vocalização e necessidade de preservação do parceiro. A evolução cuidou de melhorar o sexo, aumentando-lhe a capacidade de recompensa. O orgasmo 
feminino é um privilégio da fêmea humana dentre as outras espécies de mamíferos. O sexo deixa de ser somente um avanço evolutivo que exponencia a variedade genética das espécies que se reproduzem por esta via. No humano, o sexo vai além da reprodução, alcançando a construção da ligação entre os pares para conservar o grupo. Ao inibir o sexo, deixando-o disciplinado segundo as leis que organizam o grupo, vinculando os indivíduos com recompensas mútuas no ato sexual, inventamos o amor e a traição. O recalque deve atingir o sexo para poder liberar o acesso ao sensual.

A postura ereta e a primazia da visão sobre os outros sentidos modificaram o corpo e os encontros sociais. Com a modificação do polegar dos pés, a postura ereta liberou as mãos. Essas ganharam em precisão e sensibilidade, perderam em força. O toque, os estímulos táteis ficaram mais importantes na medida em que perdemos os pelos. Excitados pelo toque e constantemente estimulados pela visão, o corpo cuidou de levantar propagandas sexuais. Zonas erógenas que mandam mensagens sexuais o tempo todo. $\mathrm{O}$ aumento da esclera, parte branca dos olhos, dá ao outro a percepção do que está na mira dos olhos, olhos sempre molhados; a boca, única entre os mamíferos a ser virada para fora, com cor e textura diferente da pele circundante, aumenta a vermelhidão quando excitada; os seios maiores e mais redondos, que atendem muito mais aos olhos do parceiro do que a função fisiológica da amamentação; o pênis desproporcional se compararmos com os outros primatas; o estreitamento da cintura e aumento das nádegas nas mulheres; constituem fortíssimos atrativos visuais para estimulação sexual. Em tempo, destacamos que a cultura reforça e destaca estes sinais, mandando mensagens sexuais visuais o tempo todo. Próteses como batons, sutiãs, e muitos outros artifícios foram desenvolvidos para destacar as mensagens. Mesmo o decréscimo da função olfativa ganhou uma importante cobertura cultural. Cuidamos da desodorização do corpo, mas também mandamos recados ambíguos e estimulantes pelos perfumes. "Sabão, o símbolo da Cultura!” (PALAHNIUK, 2002).

Constituímo-nos enquanto homens lidando com vários estímulos, pressões contraditórias e constantes. Para filtrá-los, e diminuir a pressão, foi necessário o desenvolvimento de um aparelho psíquico, não só mental, na tentativa de viabilizar a sobrevivência. A pressão no aparelho psíquico é proveniente de fontes externas e internas de estímulos. 
Somos uma espécie altamente sexual que, contraditoriamente, procura viver acasalada. Mantemo-nos possessivos com o parceiro e inclinados a mandar sinais sexuais para os outros indivíduos. Primatas por origem, modificamos o corpo e hábitos devido à adoção do comportamento carnívoro. Por fim, construímos uma cultura para regular hábitos e costumes. Esta regulação impôs inibições fortes no sexo, abrindo caminho, a partir do recalque, para o inconsciente e a sexualidade.

\subsection{Ciclo vital}

O cérebro grande e a postura ereta foram requisitos fundamentais para a linguagem, mas, como nos alerta Diamond (2010, p. 69), insuficientes. A longevidade, o tamanho dos testículos e a menopausa também tiveram expressiva parcela de contribuição. Analisemos estes pontos à luz do ciclo vital.

Nosso ciclo vital é bastante peculiar para um mamífero descendente dos primatas. Para que fique claro, temos por ciclo vital tamanho da prole por nascimento, cuidados parentais dispensados à prole, interações entre indivíduos adultos, como os indivíduos selecionam parceiros sexuais, com que frequência acasalam e a expectativa de vida.

Como fisicamente fomos desenhados para emitir estímulo sexual o tempo todo, consequentemente nossa mente ficou fortemente seletiva nesta direção (MILLER, 2000). O desenvolvimento de próteses ganhou o peso de fenótipos estendidos. Sendo partes destacáveis de nós, do nosso corpo (DAWKINS, 1999), levaria naturalmente à erotização destes objetos culturais (aqui incluímos também os hábitos e habilidades) como atratores e estímulos eróticos. É o passo dado no sentido de uma seleção sexual (DARWIN, 2004). Desenvolvemos então uma intervenção cultural nos corpos para mostrar e velar tais estímulos.

Roupas e costumes marcam a proibição do sexo ou do contato sexual na rotina vulgar dos aglomerados humanos. A modificação dos caracteres sexuais secundários emite mensagens ambíguas, possibilitando a provisória suspensão do estímulo. A desodorização é fortemente estimulada. Velamos os estímulos visuais, mas acabamos por abrir um espaço para 
imaginarmos. Começa uma divisão onde o sexo cai para fora da consciência e das interações, mas não de todo... É vital satisfazer o sexual pelos desvios, pervertendo desde a origem sua finalidade.

Quanto mais crescem os aglomerados humanos, mais aumenta a exposição social. Um primata fortemente sexual vê-se agora obrigado a inibir-se como estratégia de evolução cultural. Por mais que se esmere, ficará um resto a pagar. Por quê? Não seria mais fácil evoluirmos no sentido de ficarmos menos sensíveis aos estímulos sexuais? É verdadeiro que nossa elevada sexualidade demanda constante expressão e vazão (MORRIS, 2004, p. 95). Igualmente verdadeira é a necessidade de reprimir culturalmente esta inclinação, inclusive criar mecanismos psíquicos eficientes como o recalque para sustentar a lei de proibição. Mas, se isso não extinguiu é porque continua contribuindo para a evolução, a despeito do trabalho psíquico e social que exige.

Pensemos as vantagens. Um ambiente complexo e estimulante, que demanda muito trabalho, inclusive psíquico, gera muita pressão e sentimento antagônico entre os membros da comunidade. Nossa herança de primata nos deixou fortemente ligados nos outros. Continuamos observando as interações e nos situando segundo as redes de relações. Naturalmente sentimentos antagônicos e ambivalentes florescem entre os membros do grupo social, mesmo na célula familiar.

Se um dos fins da sexualidade é manter o par unido, é necessário que surja medidas para desencorajar o sexo quando o par está separado. O intuito mais óbvio é evitar que terceiros indivíduos se entusiasmem com um elemento acasalado. Em outras espécies em que há acasalamento, mas sem vida comunitária, isso se obtém em grande parte através de gestos agressivos. Mas em uma espécie cooperativa como a nossa é mais produtivo o desenvolvimento de métodos menos beligerantes. A comunicação verbal e as leis simbólicas jogam aqui seu grande papel, como acontece em tantos outros aspectos do contato social (MORRIS, 2004, p. 90).

Observemos nossa linhagem geneticamente mais próxima. Os chimpanzés são altamente agressivos e territorialistas. Constantemente patrulham seu território e executam indivíduos desgarrados não pertencentes ao clã. Quando subjugam outro grupo, frequentemente exterminam os machos e sequestram as fêmeas. Há grande tensão no grupo e 
as relações sociais são fortemente observadas. Ocorrem trocas de alianças e submissão para manejar e diminuir a agressividade e tensão social. Os bonobos são bem menos agressivos. Também são territorialistas, mas não patrulham o território. Observam igualmente os membros dos clãs, fazem alianças e adotam comportamento submisso para minorar as tensões. Contudo, o comportamento agressivo foi substituído pelo aumento do comportamento sexual. A cópula é o meio de mediar a tensão do grupo. Nós, humanos, herdamos ambas as características: somos altamente atentos ao comportamento do grupo, sofremos forte tensão social, estabelecemos relações de força, submissão e interesse, somos territorialistas, muito agressivos e com forte inclinação sexual.

Os primatas desenvolveram uma habilidade social interessante. É um artifício de situação chamado de remotivação. Consiste em mandar sinais sexuais, sem a efetiva disponibilidade para a cópula, para diminuir ou neutralizar comportamentos agressivos ou dominantes de outro membro do bando. Neste surgem modificações da agressividade a partir da excitação sexual, mesmo que discreta.

Ora, embora perigosa, a estratégia é boa! Emitimos sinais sexuais, ou seja, sexualizamos para remotivar comportamentos. Claro que isso gera ambiguidade e demanda trabalho psíquico. Sem muito esforço, observamos como esta estratégia foi determinante com o prolongamento da infância, a referida neotenia. Erotizar o bebê, incrementar cuidados, erotizar os cuidadores foram mecanismos determinantes na construção do psiquismo e das sociedades. Então, mais do que disruptiva, a utilização de comportamentos sexuais em situações não sexuais é uma poderosa força de harmonização e organização do grupo, mas acarreta em custo para o indivíduo.

Conforme argumentamos, a evolução selecionou um amplo conjunto de atrativos sexuais que poderia, na medida em que os grupos humanos aumentavam, levar à comunização do sexo. Mesmo preservando uma anatomia primitiva, contudo, o homem moderno desenvolveu incontáveis formas de inibidores, como regras e costumes. Estes, embora secundários, foram e são vitais para a sobrevivência. O pacto edípico completa a estrutura da jornada evolutiva do homem.

No próximo capítulo veremos como o recalque e a divisão da consciência foram os produtos da operação acima descrita. O alto custo é o constante trabalho psíquico. 


\section{NOS TRILHOS DA PULSÃO}

Freud sempre entendeu o psiquismo humano como um fenômeno decorrente da evolução das espécies, como um "produto" da atividade da interação do sistema nervoso com o meio ambiente em suas dimensões físicas e históricoculturais. Seu conceito de "séries complementares", frequentemente esquecido, é fundamental para quem estuda e se dedica à psicanálise, pois, não existe psicanálise sem a presença do biológico, do filogenético, da fisiologia, da ontologia e da cultura. A ontogênese psicanalítica se, por um lado, não existe sem a história das relações pessoais do sujeito, por outro, está profundamente enraizada no conceito de pulsão que, por sua vez, tem como fundamento as tendências corporais herdadas e adquiridas.

Claudio Rossi

Este capítulo é dedicado à pulsão em Freud. Iniciaremos pela exploração das pesquisas neurológicas do médico Freud, para depois demonstrarmos o circuito pulsional do Freud psicanalista.

Não pretendemos aproximar ou domesticar a psicanálise à luz das neurociências (do passado ou atuais). Isso seria um tanto descabido e, sem dúvida, flertaria com problemas epistemológicos e desvios por demais sinuosos para a boa prática da psicanálise (QUINET, 2009). Esta visita justifica-se por ser a neurologia o berço intelectual de Freud e por neste berço já estarem presentes embriões dos principais conceitos psicanalíticos. Por exemplo, o modelo das afasias que, mesmo sendo consagrado como uma teoria freudiana prépsicanalítica, possibilitou desenvolver e distinguir da neuropsicologia médica uma metapsicologia psicanalítica.

Como veremos adiante, nestes textos pré-analíticos já estão presentes elementos suficientes para falarmos de um modelo psíquico funcionando como um aparelho de linguagem (OLIVEIRA, 1999). Ora, não estaríamos precisamente trazendo para a discussão os efeitos que a linguagem imprime na carne do vivente, justamente pelo fato deste vivo ser falante, dotado de um aparelho de linguagem desenhado e modificado por esta mesma linguagem? Este ponto será melhor desenvolvido no Capítulo 3, quando apresentaremos as 
contribuições de Lacan sobre o aparelho psíquico, a constituição do sujeito e do inconsciente estruturado como uma linguagem.

Tomaremos por ponto de partida neste momento os desenhos e diagramas das pesquisas de Freud sobre os sistemas nervosos dos invertebrados e vertebrados, bem como os modelos e diagramas funcionais da palavra e memória.

\subsection{Células, núcleos e gânglios}

Freud fora treinado pelo professor Ernst Brücke, membro da escola de fisiologia e neurologia de Hermann Von Helmholtz. O ambiente intelectual da época florescia e novas descobertas impactavam o campo da pesquisa médica. A filosofia iluminista de Immanuel Kant já era pungente no pensamento alemão. Louis Pasteur revolucionava a medicina com a teoria dos germes e com a observação dos micróbios. Charles Darwin apresentava sua revolucionária teoria sustentada numa enormidade de observações.

O pensamento científico do século XIX avançava sobre a matéria observável com rigor e método. Ver e descrever tornaram-se instrumentos fortemente privilegiados e amplificados pelo avanço dos métodos e técnicas, destacadamente o microscópio. Minuciosos trabalhos demonstraram a profunda unidade das matérias existentes. Várias teorias buscaram um princípio unificador que utilizassem as mesmas leis para compreender o mundo físico e químico. Na biologia, a exploração dos elementos químicos básicos permitiu o estudo dos protogenotas, cuja informação genética rudimentar não está isolada por uma membrana. Com a evolução, aparecem os sistemas enzimáticos da fotossíntese, revelando a necessidade de separação do ambiente interno e externo com organização e funcionamento distintos. Esta organização sofre modificações a partir da sua interação com o meio (adaptação) e consigo mesmo (mutações). O surgimento das grandes células aeróbicas, com mobilidade intracelular e núcleo envolto por uma membrana contendo um genoma diploide, possibilitou a reprodução por mitose. Com isso, é rompida a simetria das populações celulares, inaugurando a divisão sexual. Por simbiose de um grande número de células, desenvolveram-se organismos pluricelulares, onde no interior as células se diferenciam funcional e estruturalmente. Surge 
um novo modo de emparelhamento com o meio: o sistema nervoso, cuja complexidade possibilita os organismos a modificar o meio segundo intenções (BOURGUIGNON, 1990).

Ao emparelhar sinteticamente as descobertas presentes no momento da formação médica de Freud, fica claro o terreno no qual a futura teoria psicanalítica iria desenvolver-se: organismos diferenciados pela organização; continuidade entre as espécies distintas; órgãos e sistemas superando problemas adaptativos com a separação de ambiente interno e externo; traços primitivos ou ancestrais em organismos modernos; restrição do sexo. Junte-se a isso o forte método de observação clínica, o interesse pelos clássicos Shakespeare e Goethe e temos as bases do pensamento do pesquisador Freud!

As pesquisas neurológicas de Freud começaram pelos invertebrados simples. O método era observação por microscópio, detalhada descrição e reprodução por desenhos e esquemas das estruturas observadas. Na medida em que avançava, o pesquisador percebeu que a organização celular das formas simples são precursores de estruturas mais organizadas e complexas das formas superiores. Ou seja, a organização das estruturas gerava mais diferença do que a morfologia propriamente dita. O interesse pela continuidade entre as espécies e pela complexa capacidade de organização diferenciada deixava cada vez mais enraizada a influência do método de pesquisa sobre Freud (BRIVTO, 1992). Futuramente, o microscópio seria abandonado, mas o rigor do método de pesquisa seria levado à clínica. Os estudos com Charcot aguçaram Freud para o aspecto funcional dos distúrbios psíquicos, pois naqueles pacientes inexistiam lesões anatômicas, embora fossem observáveis os transtornos. A cura pela fala, método em desenvolvimento, apontava fortemente na direção de uma função psíquica operada pela linguagem.

Freud pesquisou de testículos de enguias a feixes cerebrais. Pôde perceber, em estruturas primitivas organizadas, indefinições quanto ao sexo. Nesta época, já produzira trabalhos sobre a bissexualidade de espécies primitivas, localizando na base anatômica seus argumentos. O ponto mais alto de sua pesquisa neurológica veio nas descrições e inferências extraídas da neuroanatomia funcional. Neste ponto, Freud começa a distanciar-se de seu professor Theodor Meyner. Para este, o corpo seria projetado no córtex, aquele propunha que o corpo se representava no córtex. Objetivamente, para Freud "a relação entre corpo e córtex não é topológica, porém funcional" (GAMWELL \& SOLMS, 2008, p. 105). 
Aqui começa uma ruptura interessante. A descrição e o desenho das estruturas podem ser feitos por observações. Contudo, suas funções só são alcançadas por deduções. Ora, isso não as torna irreais! Os processos começaram a chamar mais a atenção de Freud do que a anatomia. Naturalmente, a linguagem, função psicológica complexa, captura a dedicação do pesquisador. Como observam Gamwell \& Solms (2008, p. 32), os desenhos e diagramas de Freud ficam cada vez mais abstratos, distanciando-se de um modelo neuropsicológico, para desenhos mais abstratos, voltados para as funções do cérebro. Vemos aqui uma transição para o modelo metapsicológico, apartado das teorias neurológicas localizacionistas prevalentes à época.

A exploração das estruturas físicas rendeu a possibilidade de generalizar o princípio. Ora, se estruturas primitivas podem existir em organismos modernos, o mesmo pode ser aplicado a funções. O primitivo e o infantil ganham privilégio na construção do modelo freudiano da mente. Posteriormente, a lógica do modelo de aparelho ou máquina seria utilizada para alcançar as afasias.

No artigo A Interpretação das Afasias, Freud desenvolve a tese contrária ao modelo localizacionista das afasias. Pensa-as como perturbações do aparelho de linguagem (OLIVEIRA, 1999, p. 07). É importante observarmos que, neste texto considerado prépsicanalítico, Freud rompe com o campo neurológico e desenha o embrião de um modelo sustentado na representação. Toma a palavra como a unidade funcional da linguagem, e a descreve como uma complexa montagem de representações. 
Vejamos o esquema psicológico da representação da palavra (modificado de $A$ Interpretação das Afasias, FREUD, 1977, p. 46, fig. 3)

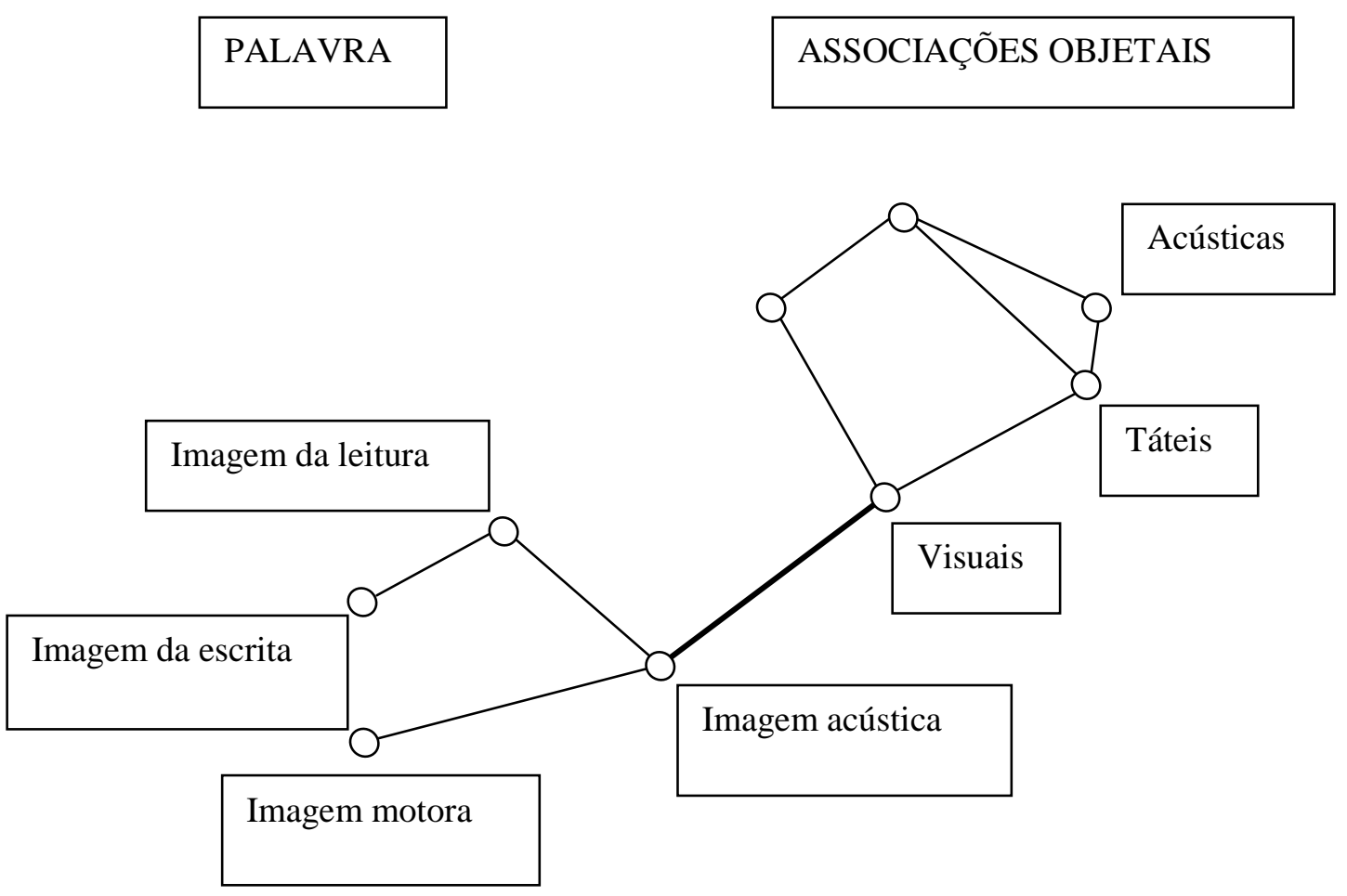

Gamwell \& Solms (2008, p. 109) observam que a representação de palavra dá-se como um sistema fechado, enquanto a de objeto como um sistema aberto. A ligação entre representação de palavra e representação de objeto dá-se apenas pela imagem acústica, ou seja, pela representação do som (palavra, significante).

Segundo este modelo, a significação da palavra ocorre devido à ligação entre a imagem acústica da representação da palavra e a imagem visual da representação de objeto. Temos então um esquema psicológico da representação da palavra, cuja imagem acústica representa a palavra e a imagem visual do objeto ocupa o lugar das associações de objetos. Como destaca Oliveira (1999, p. 19), Freud aponta para a ruptura da relação palavra-objeto. Consequentemente, no processo de significação da palavra o referente fica de fato excluído, pois não faz parte dos termos da operação, enfraquecendo a tese de que a ruptura seria apenas a resultante de palavras com funções somente gramaticais. A importância determinante da 
criação de um aparelho de linguagem, para ser o determinante do Salto, começa a ganhar musculatura.

A origem auditiva da linguagem conferia a ela, segundo Freud (1977), a característica de concretude, justamente por ser perceptual. Isso possibilitou dizer que as neuroses seriam distúrbios funcionais do sistema nervoso. Não o sistema neuroanatômico, mas o sistema de linguagem, cuja realidade psíquica é concreta. As estruturas neurológicas já não são o objeto de Freud. Seus desenhos e diagramas, embora busquem nomeações de funções neurológicas, são esquemas de representação cada vez mais abstratos de um aparelho psíquico constituído, modificado e operado pela linguagem. Esta assume características concretas e marca a carne do vivente justamente por ele ser falante.

\subsection{Entre o psíquico e o somático}

O termo pulsão não é comum ao português, fica geralmente restrito ao jargão psicanalítico. Contudo, origina-se do alemão comum. Por ter sido elevado ao estatuto de conceito, teve seu campo semântico expandido, o que leva a necessidade de entender um pouco mais as origens do termo. Portanto, farei uma pequena incursão terminológica, sem perder de vista que o objetivo central é a demonstração do conceito, não uma exegese do mesmo.

Hanns (1996) destaca em seu dicionário que o verbo treiben e o substantivo trieb articulam quatro momentos, indo do geral ao singular. Tem um sentido mais amplo, com a manifestação no corpo somático do ser vivo; e mais restrito, com manifestação para o ser. O sentido é sempre o da força que coloca em ação os seres de cada espécie. O significado é de ímpeto perene, tendência, inclinação, força inata de origem biológica dirigida a certas finalidades, impulso que toma o ser, vontade intensa, broto ou força que faz brotar. O destaque nos termos dos significados é em razão da aplicação conceitual que veremos adiante, pois a elegância e a leveza dos textos freudianos residem, em muito, da habilidade de extrair do vocabulário comum o peso dos conceitos. 
Destacando o sentido contido no termo, já avançamos na compreensão conceitual. As conotações de trieb circulam sempre em torno da ideia de força poderosa e irresistível que impele. Não é algo que brota a partir do sujeito, mas faz com que o movimento brote no sujeito. Aparece na qualidade de base não-volitiva e categórica, podendo posteriormente revelar-se como um instinto ou uma vontade. Assim, o termo é mais afeito à base. Não é desde o início desagradável, assume esta forma caso não satisfeito. Fatalmente chegará ao desagradável, pois trieb gera estímulo constantemente. Não é a ação, e sim o que leva à ação, logo se revela em dois tempos: um, fonte externa que afeta o sujeito; dois, o efeito deste contato com o íntimo do sujeito (HANNS, 1996, p. 338-340,). Repare que o alcance descritivo do termo trieb é pobre, sua potência está em revelar o aspecto inapreensível da força que impele ao movimento.

O circuito pulsional corre sempre do genérico para o específico. Inicia-se a partir de uma fonte pulsional, gera estímulo pulsional, até a estase/acúmulo ${ }^{2}$ atingir níveis necessários de pressão. Neste ponto temos uma dupla destinação possível antes de gerar descarga e satisfação: arco reflexo, reações somáticas ou ideia/representação mais afetos (HANNS, 1999).

Freud afirma que a pulsão é o conceito limite entre o psíquico e o somático (FREUD, 1912). Assim, a pulsão teria sua fonte no corpo, mais precisamente nos órgãos do corpo e não no corpo organizado do organismo; e seria um estímulo para o psíquico, não um estímulo psíquico. Deste modo, não é possível ou aceitável tomarmos os representantes da pulsão (triebrepräsentanz), ou ainda, os representantes psíquicos (psychische repräsentanz) pela própria pulsão (trieb). A pulsão está fora do aparelho psíquico, seus representantes dentro. Podemos sem muito esforço atribuir parte da confusão conceitual que atingiu certas práticas psicanalíticas modernas às escolhas do tradutor. Traduttori, Traditori! As escolhas de tradução são justificadas por quem as faz e estão em constante revisão face às controvérsias que geram.

\footnotetext{
${ }^{2}$ A opção de tradução adotada pelo autor Hanns (1999) para o termo freudiano stauung, acrescenta o vocábulo estase ao vocábulo acúmulo, tradução estabelecida pela Edição Standard Brasileira das Obras Psicológicas Completas de Sigmund Freud (Editora Imago, Rio de Janeiro, Brasil, 1980), criando estase/acúmulo. Este acréscimo importa à compreensão da intenção freudiana, entre outros sentidos: 1) incapacidade de agir; estado de impotência; 2) tensão emocional persistente por longo tempo, cuja resolução é dificultada, gerando sentimentos de prazer intenso e, às vezes, por pretextos banais, violenta descarga emocional (Dicionário Houaiss da Língua Portuguesa; Editora Objetiva, Rio de Janeiro, Brasil, 2001).
} 
Como a pulsão é força que vem de fora do aparelho psíquico, estimula e compele à ação, vamos ao Projeto (FREUD, 1895) para resolver o problema da distinção do que é estímulo interno e externo. O sistema de neurônios $\psi$ é estimulado a partir de duas fontes. Uma exógena, que chega através do sistema dos neurônios $\varphi$, e uma endógena que afeta diretamente ao núcleo do sistema $\psi$. Estes estímulos produzem Qs, quantidades de energia, que excitam os neurônios. É da natureza do neurônio oferecer resistência à excitação, demandando quantidade de energia para romper o limiar de repouso e passar o estímulo para frente. Ao separar as fontes de excitação em endógenas e exógenas, Freud chega à conclusão que as fontes afetam diferentemente o sistema $\psi$. As excitações provenientes do mundo externo não atingem diretamente o sistema $\psi$, perdem força ao transitar pelo sistema $\varphi$, que contém os órgãos dos sentidos. Os estímulos endógenos não contam com um sistema de filtro entre os órgãos e o sistema $\psi$, deixando este desprotegido contra a excitação causada pelas Qs oriundas do interior do corpo. Justamente por isso, é possível ver nessa Q de afetação direta a matriz pulsional no aparelho psíquico. Estes estímulos provenientes do corpo chegam ao psíquico para, a partir daí, serem trabalhados. Entenda-se bem, trabalho psíquico é diminuir a excitação do aparelho psíquico.

Ora, o que ocorre quando o aparelho não consegue embarreirar, resistir, às excitações? Freud nos diz que, caso o aparelho não consiga capturar, transformar e ordenar as excitações endógenas, mas estrangeiras ao sistema $\psi$, há a liberação de sensações desagradáveis e/ou patogênicas (FREUD, 1895). É interessante notar que são designadas patogênicas, não patológicas. As primeiras referem-se às origens dos núcleos patológicos, podendo ou não haver manifestação patológica propriamente dita. Já as últimas são tipos de organização psíquica cuja manifestação é a falha do aparelho psíquico em evitar as intensidades da ação pulsional no próprio aparelho. É muito estimulante observar que este modelo proposto por Freud supera a divisão normal/patológico, abrindo uma nova perspectiva para o estudo da psicopatologia do século XIX.

Conseguimos tirar algumas consequências do modelo apresentado no projeto. Primeiro, a pulsão gera estímulo para o psíquico, lançando-o ao trabalho. Afirmamos com Freud que a pulsão produz estímulo, mas não pode ser identificada a este. Por ser externa ao psíquico, embora interna ao organismo, é razoável afirmar que a pulsão não é regida pelos mesmos princípios do aparelho psíquico. Passa a sê-lo quando é capturada pelo aparelho psíquico na forma de triebrepräsentanz. Quando o aparelho destina-se a reduzir o desconforto 
da excitação, Freud coloca-o sob o registro de princípio do prazer. Neste terreno estão, tão somente, os representantes da pulsão nas formas de representação (vorstellung) e afeto (affekt), o que já denuncia uma organização psíquica. A pulsão propriamente dita está situada além do princípio do prazer, desorganizada e anárquica.

Freud destaca como características essenciais da pulsão a origem no corpo e a força de estimulação constante. O corpo nunca esteve fora das preocupações da psicanálise. Mas que corpo? $\mathrm{O}$ ensino freudiano teve sua marca inaugural a partir dos estudos sobre a histeria e sobre os sonhos. Com isso, a construção teórica de Freud esforça-se para distinguir corpo e organismo. O corpo assume lugar distinto do alvo das intervenções médicas. Antes, é palco do complexo jogo de relações entre o psíquico e o somático. Nesta dupla inscrição assenta-se o conceito de pulsão, conceito limite, cuja origem fora atribuída à excitação de órgão. No corpo aparecem a origem da pulsão, na figura da excitação de órgão, e sua finalidade (FREUD, 1905). É no corpo libidinal, revestido pelos significantes, que atua a psicanálise (FERNANDES, 2003). Então o corpo acumula tanto funções orgânicas, quanto desejos inconscientes (representantes da pulsão), como é fonte da pulsão que pressiona o aparelho psíquico.

\subsection{Um recalque para haver um circuito}

Voltemos então ao circuito pulsional. Este se inicia a partir de uma fonte pulsional (Triebquelle), gera estímulo pulsional (Triebriez), até o estase/acúmulo (Stauung) atingir níveis necessários de pressão (Drang). Neste ponto temos uma dupla destinação possível para os fins de descarga (Abfuhr) e, consequentemente, satisfação (Befriedigung). São elas: arco reflexo, reações somáticas ou ideia/representação (Vorstellung) mais afetos (Affkte). O circuito pulsional corre sempre do genérico para o específico. 
Em seu livro intitulado A teoria pulsional na clínica de Freud (1999), Hanns esquematiza de maneira muito clara e feliz a teoria do circuito pulsional de Freud através do seguinte gráfico:

\section{Trilha mento Pulsional proposto por Freud}

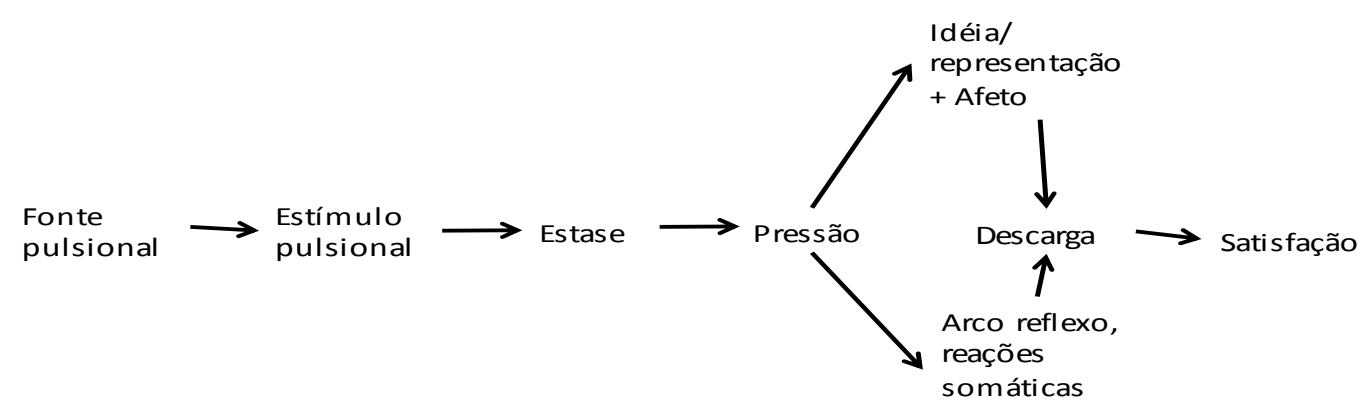

(Hanns, 1999)

Vejamos a clínica. A histeria apresenta de maneira muito contundente que as dores, paralisias, tosses e toda sorte de incidências sobre o corpo não são a realidade biológica do organismo, ou seja, não são expressões diretas do corpo doente, com sua fina e complexa interação entre os sistemas imunológico, nervoso e endócrino; e sim material de uma narração, ato de linguagem que testemunha o sofrimento ora expresso no corpo. Extraímos já uma importante consequência: o corpo não sofre só do que vai mal nos órgãos. Pode sofrer de algo que tem sua origem no psíquico. O conflito psíquico sofre ação do recalcamento e, deste modo, uma significação inconsciente pode recair no sistema corporal, nas representações pulsionais que constituem o corpo libidinal.

A noção de recalque primário é estruturante/fundador do sujeito, sendo a repressão um mecanismo de defesa secundário. O conceito de recalque primário, original, eleva-o ao nível de elemento constitutivo do inconsciente (JORGE, 2008, p. 23). A ocorrência do recalque e da repressão já denuncia a operação em dois níveis de sistema psíquico. $\mathrm{Na}$ 
passagem de um elemento qualquer de um sistema para o outro, esse elemento sofre transformações ao modo da refração da luz (LACAN, 1985).

Este pequeno desvio sobre o conceito de recalque e seus derivados busca ampliar o debate do por que a sexualidade ser alvo privilegiado do recalque. Pulsão e recalque se relacionam dado o fato da pulsão ser um estímulo endógeno, cujo afastamento possui eficiência limitada. A necessidade conceitual do recalque originário, e da decorrente clivagem do aparelho psíquico como fundadora do inconsciente, vem do modelo funcional do aparelho que, ao solicitar o recalque secundário, necessita logicamente que a divisão entre consciente e inconsciente, na qualidade de lugar, já esteja feita. Portanto, a satisfação pulsional, mesmo que parcial, causaria prazer ao diminuir a tensão. Contudo, a satisfação em um sistema pode proporcionar desconforto no outro, pois os sistemas possuem níveis distintos de organização.

O recalque incide direto sobre o sexual, pois o sexo é o trauma (ruptura, descontinuidade do aparelho psíquico). A bissexualidade foi objeto de longas e produtivas discussões entre Freud e Fliess. As delirantes teorias deste último encontraram em Freud um terreno fértil. Os estudos sobre as gônadas sexuais das enguias já haviam despertado o interesse de Freud para o tema da bissexualidade. As pesquisas neurológicas o haviam alertado para o fato de estruturas primitivas estarem presentes em seres evoluídos. Os traços primitivos, infantis, são restos da memória evolutiva.

As discussões com Fliess desenharam a possibilidade de elaboração da perda do objeto do desejo sobre a sexualidade humana, e da análise de seus representantes pelos caminhos associativos deixados pelos traços de memória.

O desejo marcado e constituído por esta falta irreparável possibilitou o advento do simbólico, uma novidade evolutiva que, embora biologicamente a espécie estivesse pronta, arrancou tardiamente os hominídeos das leis naturais, lançando-os para a cultura com suas leis simbólicas. A sorte de problemas que este ex-macaco doravante iria enfrentar seria de outra ordem!

As indicações freudianas sobre a posição ereta e sobre a perda da importância do olfato em relação à visão parecem muito promissoras para entendermos o nascimento das pulsões. Contudo, cabe explorar um pouco mais, sem o constrangimento das aventuras especulativas, os precursores destes dois pontos. O privilégio da visão e a postura ereta foram 
desenhados antes da ruptura, e sofreram importantes pressões que contribuíram para o desenho final.

A passagem da primazia do olfato à da visão marcou a passagem do funcionamento instintivo ao funcionamento pulsional. Conforme apresentado no capítulo anterior, podemos dizer, sem exageros, que a possibilidade do humano nascer decorre desta passagem.

Esta passagem desenhou também a grande característica da sexualidade humana. Com a postura ereta veio a exibição dos órgãos sexuais masculinos e a ocultação dos femininos. O pênis e a bolsa escrotal foram expostos à frente, enquanto a vulva ocultou-se. É tentador pensar nas contribuições desta exposição/ocultação na angústia de castração, mas deixaremos isso para outro momento. Com o declínio do olfato, o recalque incidiu sobre toda a sexualidade, obrigando o circuito pulsional às satisfações parciais, aos deslocamentos e às sublimações. Conforme propôs Jorge (2008, p.44), a inauguração do modelo pulsional a partir das modificações impostas pela primazia da visão sobre o olfato leva o sexual a aproximar-se originalmente do escópico. Assim, podemos afirmar que, em sua essência, a pulsão é escópica e desenvolvida a partir de primitivos precursores.

A observação de Jorge (2008) sobre a pouca literatura dedicada ao conceito de recalque orgânico, anterior ao originário, serviu-me de motivador para o Capítulo 1. Lá, busquei privilegiar os precursores do recalque orgânico, justamente por ver neles a possibilidade lógica (ou mitológica) de sustentação. Este terreno, de fato pouco explorado, guarda ampla possibilidade de avanço sobre as teorias das pulsões. É uma pista muito cara sobre os misteriosos apontamentos freudianos sobre o filogenético e sobre a constituição da humanidade enquanto tal. Afinal, ainda é enigmática a resposta do que nos fez acordar para a humanidade.

No Capítulo seguinte desenvolveremos como a linguagem impacta a carne, criando um sujeito do inconsciente. 


\title{
3. FEITO UMA LINGUAGEM
}

\author{
Eu sou você que se vai \\ No sumidouro do espelho \\ Aldir Blanc e Guinga
}

Este Capítulo é dedicado à demonstração dos efeitos da linguagem sobre o ser vivo. Conforme dito nos Capítulos anteriores, o uso de palavras com funções apenas gramaticais demandou uma nova organização psíquica. Esta organização atende a características funcionais, não estando vinculada diretamente à anatomia. $\mathrm{O}$ funcionamento de um aparelho de linguagem, desenvolvido em cima da máquina biologicamente desenhada, arrancou o homem da natureza, criando um Salto jamais visto em outras espécies. Com a perda da ordem natural, instintiva, o homem criou um fantasma dentro da máquina: o inconsciente. A humanidade despertada a partir do Salto seria efeito do inconsciente sobre um corpo biológico desenhado ancestralmente?

\subsection{O fim do indivíduo e a constituição do sujeito}

No período em que dedicava seu ensino ao retorno a Freud, Lacan (1998, p. 96) adverte seus interlocutores que a função do eu não é a do eu da consciência, sendo-lhe, em alguma medida, oposta. Este descentramento da consciência é fundamental para todo o desenvolvimento da psicanálise, do inconsciente como lugar, e de nossa argumentação. A radicalidade da experiência do inconsciente, divisão subjetiva - spalltung (FREUD, 1914 [1938]), leva a noção de indivíduo ao fim. Este eu psicológico ou fenomenológico, entendido como unidade indivisível, é lugar de síntese, de autonomia e de clareza. Lacan sustenta a tese freudiana de que o eu não é dado de saída, não estando desde o princípio constituído no ser humano. Contudo, acrescenta à argumentação freudiana da divisão do eu relevantes aspectos à sua montagem. Sim, a constituição de um eu passa por um complexo sistema de 
acomodações para se constituir como instância, por assim dizer, montada e identificada como $e u$.

No Capítulo 1 vimos que a modificação anatômica necessária para abrigar um cérebro maior diminuiu a prole, e fez o filhote humano nascer antes do pleno desenvolvimento de seu sistema nervoso. Ocorreram mudanças no ciclo vital e no comportamento. A infância ficou prolongada, criando a necessidade de organização diferenciada de cuidados específicos com os neonatos e infantes (MORRIS, 2004). A fala teve uma importância crucial nas relações entre homem, mulher e sua prole, colocando juntos jovens inexperientes com anciões experimentados (DIAMOND, 2010, p. 67). A junção entre gerações com diversidade de experiências e o incremento de novos hábitos alimentares fortaleceu a base ancestral da sociabilidade dos primatas e da cooperação dos carnívoros. A conversação estava nascendo como meio de cultura para o desenvolvimento da nossa espécie.

No Capítulo 2 vimos como a origem auditiva da linguagem conferia a ela a característica de concretude. Justamente por ser perceptual, o sistema de linguagem confere ao falante realidade psíquica concreta. Acrescentamos ao desenvolvido naquele ponto, as observações que Saussure apresenta em seu Curso de linguística geral (1996). O autor afirma que a realidade linguística, por ele chamado de "ponto de vista", precede o objeto, não o contrário. Nesta feita, o autor lança a realidade objetiva a um ponto sempre perdido, não mais alcançado pelo ser falante. Destaca que a imagem verbal não se confunde com o som. Este é concreto, aquela é função psíquica da mesma forma que o conceito a ela associado. Atento aos avanços da linguística, principalmente no que toca a diferença entre a linguagem e língua e da teoria do significante, Lacan traz a noção de inconsciente estruturado como uma linguagem e propõe uma nova maneira de pensar a construção da subjetividade. Como seria?

Utilizando-se da psicologia comparada, Lacan articula o fenômeno de o filhote humano reconhecer-se na imagem refletida no espelho como o logro da unificação do eu adquirida antecipadamente. Essa antecipação é atestada pela frágil definição da anatomia fantástica da histérica ou dos fenômenos de fragmentação do corpo da esquizofrenia. Os processos de formação do $e u$, demonstrados pela experiência psicanalítica, levam a uma reflexão diversa do eu-indivíduo, apontando propriamente para um eu fragmentado, desconhecido e dessemelhante a si próprio (LACAN, 1998, p. 103). 
A imagem do corpo tida e reconhecida em sua forma é, no processo de formação do $e u$, constituinte deste próprio $e u$. A imagem do semelhante oferece a condição necessária para o engodo da unidade. Assim, o filhote do homem, lançando mão de um complexo de identificações àquela imagem, superará a fragmentação dos estímulos que o envolvem. Nestes termos, o eu não é dado de saída, tendo na sua formação o estabelecimento de funções distintas para a imagem, mais prontamente identificada a um eu da consciência (moi), e a um $e u$ desconhecido de si mesmo, morada do inconsciente $(j e)^{3}$. Nesta montagem do $e u$, as suas funções estabelecem-se de modo ambíguo, revelando a existência de um duplo (LACAN, 1998, p. 101).

No animal há uma imagem da espécie, um padrão estabelecido de repertório respondente à gestalt $^{4}$ de sua espécie. Este padrão inato confere o estatuto de instinto às respostas dessa natureza. É válido o argumento que a imagem influencia o comportamento do animal, mutando-o, maturando-o ou mesmo obrigando-o à posição respondente. É assim para o pombo, para o gafanhoto e para uma infinidade de espécies cujo repertório está capturado pela imagem do outro, sem interferência de uma linguagem. Temos um padrão da raça, um instinto (LACAN, 1998, p. 99).

Uma vez que no humano o processo decorre da alienação na própria imagem, para integrar minimamente o corpo despedaçado pelas excitações, falamos de pulsão, não de instinto. Lembremos com Freud que o ego $o^{5}$ é formado a partir da diferenciação dos estímulos endógenos e exógenos. A formação do ego é uma necessidade que surge para atender ao princípio de realidade, diferenciando-o do princípio do prazer. Surge impondo-se como

\footnotetext{
${ }^{3}$ Embora a edição brasileira, tanto dos Escritos quanto de $O$ Seminário, tenha optado por traduzir os termos je e moi por [eu] e eu, respectivamente, preservamos os termos no original em francês para asseverar a divisão subjetiva e facilitar a localização do leitor na argumentação desenvolvida. Assim procedemos por acreditar que muitas vezes a homografia pode ocasionar confusões indesejadas e levar a distorções na compreensão.

${ }^{4}$ Preservamos o termo no original em alemão devido ao fato de estar assim impresso nas referências bibliográficas adotadas e por ser um termo consagrado na psicologia da percepção.

${ }^{5}$ Preservamos o termo ego Por ser a opção adotada pela tradução brasileira dos textos de Freud. A referida tradução consagrou o vocábulo latino ego como tradução do alemão ich, embora o termo latino não tenha sido utilizado pelo próprio Freud. Em extensa nota (LACAN, J. O Seminário - Livro 2 - o eu na teoria de Freud e na técnica da psicanálise, Jorge Zahar Editor, Rio de Janeiro, 1985, p. 408), o tradutor brasileiro de $O$ Seminário de Lacan defende a utilização do vocábulo sem o artifício do latim. Para os efeitos deste trabalho, estabelecemos equivalência entre os vocábulos eu e ego.
} 
barreira, filtro para os referidos estímulos, originado das marcas que estes estímulos deixam no aparelho psíquico que ora começa a constituir-se (FREUD, 1895, p. 376).

A imagem virtual é a base da primeira identificação, possibilidade de um $e u$ advir. A identificação é o mais primitivo laço com o outro. Constitui-se propriamente o modelo de formação do $e u$ quando possibilita a identificação com o objeto e com o modelo que se quer ser. Esta dialética de ser/ter contida na relação com a imagem é dotada de ambivalência (FREUD, 1921, p. 133). Identificada à imagem, a criança supera a inapetência motora, ordenando e integrando os diversos estímulos que a acometem. É correto afirmar que é pela identificação que há a transformação do filhote do homem, preso à condição de completa dependência, em agente da fala. Eis aqui uma das mais importantes ações da modificação do ciclo vital descrito no Capítulo 1. Neste processo de identificação à imagem sedimentam-se as bases da matriz simbólica que a linguagem, em um tempo futuro, dará a este animalzinho a condição de sujeito (je) na linguagem (LACAN, 1998, p. 98). É a operação concreta da linguagem na carne do falante.

A formação do $e u$ está ocorrendo em dois campos, um real e outro virtual. O (moi) constitui-se sobre a imagem do próprio corpo, imagem esta inexistente enquanto ser, posto que é reflexa, inexistindo sem o espelho. O efeito psíquico desta imagem é vital. O júbilo da imagem está justamente na constituição alienante do Um, pois, na tentativa de capturá-la, é-se capturado pela imagem. Esta é a matriz simbólica do eu que possibilitará toda a subjetividade. O eu é formado por identificação; identificação cuja base é antecipada por sua imagem completa. Quem ascende é um $e u$ impostor, pois a ilusão necessária da completude encobre a fragmentação inerente ao ser da fala.

\subsection{Casa dos espelhos}

Lacan (1986) recorre ao esquema óptico para demonstrar a constituição do $e u$ a partir da imagem do semelhante, alargando a compreensão sobre a identificação apresentada por Freud (1905 e 1914) no Complexo de Édipo. Naquele esquema situa a constituição do corpo no campo virtual, derivada da relação com a imagem. O eu é articulado no registro do 
imaginário, onde, na topologia, supera a fragmentação vivenciada pela imagem inteira do outro.

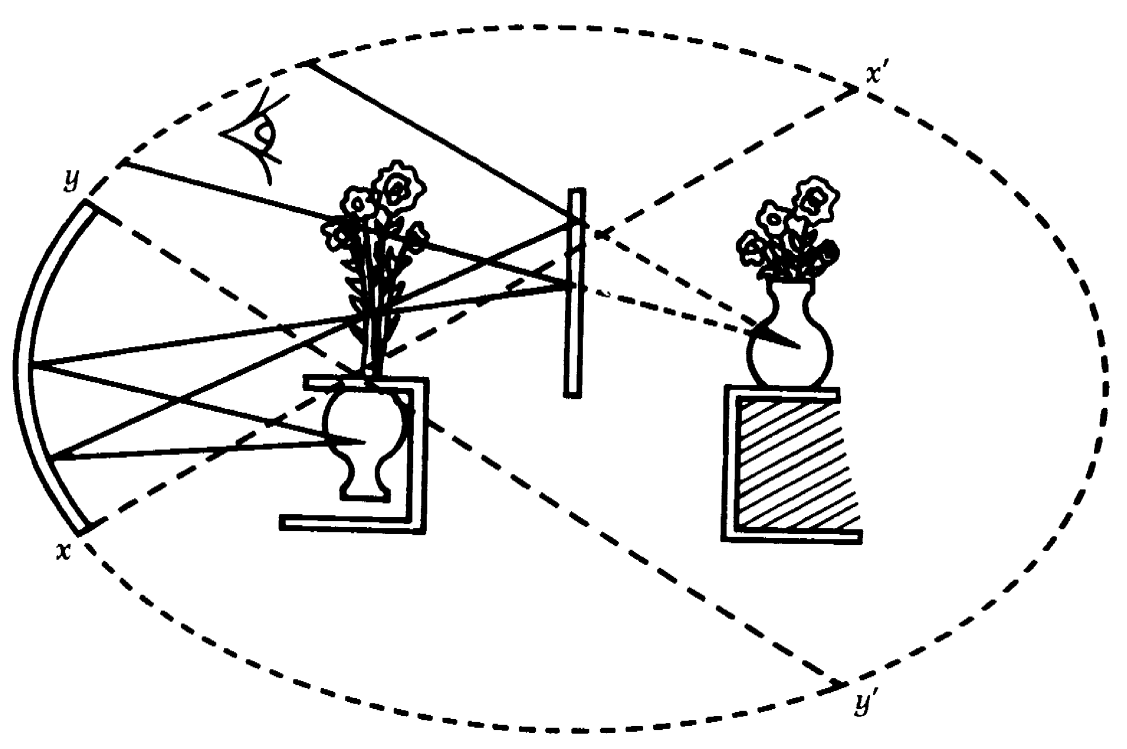

Assim, esse processo conhecido como Estádio do Espelho possui estatuto maior do que um "momento do desenvolvimento humano", como diz Lacan. Todo processo de Urbild do $e u$ é assumido como tal nas relações do sujeito para com sua imagem (LACAN, 1986, p. 91). Uma unidade é adquirida e assumida quando a fragmentação é superada pela alienação na imagem. A superação do despedaçamento do corpo, da fragmentação das pulsões, não seria possível sem o narcisismo. Conforme vimos no Capítulo 2, a possibilidade de a libido investir em objetos e de tomar o próprio $e u$ como objeto é que propicia a acomodação da imagem, função apaziguadora do outro. A imagem do corpo no espelho opera como gatilho da libido que circula do corpo à imagem, da imagem ao eu e ao mundo, produzindo seus efeitos. $\mathrm{O}$ registro assim estabelecido é conhecido como imaginário. A cobertura que a libido pode então fazer sobre os objetos externos e sobre o próprio corpo dá a estes o estatuto de objetos fálicos, que, na sua vertente imaginária, são próteses para a falta. Lembremos que em tempos primitivos, a construção e incorporação das próteses foi um importante precursor para a saída da natureza e para a abertura da humanidade.

\footnotetext{
${ }^{6}$ Optamos por manter o termo no original por ser esta a opção da tradução brasileira do texto de referência.
} 
É importante resgatar aqui o valor das três grandes mudanças que separaram nossos ancestrais dos grandes símios apresentadas no Capítulo 1. A primeira mudança foi a adoção da postura ereta que, ao liberar os membros anteriores, possibilitou a confecção de ferramentas. A segunda mudança seria a divisão de nossa linhagem em duas espécies distintas. Duas espécies vivendo na mesma área devem realizar papeis ecológicos distintos e, normalmente, não se reproduzem entre si. Isso gerou o desenvolvimento de novos hábitos sociais e de comunicação. A terceira foi o uso regular de ferramentas e a transmissão de seu uso e confecção, ou seja, trabalho sistemático (DIAMOND, 2010). As três mudanças destacadas foram possíveis a partir dos efeitos da linguagem sobre o vivo e do desenvolvimento de um aparelho psíquico. A criação e uso de próteses para recobrir as faltas e inabilidades é uma característica marcadamente humana, desenhada a partir do Salto. Eis o cerne da argumentação: o que nos faz humanos é efeito da linguagem sobre a carne, com a possibilidade de a libido investir em objetos, bem como no eu. Por fim, são próteses imaginárias que recobrem a descontinuidade do simbólico para escamotear a falta real.

Contudo, não é sem dificuldades que ocorre essa acomodação do imaginário no homem (LACAN, 1986, p. 164). O horror da experiência de castração é ligado àquilo que se vê, conferindo o desvio da imagem à possibilidade de eludir a falta (CHATELARD, 1995, p. 83). O despedaçamento é vivido de modo intenso, demandando ao outro uma ação específica, como desenvolvido no Capítulo 2. Esta ação não vem só, traz no ato do outro o acesso ao Outro. Perde-se aí um objeto jamais recuperado (LACAN, 1988, p. 71). Lacan (1985, p. 174) chega mesmo a afirmar que "nada de fecundo ocorre para o homem a não ser por intermédio de uma perda do objeto". Destacamos este ponto da argumentação, pois é possível identificarse mesmo com o objeto, reduzindo-se a ele, ou com o eu oferecido pela imagem, saída ortopédica e claudicante, mas que preserva a possibilidade de um (je) advir no circuito estabelecido como (moi) (LACAN, 1980, p.135). 


\subsection{Se eu estou aqui, como estou lá?}

Com Lacan (1985, p. 37), vimos que o eu não é posto desde as origens. É uma função psíquica adquirida pela ação da linguagem no corpo, pois não se trata de uma ontologia, mas dos efeitos da linguagem. Esta tira do vivo o seu ser, ou seja, uma representação plena do vivo na linguagem. Repetimos, é necessário identificar-se em um outro para através dele alienar-se no Outro. Assim, esta articulação parece oferecer sustentação para a tese de que o inconsciente é efeito da linguagem, estruturado como uma linguagem, e que este efeito proporcionou o Salto, ou seja, o rompimento com a MãeNatureza e o florescimento da civilização.

Nestes termos, temos no Estádio do Espelho a operação de dois registros, o imaginário e o simbólico, contornando o despedaçamento que mais tarde será nomeado por Lacan como real. Este, sim, já está nas origens, mesmo sob o signo do instinto de morte ${ }^{7}$, mais tardiamente aparecerá com o nome de gozo, perda indelével assinalada mais acima na referência ao Curso... de Saussure (a linguagem é anterior ao objeto, deixando o real inacessível). É ao real que o aparelho psíquico desenvolve-se em resposta (LACAN, 1998) para conter o horror do despedaçamento (FREUD, 1940 [1922]). A construção de uma unidade corporal ancorada na imagem é testemunho do trabalho psíquico envolvido nesta empreitada. O declínio dos instintos e a assunção das pulsões, com seus representantes pulsionais compondo a gramática inconsciente, lançou a realidade ao real, enterrando-a na marca de algo sempre perdido e inacessível.

O eu identificado a uma unidade fundamenta-se na relação imaginária e decorre do ato psíquico que possibilita a função do narcisismo, ou seja, tomar-se como objeto de investimento libidinal. Ao ser humano não resta outra possibilidade de transpor a fragmentação do $e u$, a não ser pela superação na miragem. A imagem realiza-se fora de si abrindo então dois campos: o do sujeito e do Outro -, sendo-lhe próprio o investimento

\footnotetext{
${ }^{7}$ É importante notar que durante os anos de O Seminário, Lacan preserva o termo instinto. Longe de ser uma imprecisão conceitual das possíveis traduções do trieb freudiano, o termo conota que o instinto de morte tem um objeto específico - a saber, o objeto (a) -, diferentemente dos representantes pulsionais que ao entrarem no aparelho psíquico por meio da representação podem assumir qualquer objeto.
} 
libidinal. Lacan (1986, p.165) chega mesmo a chamar de investimento libidinal aquilo através do que um objeto se torna desejável, introduzindo a função vital do desejo.

O desejo assume posição correlata à falta, sendo essencialmente uma negatividade. Não é propriamente uma função originária, embora seja de visceral importância, uma vez que a identificação à imagem supera a fragmentação do corpo. O desejo então é apreendido primeiramente no outro, decorrendo na alienação do desejo no campo do Outro. O desejo, situado no outro, tem sua apreensão ambivalente e fragmentada pelos objetos localizados neste outro. A distinção obtida do outro ao Outro é de todo confusa, opera deixando suas marcas. Nesses termos é que o sujeito, ao superar sua divisão, sua falta, não sabe mais do seu desejo.

A com/fusão decorre do fato de o desejo ser reconhecido pela ação mediadora da imagem própria e do corpo do outro, sendo por este corpo que se reconhece o desejo. É neste desenvolvimento que o desejo do sujeito funda-se no campo do Outro, sobre as bases do corpo do outro. O desamparo original possibilita que o desejo se aloje no outro, esse detentor de objetos que podem ser investidos de forma fálica.

A imagem oferecida por Fink (1995) em The Lacanian Subject - Between Language and Jouissance é bastante feliz para ilustrar o ponto no qual o Outro (Other) vem fundido no outro (mother) para a criança (child). Para manter o vigor da ideia, é necessário preservar os termos no inglês original.

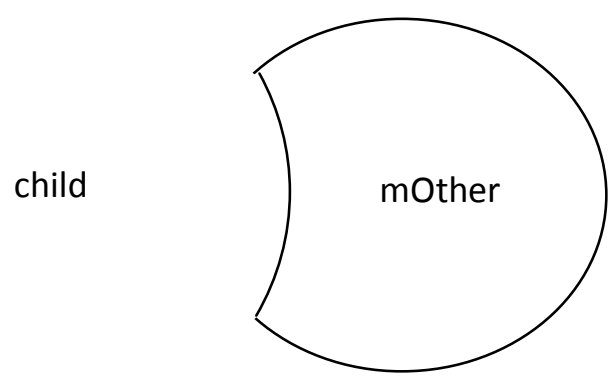


A imagem que interessa aqui não é a do reflexo em sua objetividade, mas os atributos conferidos a esta imagem. Essa proporciona unidade, garantindo em sua feita a corporeidade. Deste modo, a imagem articula os lugares que a maturação do corpo deixa vacante. O reconhecimento de si como um corpo é possível a partir do momento que se reconhece o outro como tendo um corpo. Neste reconhecimento está a função indispensável do outro, procurador do Outro, para reconhecer o desejo. É o axioma do desejo de desejo, instaurador do circuito pulsional (LACAN, 1999, p.206). Conforme apresentado no Capítulo 2, o arco pulsional tem origem na fonte que, por sua vez ascende ao estímulo gerando, por acúmulo, pressão. Por fim, temos a descarga geradora de satisfação.

Eis o sentido da cativação que o outro exerce sobre o filhote do homem! A imagem antecipa a unidade, superando a fragmentação percebida, e possibilitando a identificação narcísica. Sendo o corpo uma coisa e a imagem deste corpo outra, a unidade conferida àquele e por esta antecipa no nível psíquico a futura unidade corporal. A imagem faz superar a distância entre o avanço psíquico e a organização biológica. A fascinação é essencial para que isso ocorra e se dê a constituição do $e u$ (LACAN, 1985, p. 70). Esta é a base que alicerçará as relações imaginárias, com os pares, com seu mundo. Desenhada primitivamente, a mudança do ciclo vital criou esta solução para a profunda desadaptação do homem ao seu meio.

Havendo esta discórdia primordial imposta pela maturação do organismo, delator do inacabamento anatômico do sistema piramidal e de certos resíduos humorais do organismo materno, o filhote do homem dá sinais do mal-estar e da incoordenação motora que o lança ao nascimento mergulhado por uma verdadeira prematuração (LACAN, 1998, p. 100).

O desenvolvimento é vivenciado de maneira dialética. O impulso interno conflui da influência da imagem do semelhante para a antecipação de um $e u$. Há uma ortopedia do $e u$, cuja identificação constitui o engodo necessário para domar o despedaçamento do corpo. Este último resiste na fantasia, embora seja contida pela rigidez de um eu arrolado de modo imperfeito. Este eu-fachada relaciona-se com o mundo externo, desconhecendo, em certa medida, o mundo interno, embora sofra seus efeitos.

A quadratura que Lacan convoca no Estádio é a referência explícita a um problema insolúvel. Não há possibilidade de fazer coincidir a imagem do corpo com a realidade, do mesmo modo que não é possível construir um quadrado com régua e compasso cuja área seja 
igual à área de um círculo. De fato, o inconsciente escapa radicalmente ao que no homem é possível circunscrever como eu. Este é o principal legado de Freud: o inconsciente.

\subsection{Where is my mOther?}

A divisão do $e u$ em (moi) e (je) revelada pela análise estabelece que é justamente o mais não-reconhecido no campo do $e u$ (moi) que é o inconsciente (je). Lacan relê o inconsciente freudiano fazendo-o um Outro. É o sujeito descentrado em relação ao indivíduo. Contudo, urge distinguir melhor este outro encarnado do Outro da linguagem.

Do outro ao Outro, Lacan colocará o inconsciente estruturado como uma linguagem, sendo seu sujeito efeito do significante. Este ponto é essencial para a articulação do sujeito, pois assim como o eu, o sujeito não é dado de saída. É ainda mais evanescente, posto que o sujeito é constituído a partir do momento da fala, não antes, no desenrolar do plano simbólico.

Superar a dimensão do outro para entrar na mansão do Outro é o marco decisivo em direção ao simbólico e à linguagem. Essa diz-mensãa $o^{8}$ é a entrada de uma nova dimensão, cuja intervenção no plano imaginário dará consistência ao axioma do sujeito estruturado como uma linguagem.

Ao dividir o eu em (je), (S), e (moi), (a), separa-se o sujeito que fala do sujeito como instância narcísica, e essa divisão não é sem efeitos. Ao (je) cabe o rigor do termo sujeito, termo que não se aplica mais ao (moi) sem comprometer a exatidão do conceito. Lacan (p.221, 1985) formula o sujeito da psicanálise como sujeito do inconsciente $(S)$, como sujeito que fala. Este sujeito está para além do ego (a). Cabe a este, como função imaginária, resistir; e é justamente nos efeitos de resistência que o inconsciente deixa-se apreender, já nos alertava

\footnotetext{
${ }^{8}$ LACAN, J. Televisão; in.: Outros Escritos, Jorge Zahar Editor, Rio de Janeiro, 2003, p. 514. Segundo nota do tradutor brasileiro de Outros Escritos, o neologismo dit-mension é homófono de dimensão, abarca "menção" e "dito" na mesma estrutura fonética. A aproximação ao termo mansão (mansion) não se dá por acaso. Quando Freud buscou no "estranho familiar" (FREUD, S. $O$ 'estranho' (1919); in.: Edição Standard Brasileira das Obras Psicológicas Completas de Sigmund Freud, Editora Imago, Rio de Janeiro, 1980) uma dimensão nova para a interpretação do inconsciente, reduziu do "estranho" (unheimliche) ao eu sua casa (heim).
} 
Freud nos seus escritos técnicos. Nesses termos é que a resistência não é propriamente do sujeito, mas um efeito do $e u$.

É necessário introduzir um corte para o sujeito, função simbólica por excelência, presentificar-se, e dele extrair consequências. Temos então a notação de sujeito do inconsciente por (\$) para denotar-lhe a marca do recalque. É justamente pelo fato do eu resistir, de haver dessemelhança entre o (je) e o (moi), que os efeitos da comunicação no nível do inconsciente são apreensíveis. Aí mesmo, no equívoco, no duplo-sentido, ocorre a tensão do eixo imaginário, lançando-o para mais além da significação. Este é o corte que o muro da linguagem faz operar por meio do simbólico, possibilidade do sentido deslizar pelos significantes em busca da significação, sem, contudo, estabelecer relação de identidade entre significante e significado. Não é por menos que Lacan retoma as leis da via Regis, descritas por Freud (1900) na Interpretação dos sonhos como condensação e deslocamento, renomeando-as nas figuras da metáfora e da metonímia. Assim, Lacan tira o inconsciente das trevas para a flor da linguagem, sendo o sujeito do inconsciente efeito do corte da linguagem. Nestes termos é que o simbólico cria ruído no sentido da compreensão, tão caro ao imaginário, conferindo à mensagem o estatuto de discurso interrompido; interrompido, mas insistente.

Essa delimitação traz mudanças radicais na compreensão da técnica, dando uma dimensão nova à direção do tratamento. Assim nos diz Lacan (1985, p. 311):

Há dois sentidos a dar à frase de Freud - Wo Es war, soll Ich werden. Este Es, tomem-no como sendo a letra S. Ele está aí, ele está sempre aí. É o sujeito. Ele se conhece ou não se conhece. Isto nem sequer é o mais importante - ele está ou não está com a palavra. No fim da análise, é ele quem deve estar com a palavra, e entrar em relação com os verdadeiros Outros. Ali onde S estava, lá tem de estar o Ich.

Então, temos, onde isso $(S)$ estava, eu, sujeito do inconsciente (\$), deve advir. Ocorre um descentramento do eu. Com isso, onde deveria eu (Ich) surgir, deverá advir o sujeito, (je), agora marcado pela barra do simbólico (\$). Desta feita, ao (moi) não é mais legítima a denominação de sujeito, como vimos, posto que a instância narcísica é-lhe mais afeita. A demonstração da relação imaginária estabelece a função do outro especular (a') como apoio 
ao desenvolvimento do eu (moi, ego, a) e do sujeito propriamente dito ( $\mathrm{S}, j e, \$$ ). Termos que em absoluto coincidem, embora o primeiro ofusque o segundo na dimensão da fala ordinária. O corte inserido nesta relação imaginária desloca o eixo da análise não para a identificação com um ideal ou com um par, mas para mais-além. Eis a dimensão simbólica, via do desejo.

Incide, daí, a barra sobre o $(S)$, tornando-o sujeito do inconsciente $(\$)$. É fundamental a incidência do corte, operado pela ação de um Outro, para do sujeito pulsional $(S)$ acéfalo advir o sujeito do inconsciente $(\$)$, interrogado sobre sua falta, seu desejo.

\section{5 É uma barra! Faz sentido. Tem outro sentido? Não-sentido...}

Lacan (1985, p. 221) confere ao nível em que o símbolo surge a parte essencial da experiência humana, a ocorrência do sujeito enquanto sujeito da fala, do inconsciente. Essa barra, desvelada pela experiência psicanalítica, revela uma profunda divisão do $e u$, sede do desconhecimento e da descontinuidade inerente ao $e u$; posto que não há equivalência possível entre os fatores da divisão - não havendo equivalência nos termos da divisão o quociente nunca pode ser igual a Um. Este Um é aquele momento mítico proposto por Freud (1950 [1895], p. 403) no Projeto do qual deriva o objeto perdido. Nesta álgebra há um termo (traço de memória) que se preserva e há um termo jamais encontrado, cuja ausência impõe um eterno retorno ao traço da falta. É a perda do ser operada pela ação do significante. Esta é a parcela do vivo que se perde ao ter acesso à linguagem. Para tanto, temos o efeito de borda sobre duas faltas, uma simbólica, que ora tratamos pelo significante, e outra real, dada de saída pela perda do ser justamente por ser sexuado. Desenvolveremos oportunamente este tópico, mas já destacamos que esse ponto é crucial para a virada do pensamento lacaniano sobre o estatuto do objeto. Estão lançadas as bases onde se desenvolverá a tese que o objeto do desejo é inexistente, havendo, sim, objeto causa de desejo, redirecionando a teoria e a prática da psicanálise. 
A barra que divide o sujeito é a do recalque, da castração, da impossibilidade do significante representar plenamente o significado, posto que o referente é abandonado para tornar a significação possível, como desenvolveu Lacan a partir da torção do esquema de Saussure (1996, p. 500).

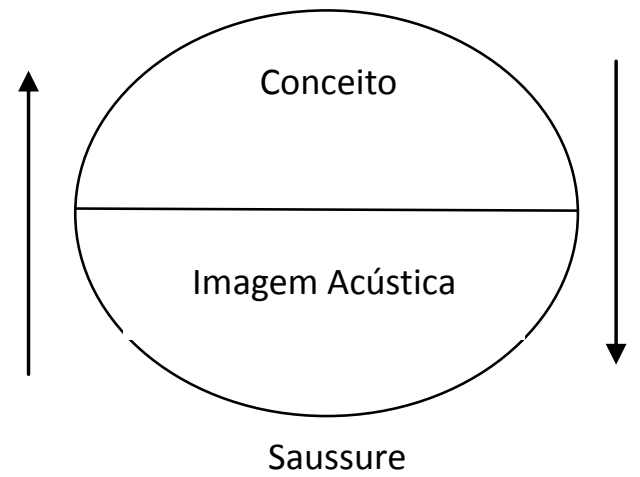

Significante

Significado

Lacan

A barra do recalque é a mesma marca que confere ao sujeito a impossibilidade de representar-se plenamente pelo significante sem o efeito de afânise, de desaparecimento (LACAN, 1985, p. 197).

A dialética do sujeito é instituída nesta divisão fundamental, sob os efeitos da alienação. Como isso se dá? Ora, se a cadeia significante está primeiramente no campo do Outro, então é a ação dela sobre o corpo do ser vivente que possibilitará surgir um sujeito, pela ação do significante, que extirpa o instinto do vivo e lança o sujeito à pulsão. Este processo ocorre de forma circular e assimétrica, uma hiância mesmo. O significante é produzido no campo do Outro e ao tocar o vivo produz um sujeito de sua significação. A sucessão temporal retoma este efeito a outro significante, encerrando o sujeito como significação possível a partir do desaparecimento, do fechamento da abertura do significante.

Um significante $\left(\mathrm{S}_{1}\right)$ só produz efeito em cadeia, em oposição a outro $\left(\mathrm{S}_{2}\right)$. Então o sujeito para ter significação deve desaparecer em $\left(S_{2}\right)$. Reparem que ao atrelar o sentido a outro significante, esse cai, escorrega para o campo do Outro. 
O sujeito é estrangeiro ao $e u$. Há um hiato que rasga o $e u$ sem que lhe seja possível uma síntese. O descompasso imposto entre a imagem e o motor garante para o eu um desconhecimento de si, embora íntimo: este estranho, o inconsciente. Não obstante, este eu rudimentar necessita do reconhecimento de si pelo outro (a') para ter assegurada sua imagem. Assim, a mensagem vem invertida do Outro (A). Com este (A) o eu estabelece uma profunda dependência. Na impossibilidade estrutural de (A) oferecer um significante que represente plenamente $(S)$, temos a barra recaindo em $(\AA)$ e depois em $(\$)$.
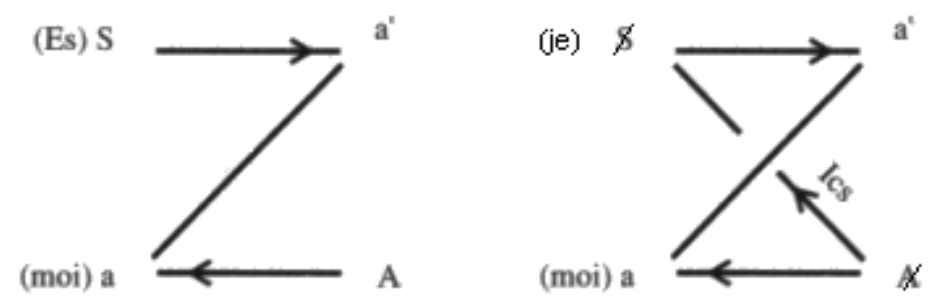

Eis o eu como uma construção imaginária, sendo o sujeito impossível em sua totalidade. O sujeito $(S)$ não se reconhece como dividido, apresentando-se como tal em um momento de abertura após um trauma no Outro ${ }^{9}$. $(S)$ se vê de (a'), garantindo-lhe um eu (a). Somente uma interrupção neste circuito imaginário, dependente da imagem, possibilita a função simbólica do sujeito $(\$)$ advir com seus efeitos. $\mathrm{O}$ recalque incide sobre a verdade do sujeito.

O eixo (a - a') é o eixo da identificação narcísica, registro do imaginário. Esse eixo é cortado pelo simbólico $(\mathbb{A}-\$)$, que instaura a dialética do sujeito do inconsciente. Temos então, como dito anteriormente, na instância narcísica a possibilidade do eu investir como objeto.

\footnotetext{
${ }^{9}$ FREUD, S. Análise de uma fobia em um menino de cinco anos (1909); in.: Edição Standard Brasileira das Obras Psicológicas Completas de Sigmund Freud, Editora Imago, Rio de Janeiro, 1980. Lembremos com Freud que o traumático é a castração no corpo do Outro. É precisamente após a visão (imagem) do corpo da mãe marcado pela falta do órgão fálico que Hans desenvolve toda a paixão de sua fobia. Como o outro (a') acusou a falta e o operador fálico era por demais insatisfatório para amarrar o sujeito a seu desejo, o menino demandou algo mais para tornar o Outro suportável: juntou um cavalo a seu pequeno pipi.
} 


\subsection{Espelho, Espelho meu, existe alguém mais bela do que eu?}

O desenvolvimento da teoria do narcisismo proposta por Freud impôs uma leitura absolutamente original da constituição do sujeito e suas relações com os objetos, justamente por tomar o $e u$ como objeto de investimento da libido. Lacan destaca que o eu é uma forma de constituição dos objetos, tendo a particularidade de sê-lo a partir do semelhante e de modo especular. Há, de fato, no eixo (a - a') uma superposição das imagens. No plano do espelho há a simetria dos dês $e g o^{10}$ e de seus semelhantes. A desigualdade interpõe-se e instala-se pelo muro da linguagem. A esfera imaginária do (moi), deste $e u$ verificável, e do semelhante confere a ambos o estatuto de objeto (LACAN, 1985, p. 307).

Atentemos para o fato de que o (moi) não é a visada da análise, pelo menos de uma análise lacaniana. $\mathrm{O}$ descentramento do $e u$ é o ponto de torção quanto à direção do tratamento destacado acima. Contudo, nisso não há uma relação de menos valia para com o plano imaginário, para seus efeitos no corpo, ou algo que justifique uma menor importância ou desqualificação da apresentação dos fenômenos deste registro. Muito pelo contrário. Precocemente, Freud (1893 - 1895) percebeu que um sistema pode obter prazer de modo distinto do de outro, ou seja, onde há sofrimento para o eu pode haver satisfação para o isso ${ }^{11}$.

\footnotetext{
${ }^{10}$ LACAN, J. O Seminário - Livro 2, o eu na teoria de Freud e na técnica da psicanálise, Jorge Zahar Editor, Rio de Janeiro, 1985. Segundo nota da tradução brasileira: des ego (eu) é homofônico com des éguaux (iguais). Para preservar tal efeito, mantivemos o termo no original, p. 307.

${ }^{11}$ Hanns, em seu dicionário (HANNS, L. Dicionário comentado do alemão de Freud; Editora Imago, Rio de Janeiro, 1996, p. 262), observa que, no alemão corrente, o eu (ich) só pode abordar o isso (es) como a um terceiro, destacando a alteridade deste com relação àquele.
} 
Lacan (1985, p. 56) atribui ao eu a função significativa no discurso, pois sendo imagem está preso à cadeia de símbolos. A montagem do eu é possível pela ação do significante na carne. O significante pode então representar o sujeito, esse desencarnado, para outro significante. Temos o inconsciente estruturado como uma linguagem e o sujeito efeito do significante.

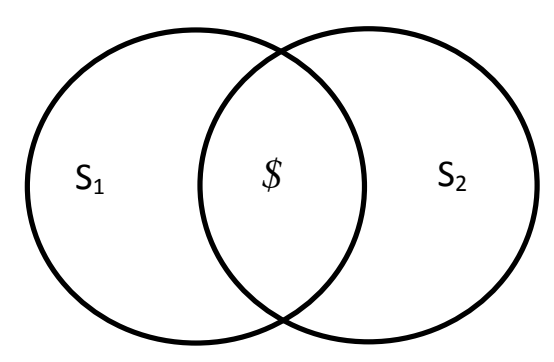

Deste modo, o eu é matriz simbólica do sujeito, conforme vimos anteriormente, e, nesta interseção, conjugam-se a alienação - a fala ego-orientada do discurso comum - e a realidade dividida do desejo. Esta divisão é a maior intimidade possível com a morte, pois, na hiância, a morte se presentifica, alienando o sujeito, colocando na boca mesma da fenda o que o causa.

O termo de interseção é comum aos dois conjuntos. Temos o desejo do Outro apreendido pelo que falta ao sujeito e também pelo que falta ao Outro. O que leva a mãe a atender o apelo da criança? Se a mãe direciona-se à criança é porque nenhuma possui o objeto que atribui ao ser da outra. O objeto da perda primeira é o mesmo da perda do Outro. As duas faltas se sobrepõem, juntando desejo do sujeito com desejo do Outro (LACAN, 1985, p. 200).

Eis a separação, momento segundo da alienação, na lógica da dialética do sujeito. $\mathrm{O}$ sujeito aparece primeiro no campo do Outro, na proporção em que o significante primeiro é o Unário, e na medida em que representa o sujeito para outro significante produz em afânise o sujeito enquanto significante binário. A alienação é a entrada do sujeito no significante, e a separação, a saída do Outro, inaugurando o campo mesmo do sujeito. Ocorre depois um retorno ao primeiro termo, da alienação. Um retorno circular, mas não simétrico.

Quando Lacan (1999, p.153) compara o inconsciente à tipografia é para acentuar que pode uma letra faltar. É precisamente no modo como se articula esta falta que a lei simbólica 
pode ou não operar. O significante está no campo do Outro e deve, em relação a outro significante, representar um sujeito, constituindo este Outro um terceiro termo essencial quando alguém fala.

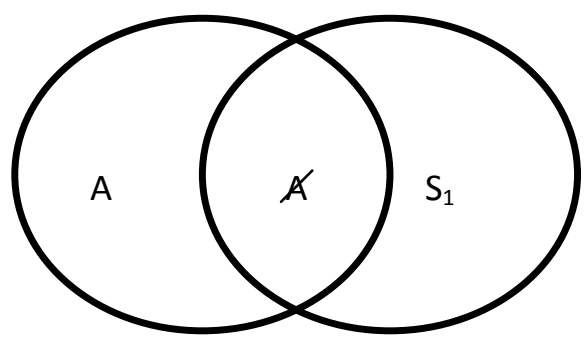

Deste modo, o desejo deve passar pela via do significante para encontrar o Outro. Um Outro desencarnado, pois é no desvio de direção, quando se muda de meio, que o desejo adquire um significado distinto do original. Isso não é sem consequências, pois toda satisfação possível do desejo encontra um ponto tangente em (A), infligindo uma perda quando da articulação da fala com o sistema significante assentado no Outro. O Outro intervém no sujeito na medida em que ratifica sua mensagem, invertendo-a. O desejo só é possível de se constituir na medida em que há uma relação do sujeito com o significante, com o campo do Outro (LACAN, 1985, p. 242). Neste campo, o traço unário desenvolve sua função de ideal do eu, objeto de identificações, superando na imagem a fragmentação do vivo. Este traço não é propriamente o significante, na medida em que não está na bateria significante. Este traço é signo de assentimento ao Outro (LACAN, 1992, p. 344).

O desejo fica condenado a um para-além da linguagem, realizando-se no tropeço, no ato-falho, nos sintomas e em outros lugares não sabidos. A insistência do significante denota o fato do desejo, em razão mesmo do significante, não poder ser significado. O Outro é, assim, mais do que o depositário fiel de todos os significantes possíveis, mais do que todos menos-Um. Não por outro motivo o objeto faltante (a) causa o sujeito, não o completa. Por não haver uma inscrição plena de $\left(S_{1}\right)$, nem no campo do sujeito nem no campo do Outro, (a) não é encontrado. É em relação à (a) que o sujeito orbitará no desejo, na fantasia e em todas as suas relações. Por este motivo Lacan colocará o objeto (a) no centro do nó borromeano. 


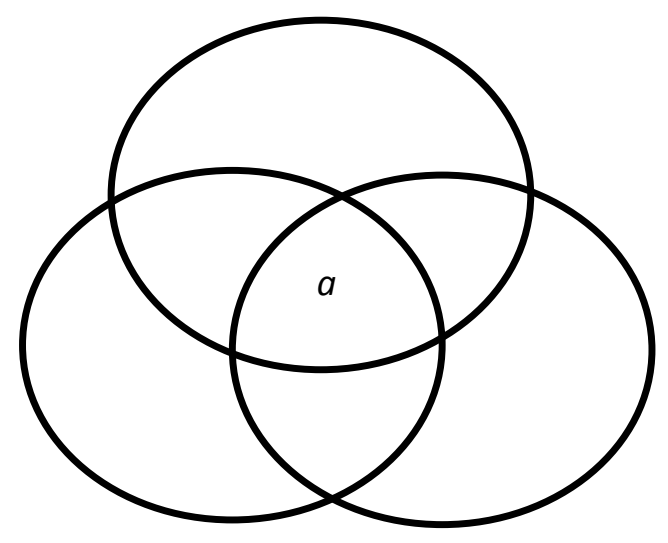

Mas e o desejo, como introduzi-lo nesta dialética do sujeito e das funções do $e u$ ? Iniciemos pela relação da criança com a mãe. Aquela depende primitivamente do desejo da mãe. Alguma diferenciação começa a fazer-se na medida em que a mãe deixa de ser este ser absoluto e afirma-se como presença e ausência; ponto esse amplamente debatido por Freud no jogo do fort $d a^{12}$, cuja articulação amplia a compreensão da relação de atividade/passividade e do simbólico como meio de modulação da angústia. A nova perspectiva teórica desenha uma evolução importantíssima para estabelecer uma função de desejo neste pequeno ser. O desejo é para o infante o desejo de desejo da mãe. É a dilatação do que a mãe deseja objetivamente para o que ela deseja num mundo de símbolos. Na medida em que a presença/ausência possibilita a entrada para a criança do desejo da mãe, e este é voltado para Outra coisa, temos a rudimentar simbolização que algo do desejo dela não se satisfaz no desejo dele bebê. Aí, insere-se a abertura para a vida e para uma forma de gozo mediada pelo falo, retirando algo do gozo no corpo na medida em que introduz a ação simbólica. Lembremos que o processo primário estabelecido por Freud é, segundo Lacan, o gozo, mas veremos isso mais adiante. A ação significante instaura o processo secundário, uma vez que no aparelho psíquico estão os representantes da pulsão.

O falo é um arranjo possível justamente pela negatividade. É na medida em que algo falta que ele pode ser utilizado como instrumento para positivar justamente o que não há. São as próteses, seus usos, confecção e transmissão, que ancestralmente nos acompanham, conforme assinalado no Capítulo 1, como fator denunciante de uma nova função psíquica. As

${ }^{12}$ FREUD, S. Além do princípio do prazer (1920); in.: Edição Standard Brasileira das Obras Psicológicas Completas de Sigmund Freud, Editora Imago, Rio de Janeiro, 1980, p. 26. Optamos por manter o termo no original em alemão uma vez que esta foi a opção da tradução brasileira, além do vocábulo ser consagrado na literatura psicanalítica. 
próteses estão envolvidas no complexo de castração! Com Lacan (1999, p. 190), podemos pensar que este objeto faltante, que abre espaço para as próteses, para o trabalho, é uma necessidade da ordem simbólica. A relação da criança com o objeto falo se estabelece na medida em que é este objeto o que a mãe deseja. Se o deseja, é porque dele é privada. Entra em cena o operador da castração, o pai como aquele que priva a mãe do objeto de seu desejo. Está aberta a possibilidade da dialética do ser/ter o falo, estabelecendo o terreno de onde um sujeito poderá se situar na encruzilhada estrutural.

Há aqui um ponto importante na articulação: o pai não pode de modo algum castrar a mãe de um objeto que ela não tem. O objeto é lançado para um plano simbólico, registro onde se desenrolará a trama da significação da privação. Eis o que Lacan chamou de ponto nodal do Édipo, encruzilhada estrutural, pois é a privação do falo que a criança aceita ou recusa. Ter ou não ter o falo decorre do fato de ser castrado. Acentua-se que o que é castrado é antes a mãe do que o sujeito em questão. Conforme vimos, a barra incide primeiro no Outro para depois recair sobre o sujeito. Não é demais lembrarmos que a mãe é para a criança, pelo menos inicialmente, o Outro (mOther).

\subsection{Três tempos para um desejo}

Dada sua condição, a criança é, a princípio, um assujeito. O desejo surge de forma articulada, sujeito à lei do Outro. É instaurada uma dependência do sujeito ao significante, de modo que aquele não existe sem que este o funde. $\mathrm{O}$ caminho em direção à castração acentuase com a indicação da mãe de que o falo oferecido - a criança identificada com o falo, ser o falo - é insuficiente, esvaziando a identificação imaginária com o mesmo. O desejo da mãe encontra morada alhures, em algo que o pai pode lhe dar. O filho é, para tanto, impotente, não é mais o falo, pode, no máximo, portá-lo, mas não mais sê-lo.

Temos então três tempos. Um primitivo, onde o sujeito identifica-se imaginariamente

com o objeto do desejo da mãe. É o axioma do desejo como desejo de desejo, onde na equação aparece o (D) como desejo da mãe, e o [D(D)] como o desejo desejado pela criança. Neste momento a criança é impotente frente a este Outro que ora está presente, ora ausente. 
Assim, o falo como objeto desejado pela mãe assume um lugar privilegiado na dialética subjetiva, pois é em torno dele que o sujeito vai se organizar. Mesmo sobre a égide do imaginário, o símbolo e a lei já se fazem presentes, uma vez que o falo é um objeto metonímico situado na cadeia significante, chave lógica que nos permite ascender ao segundo tempo.

O segundo tempo é marcado pelo encontro do sujeito com a lei, mesmo que ainda sob sua expressão imaginária. A percepção de que a mãe deseja um outro objeto situa este mesmo objeto no campo do Outro. Há um Outro do Outro? O sujeito pode superar a identificação primitiva, desidentificando-se deste objeto, colocando seu (je) no lugar da mãe e o (je) dela no lugar do Outro para si. Temos a dialética operada pelo falo! O Outro é marcado pela falta e esta recai sobre o sujeito na medida em que ele não é mais este objeto que sutura a fenda do Outro. Para tanto, é necessário que haja uma proibição no desejo da mãe para que o filho salve-se de ser este objeto e possa ser um sujeito. Há uma nova ordem em funcionamento: a mãe não é completa e ainda está submetida a uma lei. A relação com o pai é a entrada dos Nomes-do-pai, que tem na metáfora paterna sua máxima expressão como significante (LACAN, 2005, p. 73). É a ruptura com o lugar ideal que a criança pode, como falo, ocupar no desejo da mãe que possibilita o terceiro tempo, um tempo de identificação com o pai.

O terceiro tempo é marcado pela identificação ao Ideal do $e u$, identificação com aquele que tem o falo. Esta operação é estabelecida pelo significante. A cadeia significante está presente desde as origens como Outro e faz suas exigências à subjetividade, impondo uma barra ao Outro em sua constituição. É ao termo desta etapa que temos a assunção do $(\Phi)$ enquanto simbólico e do $(-\varphi)$ enquanto imaginário, estabelecendo os dois registros da função fálica. Temos o declínio do complexo de Édipo quando a identificação possibilitada por aquele que tem o falo opera no sujeito. Este, se masculino, pode reclamar para si um falo; se feminino, vai situar-se ao lado daquele que é suposto tê-lo (LACAN, 1999, p. 202).

A identificação ao falo é uma forma de satisfazer o desejo da mãe. Há toda uma gama de identificações possíveis, mas encontram limite precisamente na formação do Ideal do $e u$, momento em que opera o registro simbólico através do significante privilegiado que é o Nome-do-pai, com sua função proibidora. Esse significante representa o conjunto de significantes autorizados a existir e regidos por uma lei. Em oposição está o falo, significante 
da significação. O significante fálico surge precocemente na medida em que é necessário abordar o desejo da mãe e, quando lá se toca, este lugar já está ocupado. Então para o ser humano ter acesso ao desejo é necessário, de saída, suportar a perda imposta pela ausência de objeto. Por isso que o significante tem relação com a falta de objeto, ponto que estamos explorando desde os precursores da pulsão. Quando o instinto perde o objeto pela ação do significante, temos a abertura do campo pulsional.

É dura a entrada no mundo do desejo! Há uma lei imposta e esta relança o objeto para mais-além de um ponto tangível. O objeto do desejo é irrealizável posto que é causa de desejo. O Nome-do-pai garante que haja uma lei, ordenando os significantes na medida em que faz do falo o ponto de basta. Se o gozo deve contornar o falo operando, necessariamente, uma perda, para nesta fazer-se o circuito pulsional, é fundamental para tanto suportar a frustração da fraqueza que o falo representa. O falo traz a pecha de ser marcado pela impotência de ser realmente o objeto, no máximo um substituto canhestro.

\subsection{Sexo e morte}

A reprodução sexuada impõe às espécies que evoluíram para este modo de reprodução a morte do indivíduo, testemunhada pelo que a biologia celular descreve como apoptose (FREUD, 1920). O sexo atinge o vivo pela via biológica, já o sexual é introduzido no sujeito através das marcas da falta pela via do significante. Não somente uma, mas duas faltas se sobrepõem quando se referem ao sujeito. Como vimos, o sujeito depende do significante que está originalmente no campo do Outro. À falta de significante acresce-se a falta originária, real, imposta pela condição de sexuado. É a perda real que a sexualidade impõe à vida. Neste sentido que o objeto da pulsão, objeto (a), suporta a emersão do sentido do sexo, arauto da presença da morte, pela função mesma do significante.

$\mathrm{Na}$ constituição do sujeito é de fundamental importância a relação deste com o objeto. Há em Eros uma tensão rumo ao Um, tensão confirmada pelo caráter narcísico da escolha de objeto suportada pela ação do significante. A demanda de amor pede sempre mais amor, denunciando a insuficiência da resposta que vem do Outro. 
Ao ser, o desejo não produz resposta suficiente, já que nos conduz sempre rumo à falta do ser. Eis o ponto que se demonstra a hiância entre o Um e a falta-a-ser. Incide aí a marca do gozo, pois à imagem escapa um resto no qual reside a insatisfação basal do desejo (LACAN, 1985, p. 14).

Temos um furo na orientação da demanda de amor. Esta, busca o ser, coisa extremamente fugidia na linguagem, sendo mesmo irrepresentável, pois reafirmamos, com Lacan (1985, p. 37 e p. 280), que o sujeito não é de ordem ontológica. Daí o amor apresentarse como suplência à falta de relação sexual (LACAN, 1985, p.62,). O que está em questão é o que suporta o sujeito na falta de relação. Neste termo, cada um se relaciona com o objeto (a) constituído sob o olhar do outro. Não há um casal e sim uma tríade sempre que dois indivíduos se encontram. O casamento traz a marca da imperfeição do Um mais (a), pois não há como os pares se sustentarem sem a referência a um Outro e o objeto (a) que os causa.

O Um só pode ser admitido como significante como tal, apartado dos outros, separado dos efeitos de significado. Deste modo, o sujeito, como efeito dos significantes em oposição, deixa de operar como ruído na cadeia significante. É precisamente o efeito intermediário entre um significante e outro significante, a cuja barra articula-se a função fálica, que localiza o sujeito.

Chegamos então à proposição de que o aparelho psíquico é um aparelho de linguagem, desenvolvido para aparelhar o gozo, este resto insistente que nunca se inscreve no aparelho psíquico. Sua existência é denunciada justamente no que claudica na fala, pois é na ausência de representação que o gozo fala, no momento que ascende a uma tradução, fala de outra coisa. Eis a mola da metáfora; este algo que vem do real como o (a).

Em torno deste objeto organiza-se a sexuação, da qual decorre a possibilidade de o sujeito situar-se como homem ou mulher, segundo a orientação deste objeto mesmo, o objeto (a). Temos o significante barrando o gozo na medida em que se articula em cadeia significante, quando é representado; e temos também o gozo do significante na proporção em que não demanda do Outro, mas dele se desvincula, desarticulando a cadeia, reduzindo-se, por assim dizer, ao significante puro.

O gozo é o mais-além do limite extremo da experiência; já o desejo, inscrito por uma função corporal, o remédio que barra o gozo (LACAN, 1985, p. 124). Há um $\left(\mathrm{S}_{1}\right)$ que 
necessariamente não é inscrito, comprometendo a leitura do inconsciente como morada das representações. Eis o ponto tipificado pelo umbigo dos sonhos na metáfora freudiana da Interpretação..., resistente a qualquer recurso significante (FREUD, 1900, p. 428). Resiste como algo indefinido entre o fonema, a palavra e até mesmo o pensamento, aproximando-se da tese freudiana da percepção (W), onde são iniciadas as estimulações. Estas constituem a origem, embora não deixem marcas no aparelho psíquico senão por sua ausência.

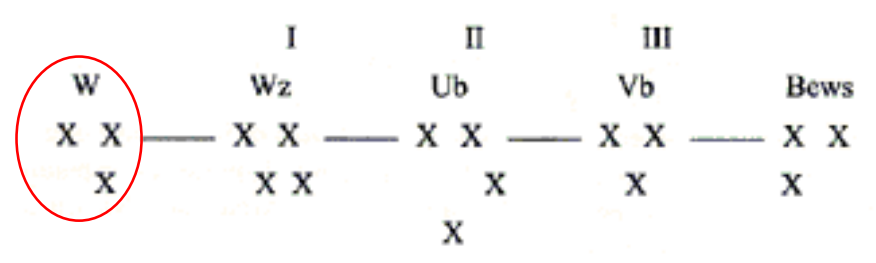

(Modificado de Freud, 1980 [1896], p. 282)

A diferença dos sexos é encarnada pela anatomia dos organismos vivos. O organismo é dividido em dois sexos, macho e fêmea, mas isso pouco acrescenta à compreensão da escolha dos parceiros. Deste modo, temos na significação da diferença dos sexos a melhor explicação para o desejo no humano, ou seja, como se situar frente à castração. Essa significação, particular para cada sujeito, traz no Outro os nomes de cada cultura. Ser homem ou mulher é, antes de uma determinação do cromossomo, uma resposta ao Outro. Temos no apelo aos instintos uma franca insuficiência explicativa pertinente à própria natureza do objeto causa de desejo, este objeto (a).

Há muito abandonamos o cio, aquele estado biológico que leva os animais a buscarem acasalamento e a fêmea a aceitar o macho (HOUAISS, 2011, p. 723), e ficamos com os enigmas do desejo sexual marcado pelas pulsões. Devido a sua plástica, as pulsões apresentam toda uma sorte de destinos, tendo na satisfação parcial um meio de realização, cujo alvo recai ao sabor de cada sujeito, nas mais amplas possibilidades. O inconsciente não é orientado pelas categorias da biologia, ante as quais as representações e as pulsões parciais não oferecem respostas. 
O descompasso sofrido entre o biológico e sua representação é devido ao fato de haver um corte, uma inscrição irreversível da sexualidade sobre a natureza. O ser sexuado é uma exigência da linguagem. Situa-se para além do corpo, do organismo vivo, confirmando a ausência de complementaridade entre sujeito e o objeto. Assim, não há no mundo natural objeto capaz de satisfazer plenamente o desejo sexual. Isso confere ao desejo, desde Freud, um caráter indestrutível (FREUD, 1905, p. 158). Atentemos ao fato de ser justamente sujeito $(\$)$ e objeto (a) os termos presentes na fórmula da fantasia ( $\$ \diamond \mathrm{a}$ ). A relação entre os termos não é outra senão de aproximação $(\wedge)$ e afastamento $(\vee)$, como indicado pela figura $(\diamond)$. Portanto, a própria fórmula da fantasia exclui a relação de complementaridade (LACAN, 1985, p. 198), portanto, a marca da divisão só é transponível com uma ação que faça desaparecer o sujeito, desarticulando a estrutura da fantasia (LACAN, 1992, p. 326).

A diferença anatômica é reduzida à problemática fálica para, da significação de um órgão do corpo, fazer-se o significante. É a cota de carne cedida para entrar no universo simbólico. As pulsões parciais desconhecem a diferença sexual, abrigando o inconsciente indistintamente, tanto o que é homo e o que é hetero, no campo da sexualidade, possibilitando a labilidade de satisfação na mesma medida que encerra a distinção de prazeres em registros diferentes (SOLER, 2006, p. 17). O que é vivido como prazeroso num sistema pode ser desprazeroso no outro, conforme já apresentamos.

A cultura encarrega-se de oferecer objetos, unindo o desejo sexual à linguagem sob a forma metonímica. Quando se chega a um objeto, aquele propalado como derradeiro, este, natimorto, já está superado por outro, enfim, o prometido. Percebe-se um deslocamento sem ponto de basta, cuja substituição de objetos não possibilita significação possível. Deste modo, a cultura pluraliza a oferta, sempre deslocando de um objeto ao outro, proporcionando contorno à falta, camuflando na produção, no uso e na transmissão dos objetos a insanável divisão. 


\section{NO FIM E NO COMEÇO, O GOZO}

O diabo não há! É o que eu digo, se for... Existe é homem humano. Travessia.

Guimarães Rosa

Nos capítulos anteriores, acompanhamos a ação do significante sobre a carne, cuja resultante é a transformação desta em corpo. Com esta transformação, percebemos o apagar dos instintos e o nascer das pulsões. Assim, uma nova ordem se estrutura ao desenhar um para-além da natureza, lançando o bicho-homem à uma realidade linguageira e totalmente original para as espécies vivas. A tese defendida até aqui é que a dimensão propriamente humana dá-se com a estruturação do inconsciente, oferecendo uma hipótese para compreensão da escansão na linha evolutiva chamada pelos neodarwinistas de Grande Salto para Frente (DIAMOND, 2012).

Somos os únicos animais conhecidos que lidam com um organismo além-biológico. Sendo o corpo efeito da marca singular do significante sobre a carne do vivente, podemos afirmar que o corpo é metabiológico. Portanto, dada a insuficiência do conceito de instinto para abarcar a realidade da natureza dos homens, necessariamente haver-nos-emos com outro registro: o campo pulsional, inaugurado no pensamento científico por Freud. Para este, conforme desenvolvemos em capítulos anteriores, pulsão é um conceito limite entre o psíquico e o somático (FREUD, 1912), portanto não pertencente a nenhum dos dois campos, nem ao psíquico, tampouco ao biológico.

A pulsão tem origem no organismo e gera demanda de trabalho ao psíquico. Seguimos o esquema desenvolvido por Hanns (1999), a partir da teoria pulsional de Freud, para acompanhar todo o arco de sua trajetória. A pulsão afeta o psíquico via representante pulsional, desenhando, assim, o aparelho psíquico como uma máquina de tratamento do excesso de excitação (resto nunca traduzido em representantes, conforme a Carta 52) produzido pela constância dos estímulos pulsionais. 
Rabinovich (2004) destaca a profunda intimidade existente no pensamento lacaniano entre os conceitos de corpo, pulsão e gozo. Como já tratamos anteriormente do corpo e da pulsão, tratemos do gozo agora. O presente capítulo buscará demonstrar esta referida intimidade.

\subsection{Do gozo vulgar ao jouissance}

Devemos lembrar que gozo não é um conceito freudiano. É um conceito lacaniano. Contudo, embora não esteja em Freud, é possível identificar elementos conceituais e, sem muito risco, afirmar que o conceito não é dele, Freud, mas desde cedo estava lá.

Tomemos Saroldi quando nos diz que "um dos pressupostos epistemológicos da psicanálise, seu apoio no mundo da experiência, seria a referência clínica" (BIRMAN, 2009, p. 16). Portanto, não é forçoso propor que, por desenvolver a psicanálise como método a partir da sua prática, Freud, mesmo sem dispor de ferramentas conceituais para desenvolver o conceito de gozo (ferramentas como a linguística saussuriana - que permitiu à Lacan situar o sujeito como efeito do significante, encerrando a confusão entre sujeito e eu e, de quebra, legando o conceito de indivíduo definitivamente a um lugar outro que não o da psicanálise - e a fenomenologia de Hegel), já apreendera o fenômeno ao perceber a existência de um resto persistente nunca simbolizado. Lacan (1998, p. 814), ao propor a Subversão do Sujeito, chega mesmo a afirmar que:

O inconsciente, a partir de Freud, é uma cadeia de significantes que em algum lugar (numa outra cena, escreve ele) se repete e insiste, para interferir nos cortes que lhe oferece o discurso efetivo e na cogitação a que ele dá forma.

Nessa fórmula, que só é nossa por ser conforme tanto ao texto freudiano quanto à experiência que ele inaugurou, o termo crucial é o significante, ressuscitado da retórica antiga pela linguística moderna, numa doutrina cujas etapas não podemos assinalar aqui, mas da qual os nomes de Ferdinand de Saussure e Roman Jakobson indicarão a aurora e a culminância atual, lembrando que a ciência-piloto do estruturalismo no Ocidente tem suas raízes na Rússia em que floresceu o formalismo. Genebra, 1910, e Petrogrado, 1920, dizem bem por que seu instrumento faltou a Freud. Mas 
essa falha histórica só faz tornar mais instrutivo o fato de que os mecanismos descritos por Freud como sendo os do processo primário, onde o inconsciente encontra seu regime, abrange exatamente as funções que essa escola toma por determinantes das vertentes mais radicais dos efeitos da linguagem, quais sejam, a metáfora e a metonímia, ou, dito de outra maneira, os efeitos de substituição e combinação do significante nas dimensões respectivamente sincrônica e diacrônica em que eles aparecem no discurso.

Ou seja, os elementos conceituais que possibilitam a sustentação do conceito de gozo estão presentes desde o início da teorização da psicanálise. Podem ser identificados já precocemente nos modelos de aparelho psíquico da Carta 52 e do Projeto... - onde se desenharam o modelo da perda estrutural do objeto, ou seja, perda de gozo. Destacamos que o objeto complementar, alcançável pela via dos instintos, mas perdido por estrutura, não por experiência, para o falante, leva Rabinovich (2004) afirma que o vivente é "presa da linguagem". Em contraste, temos a afirmação de Diamond (p.67, 2010) que diz "a palavra falada que nos fez livres". Ora, mais do que uma contradição, vemos um ponto de convergência: a palavra falada libertou o homem da Natureza e o aprisionou na linguagem.

Quando a linguagem barra o sujeito pulsional (S), fazendo-o sujeito barrado (\$), escapa-lhe um resto $(a)$. Perda fundamental do freudismo, inaugurada a partir do trauma, nascedouro do que mais tarde evoluiria para a teoria das pulsões e suporte do gozo. Esta perda será a matriz e o desencadeante de toda a repetição e da insistência da repetição. O que levará Lacan a afirmar que toda pulsão é pulsão de morte. É o resto nunca simbolizável que pressionará continuamente o aparelho psíquico.

Insisto: o objeto perdido freudiano (perdido por estrutura, não perdido por experiência) é o que motiva uma repetição (automaton e tyché diferenciadas no Seminário XI por Lacan) e é o que impulsiona para a descoberta desse objeto que nunca se teve.

RABINOVICH, 2004, p. 23 
Afirmamos que é do gozo, e do inconsciente como efeito do gozo, que a psicanálise digna deste nome trata, pois como quer Freud, inaugura-se a subjetividade pela experiência traumática da perda. Existe uma psicologia dos humanos, seja em qual abordagem for (humanista, behaviorista, cognitivo-comportamental, gestaltista, etc). Existe uma psicologia animal, seja do comportamento ou das emoções. Contudo, afirmamos categoricamente que jamais existirá uma psicanálise que não trate do humano, ou seja, do inconsciente e do gozo. Estamos, portanto, com Birman $(2009$, p. 29) na argumentação de que desde a sua origem "a psicanálise seria uma formulação diversa e diferente" do que se propõe como a ciência da psicologia. Ciência a qual Lacan (1998, p. 809) atribui o título de "rótulo" para, na sequência, recusar sua articulação na qualidade mesma de ciência:

O que recusamos. Precisamente porque iremos demonstrar que a função do sujeito, tal como instaura a experiência freudiana, desqualifica na raiz o que sob esse título só faz, não importa a forma de que se revistam suas premissas, perpetuar um contexto acadêmico.

Seu critério é a unidade do sujeito que existe com base nos pressupostos desse tipo de psicologia, nela cabendo até tomar como sintomático que seu tema seja cada vez mais enfaticamente isolado, como se se tratasse do retorno de um certo sujeito do conhecimento, ou fosse preciso que o psíquico se fizesse valer como duplicando o organismo.

Renovamos aqui nossas intenções em apresentar as contribuições da psicanálise sobre o olhar, embora agudo, insuficiente do neodarwinismo para apreensão do fenômeno humano no seu distanciamento da natureza e entrada na cultura. Para manter seu equilíbrio teórico dentro de uma coerência epistemológica, as ciências naturais procuram se afastar de construtos metafísicos. E com isso surge a necessidade de admitir um silêncio frente ao fato de estarmos biologicamente prontos e persistirmos culturalmente inertes por muitos anos e, repentinamente, darmos um Salto qualitativo (DIAMOND, 2010). 
A psicanálise, desde Freud, também se afastou da metafísica. Lembremos todo o desejo de cientificidade presente na pesquisa, na obra e na vida de Freud (GAY, 2005). O laboratório de Freud era a clínica, e ao desenvolver uma ciência com especificidades próprias, afastou-se da filosofia (metafísica) e da biologia (física), embora preservasse o empirismo clínico. Quinet (2000, p. 37), a esse respeito afirma:

\begin{abstract}
A psicanálise é uma antipsicologia, pois enquanto a psicologia, ao lidar com os processos conscientes, está imersa no reino do sentido, a psicanálise opera sobre o inconsciente, que dá prevalência ao significante - pois o significado nada mais é que outro significante que, junto com o primeiro, produz efeito de sentido. O significante é apenas o som da palavra esvaziado de sentido, como uma palavra estrangeira desconhecida ou o nome próprio que embora designe, nada significa.

[...] O que mostra que a associação de ideias se faz pela via do significante e não do significado. Eis o que a psicanálise permite apreender no esquecimento, no ato falho, no chiste, no lapso e também no sintoma que apresenta essa estrutura de linguagem.
\end{abstract}

Por ser a psicanálise a única ciência que trata do conceito de gozo, este só é alcançado teórica e clinicamente somente por meio dela. Acessado pela via da palavra, justamente por estar fora dela, conforme a demonstração cabal da relação do sujeito com o significante e seu resto, que escapole para fora da cadeia significante assumindo o lugar de objeto causa. Podemos afirmar que, como conceito, o gozo só existe para a psicanálise, e como experiência, só para o humano. Cassin (BADIOU, 2013) lembra que a ação do significante que nos dá acesso ao gozo vem à luz pelo equívoco, pelas formações do inconsciente, portanto, por força da estrutura: “[...] não se psicanalisa um cão, nem sequer um gato[...]. Os 'símbolos' da linguagem animal nunca são equívocos; os da linguagem humana, que há nos sons da voz e, ainda mais perturbador, nas letras (na letra), o são" (BADIOU, 2013, p. 19).

Portanto, o gozo só é presente no falante e, conforme buscaremos demonstrar, por sua ocorrência, um macaco exótico foi arrancado da evolução natural e lançado à condição de uma nova invenção: o Humano. Entendemos por falante o animal que perdeu o organismo dado à ação do significante e que, justo por isso, navega nos registros simbólicos da linguagem (Outro), no dia-a-dia com os pares (outro) e na lida com o inefável de seu ser (a), 
desde a origem, perdido. Para que não restem dúvidas, ser falante não é equivalente ao ser que vocaliza, mesmo que este último utilize um código complexo e flexível de símbolos.

Não podemos ignorar a lição deixada pelos linguistas. Assim como a ideia do abandono do referente nas palavras com funções exclusivamente gramaticais não justificaria por si o Salto, conforme argumentamos anteriormente, fala e linguagem não são confundíveis. A fala precisa materializar-se na palavra para presentificar a linguagem. Esta última, para Lacan, seria a articulação dos significantes entre si segundo as leis da metáfora e metonímia, descritas como mecanismos do funcionamento do aparelho psíquico por Freud nos termos de condensação e deslocamento. O Outro é a linguagem. Portanto, temos que a "fala implica o sujeito dirigir-se a Outro, implica o reconhecimento do Outro e a articulação, em palavras, da demanda e do desejo em relação a Outro" (QUINET, 2003, p. 43).

Birman (2009) é preciso ao destacar o alcance da inovação proposta pela psicanálise freudiana à ciência de sua época. Da necessidade de sustentação epistemológica, Freud deriva o conceito fundamental de pulsão como pedra angular da psicanálise. Sua mitologia. Lacan adverte que o mito psicanalítico das pulsões não é "uma remissão ao irreal", sendo sim uma mitificação do real que realiza justamente no mito "aquilo que produz o desejo, reproduzindo nele a relação do sujeito com o objeto perdido" (LACAN, 1998, p. 867). A nova ciência possibilita uma nova cobertura teórica sobre o fenômeno humano. Lembremos que autores neodarwinistas atribuem ao uso das palavras sem referentes o Salto que nos levou à humanidade. Esta tese, no extremo, aproxima pulsão e instintos, pois despreza a perversão que a linguagem gera nos instintos. Acaba por permitir, assim, um resgate adaptativo que os conceitos de pulsão e gozo tornam insustentáveis. Valemo-nos aqui desta cobertura para dar conta do hiato na linha evolutiva do homem inalcançado pelas ciências naturais, sem recorrer à metafísica. Nas palavras de Birman (2009, p. 43):

Assim, pelos pressupostos do discurso psicanalítico, o sujeito existia onde não pensava e, em contrapartida, pensava onde não podia efetivamente existir.

O que Lacan pretendia dizer com isso, afinal de contas? De que maneira transformou num paradoxo a oposição entre pensar e existir? Lacan pretendia dizer com isso, nada mais nada menos, que o sujeito existia no registro do inconsciente, no qual não pensava, pensando apenas, de acordo com o discurso freudiano, nos registros da consciência e do eu, nos quais não podia existir. Promovendo, portanto, a disjunção radical do filosofema do 
sujeito, em Descartes - penso, logo existo -, ao enunciar os diferentes espaços psíquicos onde o sujeito poderia efetivamente existir e pensar, Lacan demarcou rigorosamente $\mathrm{o}$ alcance filosófico da invenção teórica empreendida pelo discurso psicanalítico.

Por mais espetaculares e instigantes que possam ser os achados sobre o uso da linguagem em primatas, conforme apresentamos anteriormente, estes achados denunciam um uso instrumental da língua, sem constituir, de fato, linguagem. Os animais comunicam-se, nomeiam objetos, apresentam sotaques e até enganam uns aos outros com mensagens de relativa complexidade. Ludibriar é ato de vontade, oferecendo pistas da consciência e do pensamento no mundo animal. Consciência e habilidade cognitiva são objetos da psicologia, seja em qual espécie for. Estas funções psicológicas afirmam o centramento da consciência na psicologia no universo animal, configurando assim uma concepção de eu não-reflexiva (pois, refletir é tomar-se por um Outro e observar um significante que falta neste Outro $[S(A)]$ ), e termina por estabelecer a consciência como referência central da subjetividade. O destaque dado ao cogito (penso, logo existo) como característica diferencial do humano no reino animal reafirma a colocação da consciência como elemento central da subjetividade. Este modelo perde musculatura quando encara a descontinuidade da evolução, pois necessita da adoção da hipótese do Salto para sustentar-se. Lembremos que tal hipótese acertadamente atribui valor à linguagem como chave explicativa do despertar cultural. Contudo, estamos a argumentar que a tese de que foram as palavras com fim somente gramatical que nos libertaram da natureza é insuficiente. Buscamos demonstrar que as palavras inauguraram um novo campo, campo do Outro, e com isso uma nova ordem. Se o modelo do centramento da consciência ficara enfraquecido, simplesmente tal modelo liquefaz-se com a descoberta do inconsciente e da divisão subjetiva a partir de toda revolução freudiana.

O modelo proposto pela psicanálise descentra o sujeito da consciência, precisamente por fundar as bases conceituais da subjetividade no inconsciente. $\mathrm{O}$ acesso a este novo sujeito está precisamente nas vias permitidas pelo aparelho de linguagem (aparelho psíquico). As formações do inconsciente são justamente a demonstração produzida no laboratório do psicanalista: o divã. Portanto, equívoco é privilégio do significante exercendo função de significante e, para que ele opere como tal, é necessário a barra (do recalque), representada no matema lacaniano pela barra que separa significante de significado. Assim, permite-se o 
deslizar e, nesse, novas significações, nas fórmulas da metáfora e da metonímia (avanço lacaniano dos conceitos de condensação e deslocamento). Ou seja, aparelho psíquico em ação a demonstrar que o inconsciente é estruturado como uma linguagem!

Pelo exposto, temos, então, um novo sujeito na proposta psicanalítica. Um sujeito do inconsciente, dessemelhante de si e impossível de se inscrever na cadeia significante, posto que é efeito do significante. Portanto, o significante não oferece significado do sujeito, apenas o representa a outro significante. Assim Lacan (1998, p. 814) nos diz:

\begin{abstract}
Uma vez reconhecida a estrutura da linguagem no inconsciente, que tipo de sujeito podemos conceber-lhe?

Podemos tentar aqui, numa preocupação de método, partir da definição estritamente linguística do [Eu] como significante: onde ele não é nada além do shifter ou indicativo que, no sujeito do enunciado, designa o sujeito ele fala naquele momento.

O que quer dizer que designa o sujeito da enunciação, mas não o significa. É o que se evidencia pelo fato de que todo significante do sujeito da enunciação pode faltar no enunciado, além de haver os que diferem do [Eu], e não apenas no que é insuficientemente chamado de casos da primeira pessoa do singular, se lhe acrescentarmos seu alojamento na invocação plural e até no $S i$ da auto-sugestão.
\end{abstract}

Deparamo-nos, pois, com o campo entendido como metapsicologia (além da psicologia). Tese fundamental do freudismo que descentra o eu e a consciência dos fundamentos do psiquismo. Birman (2009) afirma que o pensamento freudiano constituía uma pesada crítica ao consciencialismo (campo no qual os neodarwinistas se situam até os dias de hoje), por reconhecer na metapsicologia do discurso psicanalítico "a existência do inconsciente, não apenas como espaço outro, heterogêneo ao espaço da consciência, mas considerado espaço psíquico fundamental" (BIRMAN, 2009, p. 42). O inconsciente psicanalítico não é o inconsciente fenomenológico de Jaspers, nem o filosófico de Schopenhouer. É, antes de tudo, um topos, lugar onde o psiquismo está centrado. É a outra cena, como quer Freud, onde se dá toda a sorte de relações do psiquismo humano, relações estas que o eu da consciência dá tão somente uma pálida ideia. Desta palidez, pode surgir uma pergunta que supõe um saber Outro, inconsciente, ponto de abertura e acesso ao sujeito barrado (\$). 
Nada há, portanto, em nossa vertente para situar Freud que se ordene pela astrologia judicatória da qual se impregna o psicólogo. Nada que provenha da qualidade e até do intensivo, nem de uma fenomenologia com a qual o idealismo possa reassegurar-se. No campo freudiano, apesar das palavras, a consciência é um traço tão caduco, para basear o inconsciente em sua negação (esse inconsciente data de São Tomás), quanto o afeto é incapaz de desenhar o papel do sujeito protopático, uma vez que esse é um cargo que não tem titular ali.

LACAN, 1998, p. 813.

Portanto, o significante só terá como efeito representar o sujeito para outro significante, como nos ensina Lacan, se antes houver - conforme demonstramos no capítulo sobre a constituição do sujeito - a ação do Outro subtraindo o gozo e inaugurando um sujeito dividido que pode, enfim, equivocar-se. Dito de outra forma, ter o inconsciente como sintoma da perda de gozo.

Em sua obra, Lacan não se serve da significação vulgar do termo gozo que, dentre outros sentidos, traz Houaiss (2004):

1. Ato de gozar, satisfação, prazer [...];

2. Estado que resulta da satisfação de uma atividade física, moral ou intelectual [...];

3. Posse ou uso de uma coisa [...];

4. Coisa engraçada divertida, graça [...];

5. Prazer sexual, orgasmo [...].

Braunstein (2007) destaca que a inspiração de Lacan vem da filosofia do direito, permitindo-nos apenas uma discreta aproximação com o sentido 3, recordado acima. O debate que Lacan faz a partir de seu contato com a filosofia de Hegel estabelece, de maneira central, a relação do sujeito com seu corpo e com o Outro. Vejamos esta álgebra.

Para possuir de fato seu corpo e dele gozar - ou seja, ter de pleno direito de usufruir do corpo e, então, acesso ao gozo -, o Outro do significante deve abdicar completamente deste corpo. Está estabelecida uma relação de apropriação e expropriação na relação sujeito/Outro, pois o corpo só o é quando tocado pelo significante, ou seja, conforme desenvolvemos anteriormente, o significante faz da carne corpo, e, ao fazê-lo, cria o sujeito do inconsciente. Ora, há um impeditivo lógico para o gozo (pleno)! Pois ele só seria possível com o abandono das intenções do Outro do significante sobre o corpo, o que reduziria este 
corpo à carne; caso preservemos o corpo, o gozo é perdido. Novamente estamos diante de um problema lógico: só podemos falar de corpo quando a carne é cortada pelo significante, com isso, estabelecemos uma visceral dependência do sujeito com o Outro. Lembremos que a definição de sujeito $\left(S_{1}-\$-S_{2}\right)$ envolve na sua álgebra o significante, ou seja, o Outro. É a relação de extimidade (intimidade e exterioridade), bem representada pela banda de Moebius, uma das figuras às quais Lacan recorre para demonstrar a topologia do inconsciente. Ora, temos então uma consequência lógica: o sujeito não pode gozar, pois para tanto o Outro deve abdicar de suas intenções (significante sobre a carne). O gozo só é possível com o retorno ao organismo, proposição que levou Lacan a entender a pulsão de morte como a verdadeira pulsão. Gozar plenamente só com o fim do sujeito e do corpo. É o Princípio de Nirvana apresentado por Freud no seu Além do princípio de prazer (FREUD, 1920), ou muito antes, quando concebeu um aparelho psíquico cuja missão seria reduzir a tensão ao mínimo, pelo Princípio da Homeostase.

Uma vez constituído, o sujeito, para ter acesso ao gozo na sua expressão mais pura, deve dedicar-se a uma paixão ao objeto perdido. Esta via-dolorosa, mortífera, conduzi-lo-á pelos áridos caminhos do desligamento do Outro e da consequente ruptura com o gozo-fálico. Este gozo já fora tocado pelos significantes, concluindo-se daí que já ocorrera uma perda de gozo. A lógica presente no gozo-fálico aproxima-se ao modelo da Carta 52, de onde se tira que há um resto que nunca entra no aparelho psíquico (gozo). A passagem da tradução/transcrição apresentada na referida Carta restringe a matéria inconsciente aos representantes pulsionais, não à pulsão propriamente dita, portanto, gozo-fálico.

Uma das manifestações clínicas mais eloquentes da referida ruptura com o gozofálico é a toxicomania. O sistemático recurso a um objeto externo ao corpo (que não é produto das formações do inconsciente), e que nele produz efeitos de retorno ao gozo-do-corpo (SANTIAGO, 2010), proporciona uma via de ruptura com o gozo-fálico e o consequente apagar do sujeito para o derradeiro encontro com o gozo e com o organismo (TEIXEIRA, 2006). O exemplo radical da especificidade da clínica das toxicomanias, com sua desmontagem do circuito pulsional, é a exceção que demonstra a regra. Outras formas mais atenuadas desta posição subjetiva apresentam-se nas patologias da identificação com o objeto, como proposto por Rabinovich (2004, p. 16): “O gozo fálico, que o constitui como medida comum para ambos os sexos, já é uma suplência dessa ausência estrutural que é o 'não há relação-proporção sexual”. 
O que está presente é a capacidade de usar e investir nas próteses como suplência da falta. Contudo, fazê-lo de modo a obturar a falta é travar a circulação do desejo, ao invés de relançá-la nas paixões do desencontro da satisfação (as necessidades podem ser satisfeitas, as pulsões, só parcialmente). Ou seja, o mortal do objeto é ser eficiente para tamponar a falta estrutural. O objeto perfeito torna a relação sexual possível: é o casamento sem falta, feliz, do bebedor com a garrafa (LECOUER, 1992). Este casamento perfeito leva à desarticulação da demanda e ao desregramento das pulsões. Rabinovich (2004) argumenta, com precisão, que o desenrolar das análises nestes casos é prejudicado não necessariamente pela gravidade psicopatológica dos mesmos (embora existam tipos graves), mas pelo mecanismo de gozo presente nestes sujeitos. São casos resistentes à análise justamente por estes sujeitos apagarem-se enquanto tal, enfraquecendo seus corpos e colocando o organismo em questão. Não há saber suposto no inconsciente e pouco a falar numa análise. O discurso médico apropria-se destes organismos, com sujeitos atenuados em sua potência. Cabe, portanto, à psicanálise, em uma boa direção do tratamento, implicar o sujeito no seu gozo, restituindolhes a função significante ao enfraquecer a identificação com o objeto. Ao fazê-lo, restitui-se o lugar de enigma do Outro e do sexo como trauma. Mas isso é outra discussão que não avançaremos aqui.

Em resumo, temos um problema estrutural: só é possível gozar do que é seu. Para se ter algo reconhecido como seu, o Outro deve abdicar do objeto em questão. Portanto, o gozo é barrado como condição de existência do sujeito. Para o gozo pleno não há sujeito, inconsciente ou corpo. Para o gozo pleno resta a carne, cruamente deserotizada. Como no mito de Narciso, figurado por Caravaggio (1597/98): gozar de si é morrer. Braunstein (2007, p. 17) resume o ponto de origem do conceito de gozo dizendo que o gozo "tem, pois, raiz hegeliana. Lacan lê Freud com uma faca afiada na pedra de Hegel”. Portanto, uma vez que é barrado de saída, o gozo passa a ser o problema central da psicanálise (por que não dizer no humano?), pois, como trataremos mais adiante, o inconsciente é sintoma do gozo. 
Devido a esta estrutural dependência do significante, o sujeito deve sua existência à ação do Outro sobre o organismo. O significante, portanto, coloca uma barra ao gozo e “organiza o modo de satisfação do corpo" (STRAUSS, 2010, p. 27). Na sua origem, o aparelho psíquico busca meios de satisfação reduzindo a tensão gerada pela demanda de trabalho psíquico originada pelas pulsões. É o Princípio de Prazer a buscar um equilíbrio homeostático virtualmente impossível, como descreve Rabinovich (2004, p. 15):

Por outro lado, a homeostase desse corpo, já atravessado pela linguagem, se chamará narcisismo. Portanto,o narcisismo surge, agora, com uma nova função: marca um ponto de homeostase, enquanto que na época do estádio do espelho, o narcisismo surgia como relação com Tânatos e como antihomeostático; mas essa é a diferença entre a perspectiva do organismo biológico e o corpo atravessado pelo sistema significante. No Seminário II, anti-homeostático era o processo primário, enquanto que no Seminário XI o anti-homeostático será a tyché em relação ao automaton, solidário do narcisismo. Que fique claro que esta é uma interpretação particular de Lacan do problema do narcisismo freudiano. Esta interpretação é coerente com a declaração explícita, que faz Lacan, no sentido de que toda a sua teoria sobre o gozo retoma a teoria energética freudiana e o problema da quantidade de energia em Freud.

A organização dos representantes pulsionais, conforme a teoria energética de Freud, sulca o aparelho psíquico, criando caminhos facilitados por onde passarão as descargas. São os trilhamentos pulsionais. Esta organização do corpo com relação ao Outro é produto do significante sobre a carne, portanto é o que podemos depreender da sexualidade, na sua equivalência com a libido, na leitura que Strauss (2010) faz de Freud. Portanto, há uma verdadeira submissão da satisfação possível à constituição singular do aparelho psíquico. $\mathrm{O}$ que equivale a dizer que cada um goza a seu modo e que o gozo não é de tudo domesticado pela ação do Outro.

A experiência de gozo que, como apresentamos anteriormente, em nada está obrigatoriamente vinculada ao prazer, dilui-se ao ganhar as representações. Assim, a satisfação corporal não é a satisfação do organismo (carne em si). É uma satisfação inseparável das representações, posto que é corpo. Por se tratar do efeito do significante, logo, do Outro, as excitações primárias são lugar mais de enigma do que de satisfação. Estas excitações são vividas como o incômodo aumento de tensão no aparelho psíquico. O 
Princípio de Prazer freudiano já rezava que o prazer era a experiência de baixar a tensão do aparelho psíquico. A constante pressão a qual o aparelho psíquico está submetido dá testemunho da desorganização e inquietude que o campo pulsional causa no sujeito. Quando submetido a uma ação específica que proporciona o rebaixamento do nível tensional, este sujeito é então levado não à experiência de satisfação, mas à captura pelo Outro. Estão abertos o campo do sujeito e o campo do Outro, no qual aquele deve situar-se nos enigmas da alienação e separação com o Este, de acordo com Strauss (2010, p.14):

Todos esses artigos de Freud sobre a vida sexual infantil, justamente consistem em nos mostrar como diante da excitação de seu corpo, da manifestação sexual do seu corpo, o sujeito não se contenta apenas, como um macaco, em satisfazê-lo, mas, ao contrário, o sujeito se interroga: o que é isso? Esse encontro com essa excitação tem mais um efeito de elaboração de saber do que de satisfação. A satisfação está mais ligada a esse elemento de saber do que à sua própria atividade física. Essa excitação física não é, logo de início, um prazer. Ela não vale por si mesma, é preciso toda uma construção que dará um significado a essa excitação, para que isso possa permitir ao sujeito encontrar essa satisfação.

Por isso a sexualidade é sempre traumática, dada sua relação com o gozo, o campo pulsional e o Outro do significante que, na sua ação específica, erotiza o corpo. Este sopro de vida é a ação do significante, que, no momento seguinte, falha. A primeira experiência é para sempre perdida. Ao dirigir-se ao Outro, espera-se algo dele que nunca será correspondido. Entra-se no campo pulsional quando um significante falha no campo do Outro, lançando o sujeito no enigma do seu desejo. Antes, tudo é uma massa disforme de aflições (desamparo original, nos termos freudianos). Isso levou Braustein (2007, p. 11) à tentação de modificar o Evangelho de São João:

Estaria tentado a começar com uma fórmula gnômica: Im Anfang war der Genuss (No princípio era o gozo), que, é claro, se contraporia ao começo do Evangelho de São João: Im Anfang was das Wort (No princípio era a palavra). 
Contudo, logo em seguida afirma que não o fará, não cairá em tentação, pois significante e gozo não se contradizem, muito antes pelo contrário, só há gozo no ser falante e só há palavra na relação com o gozo que limita (BRAUNSTEIN, 2007). Portanto, vamos avançar um pouco mais nas estruturas do significante e na sua articulação com o gozo.

\subsection{Entre o Simbólico e o Real}

Mesmo com todos os avanços teóricos e metodológicos sofridos pela psicanálise a partir das contribuições de Lacan, a regra de ouro não foi modificada. Muito antes pelo contrário! Lacan (1999) reconhece nos esquecimentos, atos falhos, chistes, lapsos e sintomas a mesma estrutura de linguagem. Preserva o método da associação livre, justamente por perceber que a determinação (o que deixa o termo livre um tanto impróprio) da associação de ideias dá-se pela via do significante, não do significado. O significante remete a outro significante, articulando no enodamento (ponto que Freud reconheceu como sobredeterminação do sintoma), as diversas cadeias de significantes. Não há um significado que esgote o sentido, não se trata disso. Portanto, com Lacan, a abstinência do analista fica muito mais radical. A interpretação psicanalítica opera afastando-se de quaisquer tentações que redundem em dar sentido, significado, ou outros significantes aos significantes apresentados pelo analisando. A interpretação psicanalítica aproxima-se do corte e do ato, justamente para alcançar algo fora da palavra. Para sermos lacanianos: Freud não explica.

O significante, portanto, não se define pelo significado, mas por outro significante que a ele faz oposição $\left(S_{1}-S_{2}\right)$. Este par já é suficiente para a constituição do universo simbólico (QUINET, 2003, p. 40). A descoberta do inconsciente revela as leis de seu funcionamento no exercício da associação livre durante uma análise. Lacan cria uma imagem de fácil assimilação para demonstrar a articulação das cadeias significantes. Desenha o inconsciente como um conjunto de cadeias significantes, dispostos como anéis, cujos pontos de articulação (sobredeterminação) são os significantes pertencentes a mais de uma cadeia. Esta característica de pertencer simultaneamente a mais de uma cadeia estrutura as formações do inconsciente e possibilita o método psicanalítico de tratamento. A característica 
fundamental de o inconsciente ser feito de equivocidade (significantes que deslocam de uma cadeia a outra) é ter a garantia da inexistência de um significante que o defina. Portanto, temos o sujeito do inconsciente dividido pelo significante, sem conseguir no significante sua significação. O significante apenas o representa. Por consequência, tiramos que a interpretação do inconsciente não é a explicação (significado), mas sim o desvelamento da posição do significante na cadeia associativa. Assim, temos no inconsciente a revelação de que o ser falante não só habita a linguagem como é habitado por ela. O inconsciente é um Outro que guarda com o sujeito uma peculiar relação de alteridade, pois não está nem fora nem dentro do sujeito. Não há barreira entre o que é do sujeito e do universo simbólico no qual está inserido.

Como falamos anteriormente, para Freud a pulsão é um conceito limite entre o psíquico e o somático. Portanto, não está propriamente em nenhum desses campos. A pulsão é representada no inconsciente pelos representantes pulsionais (Vorstellungrepresentanz), que, com Lacan, podemos chamar de significantes. De onde concluímos que são os representantes da pulsão que estruturam o inconsciente como uma linguagem. Ora, se adotarmos que o real é a energia pulsional, como nos propõe Quinet (2003, p. 47-48), “energia que se presentifica como satisfação pulsional ou gozo do sintoma", podemos dizer que pulsão é o conceito limite entre o simbólico (Outro) e o real (irrepresentável):

As pulsões são nossa mitologia, pois ao mitificarem o real produzem a relação do sujeito com o objeto perdido. Mitificação paradoxal, pois por um lado, lá onde está o sujeito não se encontra o objeto, ou seja, nas representações representativas da pulsão no inconsciente que indicam as demandas do sujeito ao Outro, e as demandas do Outro ao sujeito, modalizadas pela pulsão oral, anal etc... E, por outro lado, lá onde está o objeto da pulsão não se encontra o sujeito.

Os representantes pulsionais constituem o inconsciente, fazendo, então, recalque e inconsciente, conceitos correlatos e visceralmente imbricados. Precisamente por isso, recorremos no início deste trabalho à antropologia (o que aqui poderíamos chamar de nossa mitologia) para resgatar as origens do animal homem e nela assentar as marcas do recalque para o estabelecimento do inconsciente, da humanidade. $\mathrm{O}$ recalque sela o fim dos instintos e 
marca uma recusa lógica da pulsão habitar o inconsciente, legando ao inconsciente a fixação dos representantes pulsionais. A linguagem do inconsciente é a linguagem da pulsão. Temos assim que a psicanálise opera por meio da linguagem (simbólico) sobre o gozo (real) justamente por ser a pulsão o conceito que permite articular os registros do simbólico e do real. 


\section{O DESEJO, SEU MAL-ESTAR: UMA SAÍDA POSSÍVEL}

I can't get no satisfaction

I can't get no satisfaction

'Cause I try and I try and I try

I can't get no, I can't get no

The Rolling Stones

Ao longo deste trabalho, buscamos demonstrar que, a partir do ocaso dos instintos, perdemos a possibilidade de encontrar um objeto de satisfação. Ao perder o objeto para sempre, estabelecemos, desde o momento inaugural dessa perda fundadora, o desejo como condição estruturante e organizadora do sujeito. O sujeito se faz em razão do objeto perdido, objeto $a$, legando a satisfação plena à impossibilidade. O desejo é a derivada da impossibilidade lógica de complementaridade, e isso põe a máquina a andar.

O traço primeiro é a afetação do corpo na qualidade de fenômenos desconfortáveis. Esse traço se inscreve no corpo e nele se fixará, mutando-se "de uma fixação em ficção" (CHATELARD, 2005, p. 177). Na coleção dos traços, enredar-se-ão as novelas e os dramas pessoais, familiares, enfim, a vida das pessoas. Assim, conta-se a história dos sujeitos: passeando pelos significantes que o marcam ao longo de sua existência. O desejo é precisamente o vetor, a seta ( $\rightarrow$ ), que vai se deslocar de um significante $\left(S_{1}\right)$, representado nas origens pelo desconforto da necessidade num traço perceptivo, para outro significante $\left(S_{2}\right)$, representado pela traço do objeto que satisfaz. É o encontro da fome com o seio na mítica primeira mamada do bebê.

Deste modo, constitui-se a articulação de desejo e demanda. Segundo o modelo freudiano, a demanda é a reivindicação da restituição de um estado anterior de suposta completude. Suposta pelo sujeito inaugurado pela falta, pelo trauma de sua incompletude. A demanda é justamente a demanda de o sujeito não ser, pois ser sujeito implica em perda, em falta, em mal-estar, em desconforto de estar vivo. O desejo seria então a busca, pois ao articular sujeito e significante, algo fica "fora de significação, fora de sentido" (FILHO, 2008, p. 37). A trajetória que visa reencontrar o objeto perdido, não pela experiência, mas pela 
estrutura lógica da constituição do sujeito, é tida como desejo. Percebemos, então que o desejo tem a ver com movimento, portanto, aproxima-se ao que Freud entende por pulsão erótica. Quando falamos, então, de desejo, temos que o objeto referido na equação, por estrutura lógica, é objeto causa, inexistindo então o objeto do desejo.

Em contraste, quando falamos de necessidade, o acesso a um objeto não só é possível, como satisfaz. É o dar comida à fome, não ao sujeito que tem fome. É o estabelecimento da continuidade entre organismo e meio, cuja interação torna possível a extinção da vivência do desconforto. É o estado animal, manifesto em toda adaptação que os instintos proporcionam. Um animal encontra seus objetos no ambiente, no seu meio. A Mãenatureza provê. Como afirma Lacan $(1998$, p. 818,), “[...] o instinto, dentre outros modos de conhecimento que a natureza exige do ser vivo para que ele satisfaça suas necessidades, define-se como um conhecimento que é admirado por não poder ser um saber".

Como o bicho homem produziu próteses (ou seja, trabalhou para tanto e, neste engenho, há um saber) e com elas se relacionou de modo irreversível, modificando a si e à natureza, esta já não pode dar respostas às "necessidades" humanas, pois são de outra ordem, são outra coisa. A fala cria um universo simbólico que solapa a lógica da necessidade. A fome é fome do quê? O ser falante "não quer só comida". O ser falante não encontra seus objetos na natureza. Estabelecendo neste novo campo o trabalho como meio necessário de acesso ao que mata a fome, ao que rebaixa a tensão pulsional.

O efeito da fala é o radical descentramento do sujeito a partir da alteridade que o constitui. Portanto, o enunciado da fala do sujeito, ao contrário da ação do animal, não mira o objeto e sim ao Outro. Quando alguém fala a outrem, o faz por meio do código, ou seja, por meio do Outro, através do sistema significante disposto nesse Outro. Assim, aproxima-se a cadeia significante à demanda: toda fala seria, para Lacan, no extremo, uma demanda.

O desejo fica legado a um lugar de alteridade em relação ao sujeito, pois está no campo do Outro. Como vimos anteriormente, no estádio do espelho, o eu vê seu desejo no outro especular, portanto, num plano imaginário. Contudo, as coisas não se passam somente neste plano. O Outro da linguagem é de uma anterioridade lógica ao sujeito, fazendo do desejo algo determinado e mediado pela cadeia significante (simbólico) e causado pelo objeto perdido (objeto $a$. Real). Temos que o desejo é articulado através da demanda, aparecendo nos 
significantes. Assim, segundo as leis do inconsciente, de significante em significante percebemos o desejo se revelar como efeito do deslocamento da demanda.

Lembremos que o inconsciente é feito de representantes pulsionais recalcados, ou seja, pulsão erotizada, permitindo acesso ao gozo-fálico, "gozo na e pela linguagem" (DUNKER, 2002, p. 41). Percebemos que a pulsão, como uma demanda inconsciente que implica o corpo, uma vez que está entre o psíquico e o somático, gera demanda de trabalho ao aparelho psíquico. Então temos o desejo como alteridade ao sujeito e condição de possibilidade de o mesmo se destacar desse Outro. A pulsão, representada por $(\$ \diamond D)$, implica no apagar do sujeito da medida da tensão existente entre junção/disjunção com a demanda do Outro. Daí conclui-se que o pulsional é acéfalo (sem sujeito) e que o desejo pode ser uma saída do massacre do Outro.

Eis o ponto no qual podemos identificar uma das horas da verdade. Quando a demanda do Outro, manifesta na pulsão, constrange o sujeito, este deve buscar uma posição: ou desvanece, atendendo à demanda oferecendo-se como falo para gozo do Outro; ou sustenta uma posição de castrado, situando-se na dialética de ter/não ter o falo. Esta última posição, por ser tocada pela castração, é a articulação do desejo com a Lei. Portanto, o desejo é uma saída, que embora provoque mal-estar, possibilita barrar a demanda do Outro. É o vetor $(\$ \diamond D) \rightarrow[S(A)]$ que faz a passagem da demanda ao significante da falta do Outro.

Dunker (2002) ressalta que o ensino de Lacan percorreu em seu início a teoria do significante, privilegiando a interpretação linguística do inconsciente, passando pela subversão do sujeito para, finalmente, chegar à topologia das pulsões ao teorizar o objeto e seus paradoxos. Neste percurso, Lacan, de modo bastante consistente, opera no sentido de uma desbiologização dos conceitos freudianos, afastando a psicanálise de qualquer tentação fisicalista. O centro da argumentação está no campo da lógica no que toca o problema das pulsões demandando necessariamente a articulação com o gozo (real), como afirma Dunker (2002, p. 30):

A solução para o biologicismo fisicalista não está na proliferação de metáforas e analogias que tornem mais palatável uma certa metafísica da energia ou da experiência, mas em uma teoria sólida ou eficaz para o problema da diferença de valores psíquicos. Nossa hipótese de leitura é que a teoria do gozo em Lacan cumpre justamente esse papel. 
Logo, o conceito de pulsão, vital para a psicanálise, implica na sua articulação com o gozo. Conforme apresentamos anteriormente, o inconsciente é efeito da perda de gozo e sua missão é conferir valor psíquico a ele. Ou seja, os processos de transcrição, tradução e organização (associação dos significantes) realizados como trabalho psíquico no/pelo inconsciente, cujo esboço original está na Carta 52. A pulsão demanda trabalho psíquico, estabelecendo seu circuito a partir da perda traumática do objeto (castração) operada pela entrada na linguagem.

A partir dessa perda essencial, o objeto cai para o registro do real, deixando seu correlato não equivalente/complementar, o falo, a articular os outros dois registros. $\mathrm{O}$ falo assume o duplo papel de operador da perda de gozo e de ciframento/regulação de gozo. Quando imaginário $(-\varphi)$, opera o gozo possível por ser representante da falta e objeto imaginário da castração simbólica. Quando simbólico $(\Phi)$, estabelece a regulação e o ciframento do gozo que pode ser atingido, posto que é o símbolo da falta real.

Portanto, no lugar em que situa o desejo, Lacan destaca a irredutibilidade do mesmo à demanda, reivindicando um discurso ético - ética do desejo -, não psicológico, - centrado na existência de um objeto que atenda à demanda (LACAN, 1998, p. 819). Ora, se o sujeito é articulado pelo significante, onde situar o desejo? 
Na Subversão..., Lacan nos apresenta a montagem do grafo como uma resposta demonstrativa para a questão do desejo.

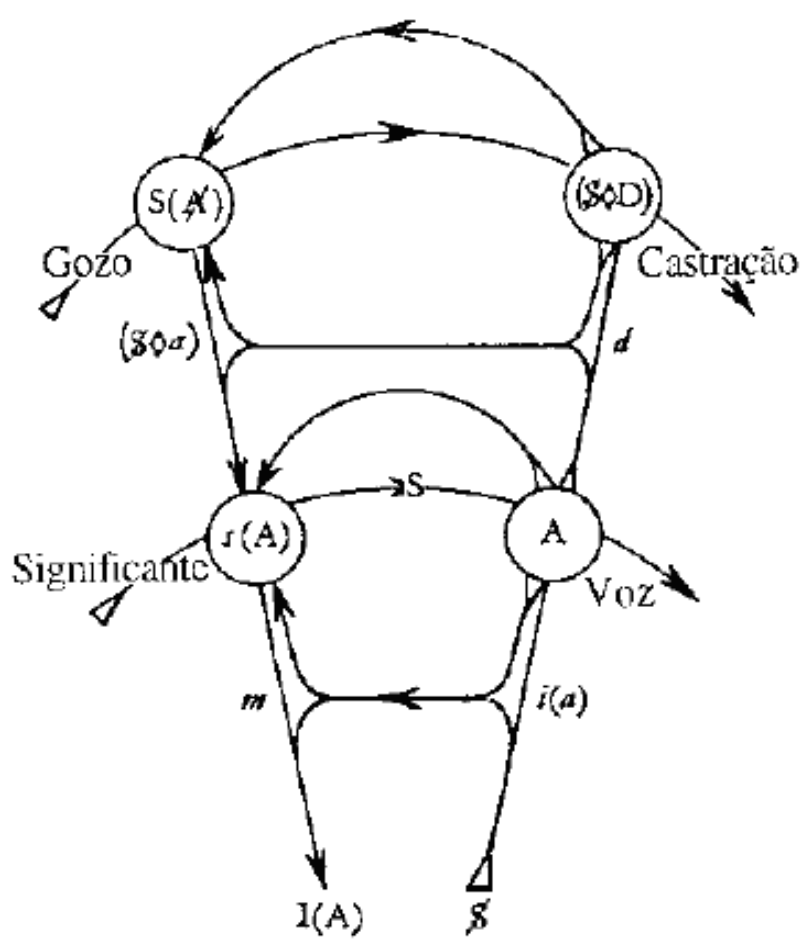

Lacan, 1998, p. 831

Caminhemos um pouco com ele. A célula elementar do grafo articula o significante que detém o perpétuo deslizamento da significação pelo ponto de basta. Ora, como a cadeia significante trafega de $\left(S \rightarrow S^{\prime}\right)$, o ponto de basta fecha a significação no seu último termo, por ação retroativa, numa função diacrônica. Portanto, temos o efeito da metonímia. Já a metáfora, estrutura sincrônica, é constituída como atribuição primária, que torna possível a passagem do signo ao significante. Nos pontos de contato, temos o (A) e o $s$ (A). No primeiro estão os significantes, dispostos em oposição uns aos outros, em um conjunto sincrônico e numerável. No segundo, lugar onde a significação se oferece. Atentemos ao destaque dado por Lacan (1998, p. 820): “Observe-se a dissimetria entre um, que é um local (mais lugar do que espaço), e o outro, que é um momento (mais escansão do que duração)". 
Tanto local como momento oferecem ao significante a constituição de furo, pois o circuito que se estabelece se fecha na própria escansão, ponto de basta, deixando algo fora da significação (FILHO, 2008). Deste modo, o sujeito está submetido ao significante no local e momento em que descompleta a cadeia significante constituindo-se como falta. O significante é o selo da onipotência do Outro, que aliena o sujeito na imagem de seu corpo em tudo aquilo que anteriormente apresentamos no estádio do espelho. É o berço que guardará para o semelhante (especular) sempre um toque de confronto e agressividade. Esse processo imaginário consolidará o caminho da subjetivação, por ação mesma do significante e reservará no palco das relações com o semelhante, as tensões do dia-a-dia. É o circuito desenvolvido por Lacan no andar inferior do grafo, cuja demonstração organiza as "funções relativas à imagem do ser e corresponde a gama de fenômenos em torno do eu que, apesar de sua vocação à unidade, não alcança a condição de autonomia que sua alienação faz crer viável” (FILHO, 2008, p. 39).

Observamos que as necessidades não dizem respeito, portanto, ao sujeito. A inapetência do filhote humano é pervertida pelo significante em demanda (Outro), na qual se supõe necessidades para superar a radical dependência do filhote. Assim, é a partir do desejo do Outro que o desejo do homem ganha sua forma. Lacan (1998, p. 828) destaca que:

O desejo se esboça na margem em que a demanda se rasga da necessidade: essa margem é a que a demanda, cujo apelo não pode ser incondicional senão em relação ao Outro, abre sobre a forma da possível falha que a necessidade pode aí introduzir, por não haver satisfação universal (o que é chamado de angústia). Margem que, embora sendo linear, deixa transparecer sua vertigem, por mais que essa seja coberta pelo pisoteio de elefante do capricho do Outro. É esse capricho, no entanto, que introduz o fantasma da Onipotência, não do sujeito, mas do Outro em que se instala sua demanda [...], e, justamente com esse fantasma, a necessidade de seu refreamento da Lei.

Temos que, assim como o eu é regulado, de certa forma, pela imagem do corpo, o desejo é regulado a partir da fantasia (LACAN, 1998, p. 831). A gramática da pulsão não se confunde, então, com a função orgânica que por ventura possa habitar na articulação da fonte com o objeto (ver circuito pulsional apresentado anteriormente), pois se o grafo situa a pulsão como tesouro dos significantes, a estrutura da fantasia liga-a a diacronia, justamente por 
derivação da demanda quando o sujeito desvanece. Estamos no andar superior do grafo, que representa o lugar do inconsciente. Neste andar, está incluso o que escapa às pretensões unitárias do eu, na sua mais radical experiência de articulação do desejo (d) com sua correlação com a fantasia ( $\$ \diamond$ a). É o cerne da experiência freudiana (FILHO, 2005).

Os dois andares do grafo demonstram que, na medida em que o Outro é solicitado a responder, temos a presença do significante da falta do Outro, $\mathrm{S}(\mathbb{A})$, operando. Portanto, quando é chamado a responder a partir do lugar na parte inferior do grafo, responder do lugar do $(A)$, responde a partir da cadeia superior, em termos da pulsão $(\$ \diamond D)$.

A castração permite a existência do falo como operador, cuja função possibilita, na dialética do desejo, dar corpo ao gozo. $\mathrm{O}$ falo, negativo enquanto imaginário $(-\varphi)$, assume enquanto simbólico $(\Phi)$ uma forma impossível de negativizar por ser significante do gozo. Uma vez que a Lei (castração) barra o acesso do sujeito ao gozo, pela marca mesmo do significante, o princípio do prazer, com suas ligações eróticas, estabelece no campo do desejo limites ao gozo (LACAN, 1998, p. 836).

Não por menos, Lacan percebe que o neurótico identifica a "falta do Outro com sua demanda, $\Phi$ com D" (LACAN, 1998, p. 838), reduzindo então a fantasia $(\$ \diamond a)$ à pulsão $(\$ \diamond$ D). Eis o ponto do sofrimento quando o sujeito vê-se capturado pela demanda do Outro. A articulação da castração com este gozo do Outro é que possibilita a assunção do desejo, justo nos termos da fantasia. Não desenvolveremos o tema, mas não podemos deixar de destacá-lo: esta articulação é, precisamente, o mapa da direção do tratamento. Ou seja, estamos no osso da discussão clínica.

Por fim, concluímos com Lacan (1998, p. 841) que a "castração significa que é preciso que o gozo seja recusado, para que se possa ser atingido na escala invertida da Lei do desejo". Sendo assim, o desejo é a defesa contra o transbordamento que levaria ao gozo. O desejo é a proibição e a garantia do limite no gozo. 


\section{UM SOPRO ILUMINISTA}

esta noite vai ter sol

Paulo Leminski

Buscamos ao longo deste trabalho demonstrar como a empreitada da humanização foi uma ruptura com a natureza. Nesta aventura, conhecemos o ocaso dos instintos e o nascedouro das pulsões. Este novo ordenamento, fruto da contaminação do organismo biológico pela linguagem, acarreta na existência do gozo como material propriamente humano. O inconsciente surgirá, então, como efeito, sintoma do tratamento do excesso natural de gozo ante as imposições da realidade por meio do aparelho de linguagem. O inconsciente é estruturado como uma linguagem, condição da linguagem e efeito da perda de gozo.

Sua realidade impõe uma condição de mal-estar insolúvel, permanente e persistente. Por isso, o circuito pulsional coloca em movimento as formações do inconsciente, como etapas decorrentes da modificação do gozo em seu tratamento pelo aparelho psíquico, no processo de diluição através das representações. Lembremos que o aparelho psíquico lida com os representantes pulsionais, deixando o campo pulsional, propriamente dito, como acéfalo, sem sujeito. Daí as produções do inconsciente operarem como o calor que a máquina dissipa ao cumprir seu trabalho. Caso o sistema esteja ajustado de maneira conveniente, em boas condições, seja lá o que isso for, a perda de energia em forma de calor não chega a comprometer o funcionamento da máquina. Contudo, de qualquer maneira, há o desgaste natural desta e não podemos contar com um ajuste perenemente adequado. Pelas próprias características do circuito pulsional, podemos afirmar com tranquilidade que nenhum ser falante estará "curado" do inconsciente, que não existirá sistema ou sociedade que supere em termos absolutos o mal-estar inerente da pressão do ser vivo.

Observamos também a assunção do desejo como uma das válvulas reguladoras da interferência do gozo no ser vivo. O desejo dá ao gozo um limite/tratamento possível. Ante ao gozo, resta desejar. Mas o desejo porta justamente em seu seio o mal-estar das renúncias pulsionais. A solução é ela mesma aflitiva, pois coloca o pacto edípico, uma concessão forçosa à castração, à força do Outro, como condição de possibilidade de o arranjo ser 
sustentável. Sustentável, porém, sempre ameaçado, pressionado. Não fica lá no caritó. É a pressão que, por vezes, leva ao surto psicótico, ou a desestruturação da neurose. É na hora da verdade, momento no qual o sujeito deve responder do lugar que ocupa no desejo do Outro, que veremos se o sujeito consegue então sua sustentação, ou se, no seu sofrimento ou desajuste, abre um questionamento sobre esse mesmo Outro que o suporta e o faz sofrer.

Claramente percebemos que estão em jogo aqui elementos da constituição subjetiva, bem como elementos do laço social. Ou seja, estruturas de constituição e suporte do sujeito. Sabemos que, bem ou mal, os sujeitos, quando chamados a responder deste lugar, ou posicionam-se ou vacilam. É a tensão causada pelo atravessamento real na vida ordinária das pessoas. Goldenberg (2006) resume assim: “[...] toda psicologia individual é ao mesmo tempo psicologia social, pelo simples fato da presença inevitável do outro, que entra em cena como modelo, objeto ou adversário".

Temos, assim como na constituição do sujeito, elementos importantes a articular. $\mathrm{O}$ organismo nasce à deriva no Outro e sob os cuidados do outro. É cortado traumaticamente pela linguagem e, ao conceder forçosamente a ela, faz uma travessia para constituir-se como sujeito. Nesta travessia, limita o gozo e situa-se no enigma do Outro: O que quer ele de mim? O inconsciente é um efeito dessa operação. O aparelho psíquico desenvolve-se então como derivada da ação da linguagem (Outro) sobre o organismo, numa ação de natureza mais lógica do que cronológica. Portanto, não estamos estabelecendo uma anterioridade temporal de um sobre o outro, mas uma anterioridade lógica como figurado na banda de Moebius e na fartamente demonstrada topologia lacaniana (LAFONT, 1990). A íntima relação entre sujeito e Outro cria tensões, perdas, e mecanismos que levarão o organismo, agora elevado à dignidade de pessoa, à sua empresa pela vida. O desenvolvimento humano, conforme demonstramos anteriormente, dá-se por meio de uma profunda dependência do organismo com o Outro, com o campo social. Portanto, embora fonte inesgotável de sofrimento, o sujeito o é, e se salva do excesso mortífero do gozo, através do Outro. É o arco que vai do $(S)$ ao $(\$)$.

Valer-nos-emos aqui do Direito, uma vez que Freud já o sinalizara como um dos reguladores do mal-estar presente no campo social (FREUD, 1930 [1929]). Claro que esta opção revela a inspiração hegeliana do próprio conceito de gozo contida no pensamento lacaniano. Reale (1998, p. 59) afirma que o Direito é "a ordenação bilateral das relações sociais, na medida do bem comum". O bem comum seria, para este autor, a ordenação das 
ações de cada homem sem prejuízo do alheio. Tal harmonização pretende regular uma estrutura social na qual seja possível a participação e comunicação dos indivíduos e dos grupos. Alcança as coisas na sua justa relação com os homens, sendo a coação elemento externo - e não intrínseco à vida jurídica -, pois entende que, preservada a relação proporcional de homem para homem, preserva-se a sociedade; corrompendo esta proporção, corrompe-se a mesma sociedade (REALE, 1998, p. 60).

Assim como a ideia de Contrato Social (Hobbes, Locke, Rousseau) é cara ao direito e íntima às noções de organização Social, de Estado e Segurança Jurídica, temos o Contrato Edípico (PELLEGRINO, 1983) como pedra fundamental da constituição do sujeito na sua relação com o campo social. Ideias pautadas na noção de proporção e relação de homem para homem. À sedimentação de mecanismos psíquicos que já são fundados e fundantes na renúncia pulsional, assentam-se os valores do pacto social, cuja tônica recai sobre a proporção das relações e não na anulação das diferenças. Ou seja, o discurso enquanto laço social é político. Acompanhemos o que nos diz Goldenberg (2006, p. 27):

Freud não se ocupa do gozo (Genuss) senão do prazer (Lust), mas trata ambos como sinônimos. Lacan trata-os como antônimos, e faz do primeiro um elemento-mor da teoria, depois de ter procurado o conceito no direito, mas precisamente na filosofia de Hegel. É o filósofo, não o psicanalista, que opõe desejo ao gozo. O desejo resulta, de fato, do reconhecimento recíproco e é universal, enquanto o gozo é pessoal (ele diz "subjetivo"), intransferível (ele diz "particular") e não pode ser compartilhado. Hegel prefere o universal ao particular, que tem valor apenas para o indivíduo e mais ninguém.

Privilegia, portanto, o desejo ao gozo que, a princípio, não precisa do outro. Deixemos a filosofia alemã e voltemos para a psicanálise francesa: gozar contraria o laço social definido pelo contrato, o acordo e a partilha. $\mathrm{O}$ direito, contudo, leva em consideração o gozo particular, exclusivo. Não há outro. A ilusão de forma coletiva de gozar (de cuja promessa algumas seitas fazem seu agosto) é apenas isso, uma ilusão, já que casa um dos membros gozo no seu corpo, isolado do resto (e a relação sexual não foge a esta regra: precisamos do parceiro para sustentar o desejo, mas o gozo em si é de cada qual $[\ldots])$.

Conforme acompanhamos, o desenvolvimento da Humanidade deu-se com o incremento de uma nova função psíquica a partir de condições desenhadas pela seleção natural. O efeito da evolução foi o descolamento da Mãe-Natureza como ditante da evolução e 
a adoção das Leis, da seleção-cultural, por assim dizer, como meio de desenvolvimento e organização. Forçosamente, portamos a condição de carregar um corpo pré-histórico e fazê-lo caber em hábitos modernos. Isso necessariamente pressiona para o incremento de doenças e sofrimento, a despeito de ser uma saída irreversível na corrida evolutiva. Saída custosa, mas que não abriremos mão precisamente pelas enormes vantagens que oferece na escala evolutiva das espécies. Não por menos, Freud (1930 [1929]) recorre à alegoria schopenhaueriana dos porcos-espinho na neve: ficar perto demais uns dos outros, incomoda; longe demais, incomoda também.

Os mecanismos psíquicos na sua interação com o campo do Outro, o Campo Social, são o veneno-remédio - pegando emprestado o termo que Wisnik (2008) usou para estabelecer a profunda intimidade, contradição e participação do futebol na formação social e na constituição do imaginário do povo brasileiro -, em uma explícita referência ao Phármakon, exercem operações constitutivas de recalque, defesa e outras formações para possibilitar e consolidar modos de laço social.

No artigo de 1913, Totem e tabu, Freud resgata um ponto importante da teoria de Darwin sobre os agrupamentos humanos para estabelecer, a partir da psicanálise, uma leitura original das bases da civilização como tratamento do gozo. Darwin estabeleceu sua perspectiva a partir da observação do comportamento sexual e social dos grandes símios, para logo em seguida transpô-los para o homem primitivo, no contínuo da linha evolutiva das espécies. Freud (1913, p. 145) nos diz:

Naturalmente, não há lugar para os primórdios do totemismo na horda primeva de Darwin. Tudo o que aí encontramos é um pai violento e ciumento que guarda todas as fêmeas para si próprio e expulsa os filhos à medida que crescem.

[...] Certo dia, os irmãos que tinham sido expulsos retornaram juntos, mataram e devoraram o pai, colocando assim um fim à horda patriarcal. Unidos, tiveram a coragem de fazê-lo e foram bem sucedidos no que lhes teria sido impossível fazer individualmente. (Algum avanço cultural, talvez o domínio de uma nova arma, proporcionou-lhes um senso de força superior). Selvagens canibais como eram, não é preciso dizer que não apenas matavam, mas também devoravam a vítima. $\mathrm{O}$ violento pai primevo fora sem dúvida o temível e invejado modelo de cada um do grupo de irmãos: e, pelo ato de devorá-lo, realizavam a identificação com ele, cada um deles adquirindo uma parte de sua força. A refeição totêmica, que é talvez o mais antigo festival da humanidade, seria assim uma repetição, e uma comemoração desse ato memorável e criminoso, que foi o começo de tantas coisas: da organização social, das restrições morais e da religião. 
É interessante observar que Freud sugere a organização coordenada (armas) e o desenvolvimento de uma prótese (instrumento arma) para mudar o arranjo da horda primitiva. Destacamos, portanto, o valor da união entre os, por assim dizer, castrados - referência que iguala e identifica os irmãos - e da renúncia em estabelecer novamente um gozador de todas as fêmeas para o ajuntado de irmãos converter-se num clã parricida. Eis o ponto da harmonização proporcional entre os homens como finalidade do Direito e da exterioridade da coação neste pacto. A renúncia ao gozo e a admissão de uma perda essencial do mesmo, por estrutura lógica não experiencial, possibilita o laço social. Justamente aqui ocorre o enlace lógico do pacto edípico (castração e renúncia ao gozo) e do pacto social (regulação e adesão às Leis). Portanto temos a horda primeva (gozo) como anterior ao totemismo (organização, Lei, cultura). Foi assim no mito estruturante da horda primeva e das sociedades totêmicas: Mata-se o Pai primevo, terrível e gozador, aquele que tudo podia, para viver sem tudo poder, mas com acesso a alguma forma de gozo. Um gozo parcial acessível a todos, mesmo, e justamente, regulado pela Lei (gozo fálico). A incorporação do pai, comendo-lhe a carne, assimilando sua força, é a rendição de uma homenagem ao pai morto, edificado pelo seu nome: Nome do totem, da tribo, da família, da Lei.

Esta comunidade estabeleceu seu pacto social renunciando à vingança e glorificando o pai morto, agora despersonalizado e incorporado, na adesão à Lei. Esta operação foi possível em decorrência do pacto edípico, cujo mandamento é sustentado pela frustração traumática e pelo banho de sangue que fez do Pai primevo um nome, uma Lei. Com isso, Freud chega mesmo a afirmar que o "sistema totêmico foi, por assim dizer, um pacto com o pai” (FREUD, 1913, p.148). Portanto, as instituições humanas estão na base e na própria condição de possibilidade de tratar o gozo e evitar a revindicação do lugar de gozo pleno do pai da horda. O pacto social, ou seja, a lei, regula as relações entre os irmãos, legando a força paterna às instituições sem, contudo, cometer o equívoco de "supor que os impulsos hostis inerentes ao complexo-pai foram completamente silenciados durante esse período de autoridade paterna revivida" (FREUD, 1913, p. 153).

A civilização é feita a partir da renúncia pulsional, portanto, o mal-estar decorrente dessa renúncia é o mal-estar dos laços sociais. Lacan organiza o mal-estar na figura dos discursos, pois discursos são modalidades do laço social estruturados pela linguagem. Assim, podemos assumir que o laço social é uma forma de aparelhar o gozo e estabelecer relações entre as pessoas. 
Foi assim no desenvolvimento da constituição subjetiva. A renúncia à plena satisfação pulsional abriu caminho para a civilização. A organização subjetiva e o laço social estão assentados na renúncia de gozo e na estruturação de um pacto com o Outro, que produz efeitos reguladores nos outros, cuja entrada deu-se pela via do trauma, da ruptura com o estado de possibilidade de gozo. Assim, desejo "e gozo formam uma antinomia ética cujo mediador encontra-se na ideia de lei” (DUNKER, 2002, p. 49).

Portanto, é licito arriscarmos um olhar virado ao futuro, uma vez que fomos tão longe no passado para chegar ao ponto em que estamos agora. Ora, parece fundamental avançarmos nossa reflexão sobre os componentes da articulação entre uma sociedade, uma vez que optamos irreversivelmente por viver nela, e uma ética do desejo suportada nesta mesma sociedade. O modelo freudiano nos permite pensar numa ética do amor e trabalho, articulando o campo pessoal (amor, em suas mais diversas expressões) com o social (trabalho na qualidade de produto inclusivo no discurso). Esta mirada busca lançar um raio de luz na direção das instituições, pois não se trata de ficarmos pensando sempre num Pai melhor, ou noutra Lei, seja simbólica ou do legislador. Pensamos que o trabalho ora desenvolvido pode nos ajudar, não só a analisar, mas também contribuir, à pergunta: o que faz uma sociedade melhor do que outras (numa ética compatível com o que chamamos em psicanálise, a partir de Lacan, de Ética do Desejo)? O desenvolvimento e regulação das sociedades, manifestado através de suas instituições, não seriam os meios de viabilizar destinos pulsionais, manifestos na direção do amor e trabalho?

O laço social é uma das saídas para equilibrar a cara fatura das renúncias pulsionais. Revindicar um retorno mítico ao estado de plena satisfação é o fatal retorno ao organismo, com o seu correlato desenlace do Outro (ruptura e/ou recusa da castração). No sentido pessoal, é a desmontagem do sujeito através da ruptura com o gozo-fálico, cujo efeito é mortífero. No campo social, é o esgarçamento do tecido social com a precarização das instituições e a decorrente desimplicação do sujeito com o coletivo em atos comparáveis à perversão ou à loucura. No sentido pessoal, o sujeito desfaz-se, deixando seu corpo como rebotalho (TEIXEIRA, 2006). No sentido social, os pequenos grupos isolam-se por ter o Outro do social, nas figuras dos outros, como ameaças ou objetos de exploração (DUNKER, 2015). É a corrupção do homem e da sociedade denunciada por Reale (1998). 
Desfeitos laço social e contrato edípico, nada resta, nem sujeito, tampouco Outro. Goldenberg (2006, p. 38) afirma que as "culturas se diferenciam conforme o modo de administrarem o gozo". Daí tirarmos que uma sociedade parece cumprir melhor sua missão civilizatória quando permite uma cota de satisfação pulsional (lembremos que cada um goza a seu modo) num equilíbrio suficiente para não desejarmos todos, e cada um por si, a quebra ou corrupção do pacto social, justamente por este ser fiador do pacto edípico numa dimensão de bom arranjo. O desejo no humano é a saída do gozo. Desejar é viver na polis, pois o desejo passa necessariamente pelos nomes do Outro, o que faz do bicho-homem algo mais do que um animal social, como os símios, nos faz animais políticos. Na medida em que desejo não é realização de desejo, resta sempre um ponto de gozo, um tanto de mal-estar insolúvel com o qual cada um deve haver-se na sua hora da verdade. Este momento pode apontar para o enfraquecimento do pacto edípico e social ou para implicação do sujeito com os campos do amor e trabalho.

A mirar o campo social, temos então que uma sociedade é tanto melhor quando consegue instituições suficientemente fortes para inibir e/ou impossibilitar a assunção da realização de determinados impulsos. Como foi possível estabelecer a íntima relação entre sujeito e Outro, podemos nos espelhar no que se pensa para um sujeito para prospectarmos o que é desejado para o campo social (ou seja, arranjo dos próprios sujeitos na lida ordinária com o outro). Sigamos com Goldenberg (2006, p. 23):

O que esperamos de um tratamento psicanalítico é que seja o próprio paciente a avaliar a qualidade e o tamanho da sua repugnância e a tomar a si a responsabilidade pelo que dela decorre. [...] Não existe qualquer terapia, mesmo de um autista ou de um psicótico, sem o reconhecimento por parte do doente de uma decisão no cerne de sua doença.

O arranjo que parece ser o melhor para o campo social (pois, conforme já apresentamos, o que diferencia as sociedades parece ser o modo no qual elas modulam as formas de renúncia ao gozo, por meio da estreita relação do pacto social com o pacto edípico) é aquele no qual os sujeitos sentem-se amparados e implicados na renúncia do gozo, parcialmente satisfeitos com a realização possível e intolerantes com a ameaça ao pacto social (Lei, nome do pai morto), deixando uma via possível de satisfação pulsional pelo trabalho (no 
campo social) e do amor (no campo pessoal). A despersonalização diminui o aspecto especular, íntimo à agressividade imaginária, e aproxima-se às renúncias pulsionais. Portanto, boas instituições preservam os irmãos do desejo de cada um deles revindicar para si o lugar de gozador.

\begin{abstract}
Os desejos sexuais não unem os homens, mas os dividem. Embora os irmãos se tivessem reunido em grupo para derrotar o pai, todos eram rivais um dos outros em relação às mulheres. Cada um queria, como o pai, ter todas as mulheres para si. A nova organização terminaria em uma luta de todos contra todos, pois nenhum deles tinha força tão predominante a ponto de ser capaz de assumir o lugar do pai com êxito. Assim, os irmãos não tiveram outra alternativa, se queriam viver juntos - talvez somente depois de terem passado muitas crises perigosas -, do que instituir uma lei contra o incesto, pela qual todos, de igual modo, renunciavam às mulheres que desejavam e que tinham sido o motivo principal de se livrarem do pai. Dessa maneira, salvaram a organização que os tornara fortes - e que pode ter-se baseado em sentimentos e atos homossexuais, originados talvez durante o período de expulsão da horda.
\end{abstract}

FREUD, 1913, p. 147.

Admitindo, como quer Quinet (2006), que todo laço social é um enquadramento da pulsão, resultando uma perda real de gozo, podemos suspeitar que a inclinação natural do homem é abusar sexualmente, torturar, matar seu "irmão", na tentativa de saciar a pressão da sua pulsão de morte erotizada.

Talvez nada mais claro do que recorrer ao exemplo da violência e da morte para pensarmos o valor da renúncia pulsional e das instituições, justamente por serem violência e morte efeitos últimos da desagregação do laço social e da relação sujeito/Outro. Também podemos revindicar que o mito fundador da sociedade é um conto de sangue e morte. Fomos fundados a partir da violência e da contenção desta mesma violência. Portanto, a sociedade não precisa idealizar-se na ilusão que seus membros não desejem se matar mutuamente. Tão pouco conseguiria tal empresa. Chamemos ao nosso auxílio a provocante argumentação de Pinker (2013) no seu Anjos Bons da Nossa Natureza - por que a violência diminuiu. Neste estudo, o autor apresenta, de maneira bastante convincente, com forte base estatística e olhar histórico, que a violência está caindo em termos absolutos, a despeito da intuição de que ela está aumentando conforme aumenta o adensamento humano. Pinker (2013) destaca que, 
justamente em razão desse adensamento, certas expressões da violência foram ao longo do tempo ficando intoleráveis no campo social. A sensação e o mal-estar que sentimos, revelado na crença irracional de que a violência está aumentado, é sintoma de que há menos espaço no próprio campo social para o exercício da violência. Com isso, os canais de mediação, organização, punição e controle foram se fortalecendo na medida em que os arranjos sociais ficaram mais estáveis e confiáveis. Observa-se uma transição da vingança para a punição cada vez mais despersonalizada. Podemos, sem forçar o argumento, afirmar que deixar a violência legada ao intolerável, num arranjo conservador do pacto social, em nada implica em deixá-la menos desejada inconscientemente. O desejo violento nunca será banido. Podemos nos satisfazer com arranjos no campo social que não desenlacem os discursos, com arranjos que permitam satisfações substitutivas, marcadas e reguladas pela própria cultura (como os esportes, sangrentos ou não, por exemplo. E a solicitação da via da Sublimação como um dos destinos pulsionais). O próprio Freud (1913, p. 153) afirma que "seria um equívoco supor que os impulsos hostis inerentes ao complexo-pai foram completamente silenciados durante o período de autoridade paterna revivida". Os meios de satisfação mediados, ou seja, tocados pela Lei, pelo Outro, nessa autoridade revivida, estão tanto mais finos quanto melhor for o arranjo do pacto social. Portanto, temos que o Outro estrutura o sujeito e que a implicação deste com o campo social produz uma estabilidade, cuja base é a renúncia, mais estável e melhor.

Uma sociedade que fracassa menos - pois todo arranjo é uma forma de fracasso, o que não quer dizer que seja ruim - na sua missão civilizatória deve buscar instituições (por serem despersonalizadas, diminuindo a agressividade imaginária) que exerçam bons e eficientes inibidores e que possibilitem caminhos razoáveis de satisfação substitutiva, ou seja, meios do sujeito estar implicado com seu desejo num arranjo conservador do campo social.

Conforme apresentamos, em nossa escalada evolutiva, os homens primitivos organizavam-se em pequenos clãs familiares. O assassinato de outro humano de outro clã era aceitável e esporádico, pois a exposição era relativamente pequena. Contudo, com o adensamento populacional e o aumento da eficiência/letalidade das armas (próteses), com a sistemática organização em armas (componentes de um exército), culturalmente fomos desenvolvendo instituições que deixam o assassinato em específico, e a violência no genérico, cada vez menos aceitáveis. O mal-estar decorrente do contato com os outros deve buscar saídas possíveis sem o esgarçamento do campo social ou da subjetividade na forma das 
patologias ou do sofrimento. Com a solidificação destas instituições, o desejo de matar tem a repressão de sua expressão "garantida", no que o Outro pode oferecer de garantia. Os deslocamentos e satisfações substitutivas serão requisitadas para socorrer o desejante frustrado, daí decorre o trabalho como saída possível. Por óbvio, quando o arranjo social é satisfatório, não aniquilamos os impulsos, mas os deixamos recalcados, reprimidos ou sublimados, conforme quer Freud nas Pulsões e seus destinos (FREUD, 1912). Ou seja, os destinos da pulsão caminham em seus trilhos conquistando alguma forma de satisfação mais conservadora do laço social, mesmo que para isso os sujeitos arquem com um custo subjetivo.

Cada um goza a seu modo, mas o gozo regulado pelo Outro segue um dos caminhos da satisfação pulsional. São caminhos mediados pelos representantes pulsionais, portanto diluídos. Um tigre não perde suas listras, mas o Campo do Outro estabelece, de certa forma, os caminhos legítimos que a satisfação pulsional percorrerá. A conta será dividida entre todos, no sofrimento da existência, com sua particularidade e sintomas e com o campo social, cuja organização imporá uma cota de insatisfação e mal-estar a todos. Como visto anteriormente, os trilhamentos pulsionais são caminhos possíveis, dada a perda de gozo e a assunção do desejo. Estas vias são marcas do Outro. Portanto, não por menos, Freud nos deixou a pista de que a felicidade (no que seria, então, uma ética do desejo, não pura e simplesmente a ética do bem comum) é a pessoa conseguir amar e trabalhar. Ou seja, desejar num arranjo que seja, ao mesmo tempo, conservador do sujeito e do Outro. É mantermos o tigre constantemente alimentado, sem esquecer que é um tigre.

Quando as instituições enfraquecem, o pacto social afrouxa. Assim, o nível de pressão sobre o sujeito aumenta, demandando formas mais diretas, menos mediadas pela cultura, de satisfação. É a desorganização do campo pulsional penetrando na organização do sujeito e do Outro. Temos uma aproximação com a barbárie das satisfações diretas, com os excessos que colocam o corpo em evidencia ou com o gueto que fortalece a máxima sartriana de que o inferno são os outros. Bárbaros são sempre os estrangeiros, os outros.

Com o enfraquecimento da implicação subjetiva no discurso, aumentam os efeitos da identidade coletiva, ou seja, ocorre um enfraquecimento do Outro e um retorno ao narcisismo das pequenas diferenças (FREUD, 1921). Esta lógica empurra ao condomínio, no sentido do social, e ao sintoma, no particular. Dunker (2015) afirma que a lógica do condomínio tem por premissa a exclusão do que está "fora do muro", dos limites que separam os outros, criando o 
efeito de alienação da tensão desse lugar cercado com seu exterior, articulando, então, três momentos da fantasia e um do sintoma no processo denominado condominização. O destaque dado a isso que podemos ilustrar como mau arranjo, ou fracasso do campo social, implica na insuficiência do sintoma em apresentar angústia e no recurso à fantasia e exclusão do outro como solução de fantasia para o sofrimento da ameaça dos povos bárbaros (DUNKER, 2015, p. 55).

Na proposição de Dunker (2015, p. 56) sobre o processo de condominização, temos o primeiro tempo da fantasia situado no momento anterior da experiência da divisão do sujeito e da esquize do olhar, momento desenvolvido anteriormente no capítulo que trata do estádio do espelho, desenhando um mal-estar real. O segundo tempo é marcado pela nomeação do mal. Seu recalcamento simbólico leva à perda da unidade (suposta) e à lógica da segregação. Ocorre o desenvolvimento das identidades narcísicas e dos muros da segregação. É toda a alegoria cantada pelo Pink Floyd na ópera-rock The Wall ou na vivência desorganizadora dos rolezinhos. Já o terceiro tempo é marcado pela consolidação imaginária da potência da autoridade paterna (simbólica). É um pacto sintomático, por assim dizer, cuja manutenção depende da assunção da impostura da força de autoridade simbólica. Esta impostura flerta com a perversão, na qual o objeto divide o sujeito na inversão mesma do matema da fantasia $(a \diamond \$)$. O mal-estar é experienciado, não como condição inescapável do pacto edípico e social, mas como uma inobservância da norma. É a pretensão do total controle social das normas e condutas que caminham no sentido de uma biopolítica, como quer Foucault (2008). Temos então a tensão rumo aos modelos das instituições totais (GOFFMAN, 1999) ou ao panóptico de Benthan, configurando uma báscula entre a paranoia do tudo ver e a perversão da regra desproporcional. Este é o ponto no qual Dunker situa a lógica do condomínio e que, aqui, estamos propondo como mau arranjo ou fracasso. Estabelecer o ponto central do discurso (laço social) nesta lógica seria estabelecer uma comunidade de crentes. Crentes na existência de uma Lei plena, perfeita e que o mal-estar é contingente da desordem provocada pelo vizinho, e não um efeito necessário do pacto edípico no seu enlace com o pacto social. Por fim, em decorrência mesmo do fracasso e da solução imprópria do condomínio, temos as formações de sintomas com seu excesso de gozo (DUNKER, 2015, p. 57): a violência, o medo e tudo o mais que a comunidade busca deixar fora do muro.

É, justamente, na tentativa de sair do mal-estar através dos atalhos que driblam o Outro dos arranjos contratuais insatisfatórios, que se acaba por aumentá-lo, o mal-estar, na 
precisa anulação da diferença. É a frustrada tentativa do significante $\left(\mathrm{S}_{1}\right)$ que busca ser igual a si. Anula-se numa mesma ação sujeito e Outro. A carga só pode alcançar o outro, representante encarnado do Outro terrível e gozador, em ações que hostilizam o outro ou desagregam o arranjo do pacto social. Ao tomar o "semelhante, com sua presença e seus quereres, obstaculiza a consecução do meu gozo, obstáculo que desperta a agressividade que deve ser refreada mediante a lei, esta vista como uma figura do poder repressor do outro sobre meus desejos" (GOLDENBERG, 2006, p. 28).

Temos a expressão patológica, na medida em que entendemos o patológico como a desorganização deletéria do funcionamento, seja psíquico ou social, do arranjo que fracassa ao desarticular a demanda. No capítulo anterior, tratamos da articulação do desejo com a demanda como ponto de estofo para limitar o desregramento do gozo. Assim, temos a demanda mais próxima ao excesso de desejo e o sofrimento ao excesso de mal-estar (DUNKER, 2015, p. 59). Aqui temos um ponto de inflexão. O mal-estar é onipresente. Contudo, a depender do arranjo, os sujeitos em questão lidaram com o mal-estar do desejo, ou com o mal-estar do sofrimento (gozo). Por óbvio, não cremos nem queremos uma Passárgada, mas uma equação cujas duas formas de mal-estar coexistam. A discussão é sobre prevalência de uma sobre a outra e da calibragem da proporção em que se apresentam.

Temos uma leitura que permite aproximar os dois momentos do pensamento lacaniano, a saber: estrutura e discurso. O pensamento estruturalista (universalista) avançou na concepção da relação do sujeito com o Outro, muito para além da ideia de doença, na demonstração das formas sintomáticas de manifestação ou fantasmáticas, a partir da posição em relação ao significante Nome-do-Pai. O conceito de gozo leva necessariamente a uma nova organização teórica fundada na negatividade representacional (ontológica), destacando o discurso como laço social na articulação lógica do sintoma e sofrimento. Dunker (2015, p. 106) nos diz então que:

O condomínio expressa uma espécie de nova montagem entre supereu e fantasia, uma nova política de manejo da alteridade e do antagonismo social, em cujo epicentro podemos colocar o mal-estar na a-violência. Os novos sintomas ganham assim, uma espécie de princípio de redescrição, a partir do qual são dispostos tanto como efeito articulados de uma nova forma de declínio da função social da imago paterna quanto de uma irrupção do Real, reunindo assim as duas estratégias concorrentes em psicanálise [...]. 
Convocamos em nosso auxílio o romance de Chuck Palahniuk (1996) Clube da Luta. Com uma narrativa seca, niilista e frenética, escancara o enfraquecimento do Pai totêmico ou do mito da Lei como mantedores de certo gozo prometido. Os ideais e objeto de consumo são apresentados numa metonímia eterna, sem ponto de estofo, levando o herói a trabalhar horas a fio, comprando tudo que promete felicidade, sem a menor identificação com o trabalho ou com a satisfação dos objetos. Começa a viver num certo transe, provocado pela insônia. Este transe dilui a importância do que é mesmo real. Os pequenos pontos de consolo são nos grupos de apoio de misérias alheias às suas. Satisfazia-se na farsa. O ruído surge na presença de Marla, uma mulher, que sabe de sua mentira essencial. Ela, por sua simples presença, começa a interditar esta organização do gozo no campo social (grupos de apoio). O duplo, o outro, aparece na figura de Tyler. $\mathrm{O}$ arranjo de estabilidade estava se precarizando até tudo ir para os ares numa explosão. O herói passou a viver só com o essencial e criou com Tyler um clube em que, a perda de potência dos referenciais fálicos, os gadgets e o gozo do consumo, não são mais perseguidos. O clube da luta, cujos fundadores são homens criados por mulheres, com empregos medíocres, fixado no consumo de bens que não precisam, esgarça o laço social pelo exercício da violência: "Talvez não precisássemos de um pai para sermos completos. Não tem nada de pessoal em quem você enfrenta no clube da luta. Você luta por lutar. Você não deve falar do clube da luta, mas nós falamos (...)” (PALAHNIUK, 1996, p. 63). E com os dejetos do corpo (gordura) utilizado para o marco cultural (sabão) tudo vai aos ares, a começar pelos prédios do sistema financeiro. Nesse romance, vemos o desarranjo do discurso, uma leitura que unifica a estrutura esquizoparanóide como o desenlace com campo social na lógica extrema do condomínio. Um clube do qual ninguém pode falar, mas que o crescente número de frequentadores revela que não se cumpre a primeira regra do clube da luta: "não falar do clube da luta”. A violência revela-se como saída perante o arranjo fracassado.

Parece vital o avanço na articulação de um discurso da psicanálise como ética e implicada numa política. Se para o analista o ato traz toda uma nova dimensão na relação do sujeito com sua fantasia, a partir de uma clínica do real, a implicação do sujeito no discurso, no laço social é a política. 
As práticas política e psicanalítica (e, poderíamos acrescentar, a educacional) são exercícios retóricos, atos de fala. $\mathrm{O}$ uso da linguagem para ambos a finalidade de produzir uma mudança efetiva no interlocutor e o meio para isso é menos o sentido comunicado que o ato ilocucionário em si, a sua forma. Nem a interpretação é cognitiva (Freud não explica nada), nem a intervenção política é "constatativa" (referindo-se à alta dos juros, não exprime uma opinião, induz uma mudança no mercado); ambas são atos de fala com efeitos concretos sobre o destinatário. Não é necessária, portanto, uma fina análise para perceber que a oposição ingênua entre as posições do psicanalista e do político se sustenta.

GOLDENBERG, 2006, p. 56.

Por fim, como procuramos demonstrar, a longa jornada da humanização da espécie foi uma aventura de renúncia. A partir do trauma da linguagem, com a abertura do campo pulsional, este animal foi para sempre dividido. Perdeu o senhorio de sua casa, mas ganhou inteligência. O caminho do desenvolvimento cultural é produto e produtor desta contínua afetação, que estabelece nos laços sociais modos de tratamento do excesso de gozo. Os arranjos são sempre fracassados, pois não há cura do inconsciente, mas existem arranjos melhores que outros. As culturas conseguiram ordenar o impulso predatório estabelecendo Leis cujas representações são institucionais. É justamente nestas instituições que estão depositadas as possibilidades de calibrar a eterna tensão entre o certo prejuízo da renúncia de gozo e a satisfação pulsional possível. Para o analista, o ato. Para o cidadão, a política. 


\section{Bibliografia Utilizada}

ARRIVÉ, M. Linguagem e psicanálise, linguística e inconsciente - Freud, Saussure, Pichon, Lacan. Jorge Zahar Editor; Rio de Janeiro; Brasil; 1999.

BADIOU, Alan. Não há relação sexual: duas lições sobre "O aturdito” de Lacan. Editora Zahar, Rio de Janeiro, Brasil, 2013.

BIRMAN, Joel. As pulsões e seus destinos: do corpo ao psíquico. Editora Civilização Brasileira, Rio de Janeiro, Brasil, 2009.

BOURGUIGNON A. História Natural do Homem v. 1 -O homem imprevisto. Jorge Zahar Editor, Rio de Janeiro, Brasil, 1990.

BRAUNSTEIN, N. Gozo. Editora Escuta, São Paulo, Brasil, 2007.

BRIVTO, L. A influência de Darwin sobre Freud - Um conto de duas ciências, Imago Editora, Rio de Janeiro, Brasil, 1992.

BREUER, J.; FREUD, S. Estudos sobre a histeria (1893 -1895); in.: Edição Standard Brasileira das Obras Psicológicas Completas de Sigmund Freud, Editora Imago, Rio de Janeiro, 1980.

CHATELARD, D. Da pulsão escópica ao olhar: um percurso, uma esquize; Editora Imago, Rio de Janeiro, 1995.

O conceito de objeto na psicanálise - do fenômeno à escrita; Editora Universidade de Brasília, Brasília, Brasil, 2005

COUTINHO JORGE, M. A. Fundamentos da Psicanálise de Freud e Lacan, vol.1 - As bases conceituais. Jorge Zahar Editor, Rio de Janeiro, Brasil, 2000.

DARWIN, C. A origem das Espécies. Editora Martin Claret, São Paulo, Brasil, 2007.

Brasil, 2004.

. A origem do homem e a seleção sexual. Editora Itatiaia, Belo Horizonte,

DAWKINS, R. The extended phenotype - the long reach the gene. Oxford University Press, Oxford, New York, 1999.

A grande história da evolução - na trilha dos nossos ancestrais. Editora

Companhia das Letras, São Paulo, Brasil, 2009.

DIAMOND, J. Colapso - como as sociedades escolhem o sucesso ou o fracasso. Editora Record, Rio de Janeiro, Brasil, 2005. 
. Armas, germes e aço - os destinos das sociedades humanas. Editora Record, Rio de Janeiro, Brasil, 2009.

. O terceiro chimpanzé - a evolução e o futuro do ser humano. Editora Record,

Rio de Janeiro, Brasil, 2010.

. Por qué es divertido El sexo? La evolución de la sexualidad humana. Debolsillo, Barcelona, España, 2013.

DUNKER, C. O cálculo neurotico do gozo. Editora Escuta, São Paulo, Brasil, 2002.

. Mal-estar, sofrimento e sintoma - uma psicopatologia do Brasil entre muros.

Editora Boitempo, São Paulo, Brasil, 2015.

FILHO, D. Psicanálise e medicina. Editora Escuta, São Paulo, Brasil, 2008.

FINK, B. The Lacanian Subject - Between Language and Jouissance, Princeton University Press, Chichester, West Sussex, United Satates of America, 1995.

FERNANDES, M. Corpo. Casa do Psicólogo, São Paulo, Brasil, 2003.

FOUCAULT, M. Nascimento da biopolítica. Editora Martins Fontes. São Paulo, Brasil, 2008.

FREUD, S. A interpretação das afasias, Edições 70, Lisboa, Portugual, 1977.

. Carta 52; in.: Edição Standard Brasileira das Obras Psicológicas Completas de Sigmund Freud, Editora Imago, Rio de Janeiro, 1980.

Carta 79; in.: Edição Standard Brasileira das Obras Psicológicas Completas de Sigmund Freud, Editora Imago, Rio de Janeiro, 1980.

Projeto para uma psicologia científica (1950 [1895]); in.: Edição Standard Brasileira das Obras Psicológicas Completas de Sigmund Freud, Editora Imago, Rio de Janeiro, 1980.

A interpretação dos sonhos (1900); in.: Edição Standard Brasileira das Obras Psicológicas Completas de Sigmund Freud, Editora Imago, Rio de Janeiro, 1980.

Três ensaios sobre a teoria da sexualidade (1905); in.: Edição Standard Brasileira das Obras Psicológicas Completas de Sigmund Freud, Editora Imago, Rio de Janeiro, 1980.

Análise de uma fobia em um menino de cinco anos (1909); in.: Edição Standard Brasileira das Obras Psicológicas Completas de Sigmund Freud, Editora Imago, Rio de Janeiro, 1980.

. Um tipo especial de escolha de objeto feita pelos homens - Contribuições à psicologia do amor I (1910); in.: Edição standard Brasileira das Obras Psicológicas Completas de Sigmund Freud, Editora Imago, Rio de Janeiro, 1980. 
A dinâmica da transferência (1912); in.: Edição Standard Brasileira das Obras Psicológicas Completas de Sigmund Freud, Editora Imago, Rio de Janeiro, 1980.

Sobre a tendência universal à depreciação na esfera do amor - Contribuições à psicologia do amor II (1912); in.: Edição standard Brasileira das Obras Psicológicas Completas de Sigmund Freud, Editora Imago, Rio de Janeiro, 1980.

Totem e tabu (1913 [1912-3]); in.: Edição Standard Brasileira das Obras Psicológicas Completas de Sigmund Freud, Editora Imago, Rio de Janeiro, 1980.

Sobre o narcisismo: uma introdução (1914); in.: Edição Standard Brasileira das Obras Psicológicas Completas de Sigmund Freud, Editora Imago, Rio de Janeiro, 1980.

. História de uma neurose infantil (1918 [1914]); in.: Edição Standard Brasileira das Obras Psicológicas Completas de Sigmund Freud, Editora Imago, Rio de Janeiro, 1980.

. Os instintos e suas vicissitudes (1915); in.: Edição Standard Brasileira das Obras Psicológicas Completas de Sigmund Freud, Editora Imago, Rio de Janeiro, 1980.

O 'estranho' (1919); in.: Edição Standard Brasileira das Obras Psicológicas Completas de Sigmund Freud, Editora Imago, Rio de Janeiro, 1980.

Além do princípio do prazer (1920); in.: Edição Standard Brasileira das Obras Psicológicas Completas de Sigmund Freud, Editora Imago, Rio de Janeiro, 1980.

Psicologia de grupo e análise do ego (1921); in.: Edição Standard Brasileira das Obras Psicológicas Completas de Sigmund Freud, Editora Imago, Rio de Janeiro, 1980.

A cabeça de medusa (1940 [1922]); in.: Edição Standard Brasileira das Obras Psicológicas Completas de Sigmund Freud, Editora Imago, Rio de Janeiro, 1980.

O problema econômico do masoquismo (1924); in.: Edição Standard Brasileira das Obras Psicológicas Completas de Sigmund Freud, Editora Imago, Rio de Janeiro, 1980.

A questão da análise leiga (1926); in.: Edição Standard Brasileira das Obras Psicológicas Completas de Sigmund Freud, Editora Imago, Rio de Janeiro, 1980.

Dostoievski e o parricídio (1928 [1927]); in.: Edição standard Brasileira das Obras Psicológicas Completas de Sigmund Freud, Editora Imago, Rio de Janeiro, 1980.

O mal-estar na civilização (1930 [1929]); in.: Edição Standard Brasileira das Obras Psicológicas Completas de Sigmund Freud, Editora Imago, Rio de Janeiro, 1980.

Novas conferências introdutórias sobre psicanálise (1932 [1931]); in.: Edição Standard Brasileira das Obras Psicológicas Completas de Sigmund Freud, Editora Imago, Rio de Janeiro, 1980. 
A divisão do ego nos processos de defesa (1914 [1938]); in.: Edição Standard Brasileira das Obras Psicológicas Completas de Sigmund Freud, Editora Imago, Rio de Janeiro, 1980.

GAMWELL, L. \& SOLMS, M. Da Neurologia à Psicanálise - desenhos neurológicos e diagramas da mente por Sigmund Freud. Iluminuras Editora; São Paulo; Brasil; 2008.

GARCIA-ROZA, L.A. Introdução à metapsicologia freudiana 1 - sobre as afasias, o projeto de 1895. Jorge Zahar Editor; Rio de Janeiro; Brasil; 1991.

Introdução à metapsicologia freudiana 2 - a interpretação dos sonhos. Jorge Zahar Editor; Rio de Janeiro; Brasil; 1993.

Introdução à metapsicologia freudiana 3 - Artigos de metapsicologia:

narcisismo, pulsão, recalque, inconsciente. Jorge Zahar Editor; Rio de Janeiro; Brasil; 1995.

GAY, P. Freud - uma vida para o nosso tempo. Editora Companhia das Letras, São Paulo, Brasil, 2005.

GOFFMAN, E. Manicômios, prisões e conventos. Editora perspectiva, São Paulo, Brasil, 1999.

GOLDENBERG, R. Política e Psicanálise. Jorge Zahar Editor; Rio de Janeiro; Brasil; 2006.

HANNS, L. A Teoria Pulsional na Clínica de Freud; Editora Imago, Rio de Janeiro, 1999. . Dicionário comentado do alemão de Freud; Editora Imago, Rio de Janeiro, 1996.

HOUAISS, Instituto. Dicionário Houaiss da Língua Portuguesa; Editora Objetiva, Rio de Janeiro, 2001.

LACAN, J. O Seminário - Livro 1 - os escritos técnicos de Freud, Jorge Zahar Editor, Rio de Janeiro, 1986.

. O Seminário - Livro 2 - o eu na teoria de Freud e na técnica da psicanálise, Jorge Zahar Editor, Rio de Janeiro, 1985. Janeiro, 1999.

O Seminário - Livro 5, as formações do inconsciente, Jorge Zahar Editor, Rio de . O Seminário - Livro 7, a ética da psicanálise, Jorge Zahar Editor, Rio de Janeiro, 1988.

. O Seminário - Livro 8, a transferência, Jorge Zahar Editor, Rio de Janeiro, 1992.

O Seminário - Livro 10, a angústia, Jorge Zahar Editor, Rio de Janeiro, 2005.

O Seminário - Livro 11, os quatro conceitos fundamentais da psicanálise, Jorge Zahar Editor, Rio de Janeiro, 1985. 
. O Seminário - Livro 18, de um discurso que não fosse semblante, Jorge Zahar Editor, Rio de Janeiro, 2009.

. O Seminário - Livro 20, mais, ainda, Jorge Zahar Editor, Rio de Janeiro, 1985.

. O estádio do Espelho como formador das funções do eu - Comunicação feita ao XVI Congresso Internacional de Psicanálise, Zurique, 17 de julho de 1949; in.: Escritos, Jorge Zahar Editor, Rio de Janeiro,1998.

A instância da letra no inconsciente ou a razão desde Freud, in.: Escritos, Jorge Zahar Editor, Rio de Janeiro, 1998.

. Subversão do sujeito e dialética do desejo no inconsciente freudiano, in.: Escritos, Jorge Zahar Editor, Rio de Janeiro, 1998.

. Problemas cruciais da psicanálise - resumo do seminário de 1964-65 (1966); in. Outros Escritos, Jorge Zahar Editor, Rio de Janeiro, 2003.

Editor, Rio de Janeiro, 2003.

...ou pior - Relatório do Seminário de 1971 - 72; in. Outros Escritos, Jorge Zahar . O aturdito; in. Outros Escritos, Jorge Zahar Editor, Rio de Janeiro, 2003.

. Radiofonia; in.: Outros Escritos, Jorge Zahar Editor, Rio de Janeiro, 2003.

. Televisão; Jorge Zahar Editor, Rio de Janeiro, 1993.

. Televisão; in.: Outros Escritos, Jorge Zahar Editor, Rio de Janeiro, 2003.

Nomes-do-pai, Jorge Zahar Editor, Rio de Janeiro, 2005.

LAFONT, J. A topologia de Jacques Lacan. Jorge Zahar Editor, Rio de Janeiro, Brasil, 1990.

LAURENT, E. Alienação e separação I; in.: FELDSTEIN et al. Para ler o Seminário 11 de Lacan; Jorge Zahar Editor, Rio de Janeiro, 1997.

LAURENT, E. Alienação e separação II; in.: FELDSTEIN et al. Para ler o Seminário 11 de Lacan; Jorge Zahar Editor, Rio de Janeiro, 1997.

LECOEUR, B. O homem embriagado - estudos psicanalíticos sobre toxicomania $e$ alcoolismo. Editoda FHEMIG, Belo Horizonte, Brasil, 1992.

MILLER, G. The mating mind - how sexual choise shaped the evolution of human nature. Anchorbooks, New York, United States of America, 2000.

MORRIS, D. O macaco nu - um estudo do animal humano. Editora Record, Rio de Janeiro, Brasil, 2004. 
2005.

. A mulher nua - um estudo do corpo da mulher. Editora Globo, São Paulo, Brasil,

OLIVEIRA, J. Freud \& as teorias pré-analíticas do aparelho psíquico. FAFICH/UFMG, Belo Horizonte, Brasil, 1999.

PALAHNIUK, C. Clube da luta. Ed. Leya, São Paulo, Brasil. 2002. (publicação original em 1996).

PELLEGRINO, H. Pacto Edípico e Pacto Social, http://www.sppsic.org.br/blog/?p=354

PINKER, S. O instinto da Linguagem. Editora Martins Fontes, São Paulo,Brasil, 2004.

. Como a mente funciona. Editora Companhia das Letras, São Paulo, Brasil,

2008.

. Os anjos bons da nossa natureza - porque a violência diminuiu. Editora

Companhia das Letras; São Paulo; Brasil; 2011.

PORGE, E. Freud/Fliess - mito e quimera da auto-análise. Jorge Zahar Editor, Rio de Janeiro, Brasil, 1998.

QUINET, A. A descoberta do inconsciente - do desejo ao sintoma. Jorge Zahar Editor; Rio de Janeiro; Brasil; 2003.

. Psicose e laço social - esquizofrenia, paranóia e melancolia. Jorge Zahar Editor; Rio de Janeiro; Brasil; 2006.

A estranheza da psicanálise - a Escola de Lacan e seus analistas; Jorge Zahar Editor; Rio de Janeiro; Brasil; 2009.

RABINOVICH, D. Clínica da Pulsão - as impulsões. Companhia de Freud Editora, Rio de Janeiro, Brasil, 2004.

REALE, M. Lições preliminares de direito; Editora Saraiva, São Paulo, Brasil, 1998.

SANTIAGO, J. A droga do toxicômano - uma parceria cínica na era da ciência. Jorge Zahar Editor; Rio de Janeiro; Brasil; 2001.

SAUSSURE, F. Curso de linguística geral; Editora Cultrix, São Paulo, 1996.

SOLER, C. Variáveis do fim da análise; Editora Papirus, Campinas, SP, 1995.

O sujeito e o Outro I; in.: FELDSTEIN et al. Para ler o Seminário 11 de Lacan;

Jorge Zahar Editor, Rio de Janeiro, 1997.

O sujeito e o Outro II; in.: FELDSTEIN et al. Para ler o Seminário 11 de Lacan; Jorge Zahar Editor, Rio de Janeiro, 1997. 
O que Lacan dizia das mulheres; Jorge Zahar Editor, Rio de Janeiro, 2006.

STRAUSS, M. O corpo sexuado do parlêtre. In: STYLUS: Revista de psicanálise, $\mathrm{n}^{\circ} 20$, Edição Associação dos Fóruns do Campo Lacaniano, Rio de Janeiro, Brasil, 2010.

TEIXEIRA, A. Um ensaio psicanalítico sobre as toxicomanias e sua relação com o sujeito do inconsciente. Dissertação de Mestrado, Universidade de Brasília, Brasília, Brasil, 2006. 